Cover Photo: Aerial view of Hobbs Brook Reservoir, eastern Massachusetts, looking north, with Winter Street in the foreground and Route 128/Interstate 95 to the right of the reservoir.

Photo by Joseph R. Melanson, Aero Photo, Inc., Wareham, Mass. 
U.S. Department of the Interior

U.S. Geological Survey

\section{Factors Affecting Reservoir and Stream-Water Quality in the Cambridge, Massachusetts, Drinking-Water Source Area and Implications for Source-Water Protection}

By MARCUS C. WALDRON and GARDNER C. BENT

Water-Resources Investigations Report 00-4262

Prepared in cooperation with the

CITY OF CAMBRIDGE, MASSACHUSETTS, WATER DEPARTMENT

Northborough, Massachusetts

2001 


\section{U.S. DEPARTMENT OF THE INTERIOR}

GALE A. NORTON, Secretary

U.S. GEOLOGICAL SURVEY

Charles G. Groat, Director

The use of trade or product names in this report is for identification purposes only and does not constitute endorsement by the U.S. Government.

For additional information write to:

Chief, Massachusetts-Rhode Island District

U.S. Geological Survey

Water Resources Division

10 Bearfoot Road

Northborough, MA 01532

or visit our web site at

http://ma.water.usgs.gov
Copies of this report can be purchased from:

U.S. Geological Survey

Branch of Information Services

Box 25286

Denver, CO 80225-0286 


\section{CONTENTS}

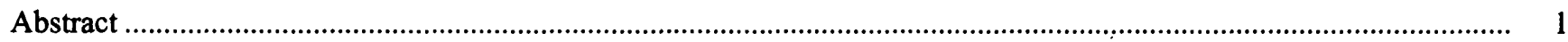

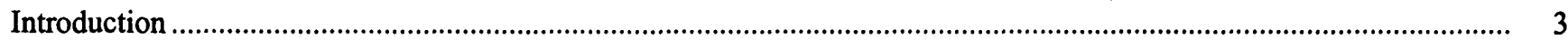

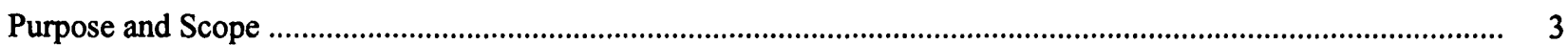

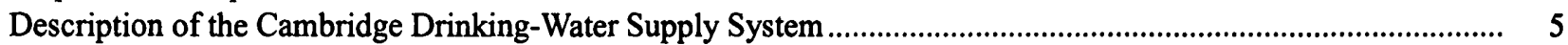

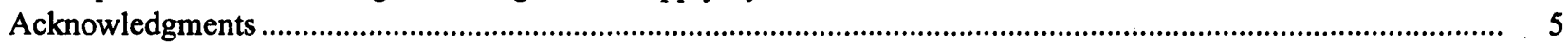

Water Quality and Trophic State of Hobbs Brook Reservoir, Stony Brook Reservoir and Fresh Pond.............................. 6

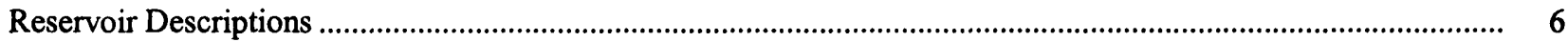

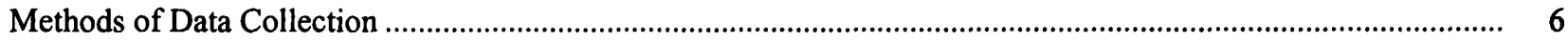

Reservoir Sampling .............................................................................................................................. 7

Sample Preparation and Analysis ......................................................................................................... 7

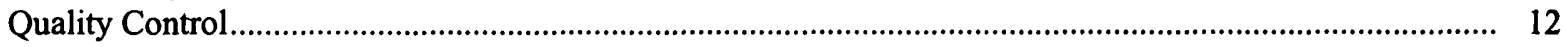

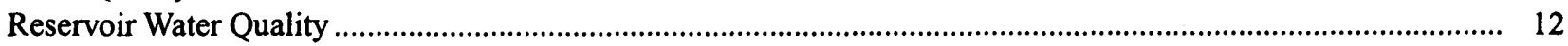

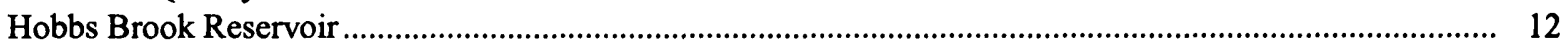

Stony Brook Reservoir ................................................................................................................ 13

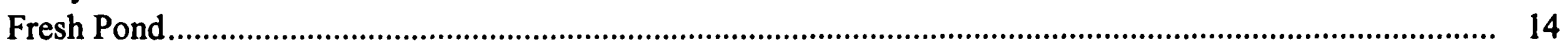

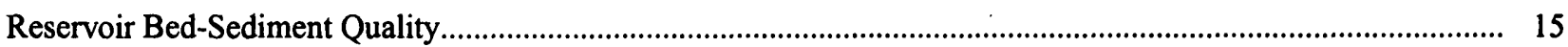

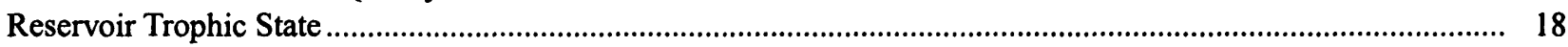

Effects of Drainage-Basin Characteristics on Water Quality of Tributary Streams ........................................................... 19

Description of Sampling Network and Subbasin Characteristics ...................................................................... 19

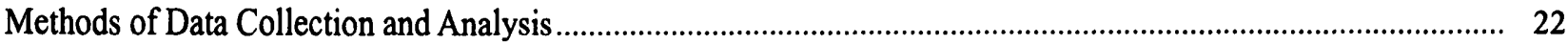

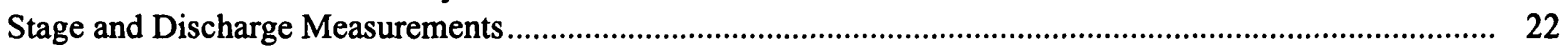

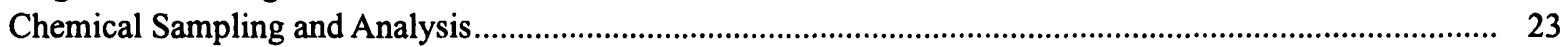

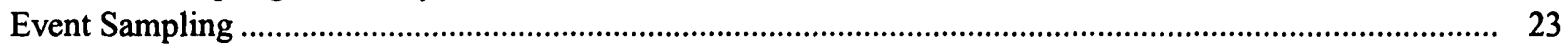

Loading Calculations................................................................................................................................ 23

Constituent Concentrations, Estimated Loads, and Subbasin Yields .................................................................. 25

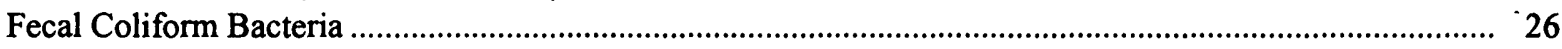

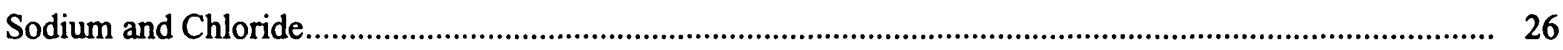

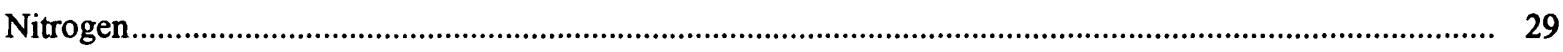

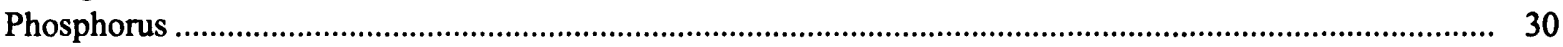

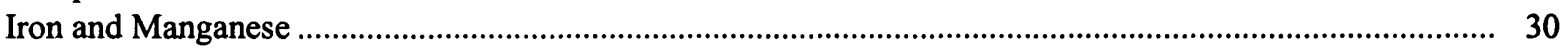

Dissolved Organic Carbon and Trihalomethane Formation Potential...................................................... 31

Constituent Yields in Relation to Subbasin Characteristics ................................................................................ 31

Water and Constituent Mass Balances for Hobbs Brook Reservoir ........................................................................ 33

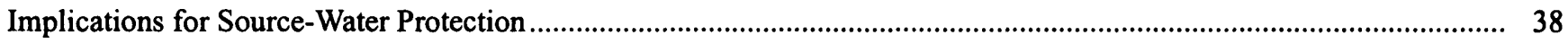

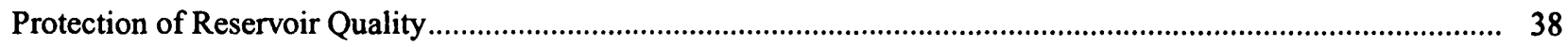

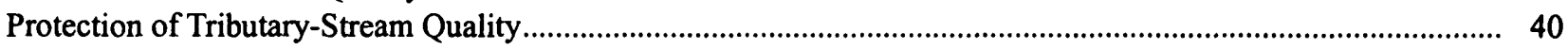

Hobbs Brook at Mill Street near Lincoln, MA (01104405) …........................................................... 40

Cambridge Reservoir, Unnamed Tributary 1, near Lexington, Mass. (01104410) ...................................... 40

Cambridge Reservoir, Unnamed Tributary 2, near Lexington, Mass. (01 104415) ......................................... 40

Cambridge Reservoir, Unnamed Tributary 3, near Lexington, Mass. (01 104420) ......................................... 41

Hobbs Brook, Unnamed Tributary 1, near Kendal Green, Mass. (01104433) ................................................. 41

Hobbs Brook at Kendal Green, Mass. (01104440) .............................................................................. 41

Stony Brook at Kendal Green, Mass. (01104390) …................................................................................ 41

Stony Brook, Unnamed Tributary 1, near Waltham, Mass. (01104455) ....................................................... 42

Stony Brook at Route 20 near Waltham, Mass. (01104460) ................................................................. 42

Stony Brook Reservoir, Unnamed Tributary 1, near Weston, Mass. (01104475) ........................................ 42

Summary and Conclusions........................................................................................................................................ 43

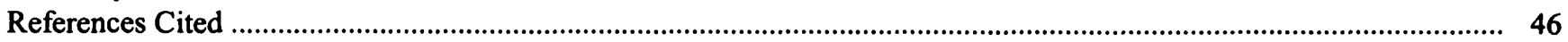


Appendix A. Cambridge, Mass., Drinking-Water Source Area Water Quality Monitoring Program ................................ 81

Monitoring Objectives ................................................................................................................................... 83

Monitoring-Program Elements................................................................................................................................ 83

Routine (Dry Weather) Surface-Water Monitoring ……...................................................................................... 83

Event-Based (Wet Weather) Surface-Water Monitoring .............................................................................. 88

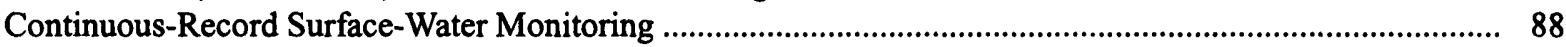

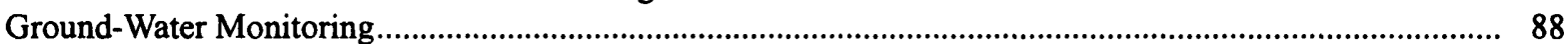

Data Management, Imterpretation, Reporting, and Review ................................................................ 89

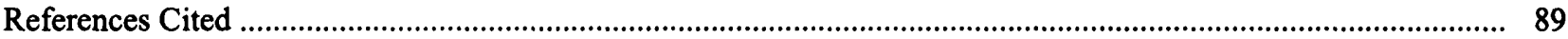

\section{FIGURES}

1-2 Maps showing:

1. Location, extent, and components of the city of Cambridge drinking-water supply system, eastern Massachusetts

2. Bathymetry of $(A)$ Hobbs Brook Reservoir, $(B)$ Stony Brook Reservoir, and $(C)$ Fresh Pond .................... $\quad 9$

3-5. Graphs showing:

3. Depth profiles of temperature and concentrations of dissolved oxygen, nutrients, and other constituents during the 1997-98 study period at the deep hole station in Hobbs Brook Reservoir...

4. Depth profiles of temperature and concentrations of dissolved oxygen, nutrients and other constituents during the 1997-98 study period at the deep hole station in Stony Brook Reservoir

5. Depth profiles of temperature and concentrations of dissolved oxygen, nutrients, and other constituents during the 1997-98 study period at the deep hole station in Fresh Pond

6. Hydrography, subbasin boundaries, and streamflow and water-quality monitoring stations in the Cambridge, Massachusetts, drinking-water source area.

7. Graphs showing concentrations of selected chemical constituents detected at eleven monitoring stations in subbasins that contribute water to Hobbs Brook and Stony Brook Reservoirs, September 1997 November 1998

A1. Cambridge, Mass., drinking water source-area water-quality monitoring network

\section{TABLES}

1. Concentrations of selected trace metals and other contaminants in surficial bed sediments of Hobbs

Brook Reservoir and Stony Brook Reservoir, eastern Massachusetts, November 1998, and median. concentrations of the same analytes in surficial sediments at 135 U.S. Geological Survey sampling sites in the lower Charles River, Boston, Massachusetts, summer 1998

2. Concentrations (normalized to aluminum concentrations) of selected trace metals and other contaminants in surficial bed sediments of Hobbs Brook Reservoir and Stony Brook Reservoir, November 1998, and median normalized concentrations of the same analytes in surficial sediments at 135 U.S. Geological Survey sampling sites in the lower Charles River, Boston, Massachusetts, summer 1998

3. Median Secchi disk transparency, surface chlorophyll- $a$ and total phosphorus concentrations, and trophic state indices derived from those measurements for Hobbs Brook Reservoir, Stony Brook Reservoir, and Fresh Pond, eastern Massachusetts, September 1997-November 1998

4. Names, locations, and drainage areas of monitoring stations used to assess tributary-stream quality in the drinking-water source area for Cambridge, Massachusetts

5. Land use and land cover, topography, and surficial geology in subbasins that contribute water to Hobbs Brook and Stony Brook Reservoirs, eastern Massachusetts ....

6. Ranges and median values for selected physical and chemical characteristics of water in the drinkingwater source area for Cambridge, Massachusetts, October 1997-November 1998, in relation to Massachusetts source-water and Federal drinking-water standards

7. Median instantaneous loads and yields of fecal coliform bacteria and estimated annual mean loads and subbasin yields of selected chemical constituents during water year 1998 (October 1997 through September 1998) for subbasins that contribute water to Hobbs Brook and Stony Brook Reservoirs, eastern Massachusetts. 
8. Product moment correlation coefficients $(r)$ relating percent areal coverage of subbasin characteristics to estimated annual mean yields (mass per unit area) of ten potential contaminants in subbasins of the drinking-water source area for Cambridge, Massachusetts, October 1997-September 1998

9. Water balance for Hobbs Brook Reservoir, October 1997-September 1998

10. Mass balances for dissolved sodium, total nitrogen, total phosphorus, and dissolved manganese for Hobbs Brook Reservoir, eastern Massachusetts, October 1997-September 1998

A1. Water sources, sampling frequencies, and monitored water-quality properties and constituents, for water-quality monitoring stations in the drinking-water source area for Cambridge, Massachusetts.

\section{CONVERSION FACTORS, VERTICAL DATUM, AND ABBREVIATED WATER-QUALITY UNITS}

\section{CONVERSION FACTORS}

\begin{tabular}{rrl}
\hline Multiply & By & To obtain \\
\hline cubic meter per second $\left(\mathrm{m}^{3} / \mathrm{s}\right)$ & 35.3107 & cubic foot per second \\
kilogram per day $(\mathrm{kg} / \mathrm{d})$ & 2.2046 & pound per day \\
kilograms per day per square kilometer $\left(\mathrm{kg} / \mathrm{d} / \mathrm{km}^{2}\right)$ & .8512 & pound per day per square mile \\
kilogram per year $(\mathrm{kg} / \mathrm{yr})$ & 2.2046 & pound per year \\
kilometer $(\mathrm{km})$ & .6215 & mile \\
liter $(\mathrm{L})$ & .2642 & gallon \\
meter $(\mathrm{m})$ & 3.2808 & foot \\
millimeter $(\mathrm{mm})$ & 0.0394 & inch \\
square kilometer $\left(\mathrm{km}^{2}\right)$ & .3861 & square mile
\end{tabular}

Temperature is given in degrees Celsius $\left({ }^{\circ} \mathrm{C}\right)$, which can be converted to degrees

Fahrenheit $\left({ }^{\circ} \mathrm{F}\right)$ by use of the following equation: ${ }^{\circ} \mathrm{F}=\left(1.8 \times{ }^{\circ} \mathrm{C}\right)+32$

\section{VERTICAL DATUM}

Sea level: In this report, "sea level" refers to the National Geodetic Vertical Datum of 1929 (NGVD of 1929)-a geodetic datum derived from a general adjustment of the first-order level nets of the United States and Canada, formerly called Sea Level Datum of 1929.

Cambridge datum: Bathymetric contours are given as elevations, in feet, and are referenced to the city of Cambridge datum, which is 10.84 feet below mean sea level.

\section{ABBREVIATED WATER-QUALITY UNITS}

Chemical concentration is given in grams per liter $(\mathrm{g} / \mathrm{L})$, milligrams per liter $(\mathrm{mg} / \mathrm{L})$, or micrograms per liter $(\mu \mathrm{g} / \mathrm{L})$. Milligrams per liter is a unit expressing the concentration of chemical constituents in solution as weight (milligrams) of solute per unit volume (liter) of water. One thousand milligrams per liter is equivalent to one gram per liter. One thousand micrograms per liter is equivalent to one milligram per liter. For concentrations less than $7,000 \mathrm{mg} / \mathrm{L}$, the numerical value is the same as for concentrations in parts per million. Specific conductance of water is expressed in microsiemens per centimeter at 25 degrees Celsius $(\mu \mathrm{S} / \mathrm{cm})$. This unit is equivalent to micromhos per centimeter at 25 degrees Celsius $(\mu \mathrm{mho} / \mathrm{cm})$, formerly used by the U.S. Geological Survey. 


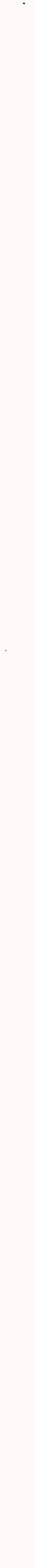




\title{
Factors Affecting Reservoir and Stream-Water Quality in the Cambridge, Massachusetts, Drinking-Water Source Area and Implications for Source-Water Protection
}

\author{
By Marcus C. Waldron and Gardner C. Bent
}

\begin{abstract}
This report presents the results of a study conducted by the U.S. Geological Survey, in cooperation with the city of Cambridge, Massachusetts, Water Department, to assess reservoir and tributary-stream quality in the Cambridge drinkingwater source area, and to use the information gained to help guide the design of a comprehensive water-quality monitoring program for the source area. Assessments of the quality and trophic state of the three primary storage reservoirs, Hobbs Brook Reservoir, Stony Brook Reservoir, and Fresh Pond, were conducted (September 1997-November 1998) to provide baseline information on the state of these resources and to determine the vulnerability of the reservoirs to increased loads of nutrients and other contaminants. The effects of land use, land cover, and other drainage-basin characteristics on sources, transport, and fate of fecal-indicator bacteria, highway deicing chemicals, nutrients, selected metals, and naturally occurring organic compounds in 11 subbasins that contribute water to the reservoirs also was investigated, and the data used to select sampling stations for incorporation into a water-quality monitoring network for the source area.
\end{abstract}

All three reservoirs exhibited thermal and chemical stratification, despite artificial mixing by air hoses in Stony Brook Reservoir and Fresh Pond. The stratification produced anoxic or hypoxic conditions in the deepest parts of the reservoirs and these conditions resulted in the release of ammonia nitrogen orthophosphate phosphorus, and dissolved iron and manganese from the reservoir bed sediments.

Concentrations of sodium and chloride in the reservoirs usually were higher than the amounts recommended by the U.S. Environmental Protection agency for drinking-water sources (20 milligrams per liter for sodium and 250 milligrams per liter for chloride). Maximum measured sodium concentrations were highest in Hobbs Brook Reservoir (113 milligrams per liter), intermediate in Stony Brook Reservoir (62 milligrams per liter), and lowest in Fresh Pond (54 milligrams per liter). Bed sediments in Hobbs Brook and Stony Brook Reservoirs were enriched in iron, manganese, and arsenic relative to those in the impounded lower Charles River in Boston, Massachusetts.

Trophic state indices, calculated for each reservoir based on nutrient concentrations, watercolumn transparency, and phytoplankton abundances, indicated that the upper and middle basins of Hobbs Brook Reservoir were moderately to highly productive and likely to produce algal blooms; the lower basin of Hobbs Brook Reservoir and Stony Brook Reservoir were similar and intermediate in productivity, and Fresh Pond was relatively unproductive and unlikely to produce algal blooms. This pattern is likely due to sedimentation of organic and inorganic particles in the three 
basins of Hobbs Brook Reservoir and in Stony Brook Reservoir. Molar ratios of nitrogen to phosphorus ranged from 55 in Stony Brook Reservoir to 120 in Hobbs Brook Reservoir, indicating that phytoplankton algae in these water bodies may be phosphorus limited and therefore sensitive to small increases in phosphorus loading from the drainage basin. Nitrogen loads were found to be less important than phosphorus to the trophic condition of the reservoirs.

Hobbs Brook and Stony Brook, the two principle streams draining the Cambridge drinkingwater source area, differed in their relative contributions to many of the estimated constituent loads. The estimated load of fecal coliform bacteria was more than seven times larger for the mainly residential Stony Brook subbasin upstream from Kendal Green, Mass., than it was for the more commercial and industrial Hobbs Brook subbasin, though the drainage areas of the two subbasins differ only by about 20 percent. The State standard for fecal coliform bacteria in streams in the Cambridge drinking-water source area ( 20 colony forming units per 100 milliliters) was exceeded at all sampling stations.

Estimated subbasin yields for sodium and chloride were significantly correlated with the percentage of the subbasin area occupied by roads, indicating that the application of sodium chloride in road salt is a significant source of the high concentrations of sodium measured in the reservoirs. The estimated annual mean loads of sodium and chloride produced by the Hobbs Brook subbasin were about three times greater than those produced by the Stony Brook subbasin.

The Hobbs Brook and Stony Brook subbasins produced similar estimated loads for nitrate nitrogen and total nitrogen. Subbasin yields of the two nitrogen species also were similar. In contrast, the estimated total phosphorus load at the mouth of Hobbs Brook was nearly twice that at the Stony Brook station.

The Hobbs Brook and Stony Brook subbasins produced similar estimated annual mean loads for iron. However, the estimated annual mean manganese load from the Hobbs Brook subbasin was about three times greater than that from the
Stony Brook subbasin. Estimated annual mean yields for iron were greatest at stations representing the upper Hobbs Brook subbasins; those for manganese were greatest at the two stations downstream from Hobbs Brook Reservoir.

Both concentrations and yields of dissolved organic carbon were correlated with percent areal coverage of forested wetland in the subbasins. Neither concentrations nor yields of trihalomethane formation potential could be correlated with subbasin features such as land use, land cover, slope, or surficial geology. Concentrations of trihalomethane formation potential were similar to those reported in the literature for surface-water supplies in other parts of the country. Estimated annual mean yields of dissolved organic compound and trihalomethane formation potential were uniform, suggesting that no subbasin was exporting a disproportionate amount of either constituent on an annual basis.

The mass balance for water in Hobbs Brook Reservoir indicated that the time required for complete flushing of the reservoir during water year 1998 was less than 6 months. Sodium accumulated during the water year as the reservoir refilled following an unusually dry summer. The reservoir retained much of the nitrogen and phosphorus contributed by tributary streams. Waterfowl and precipitation were insignificant as sources of nitrogen to the reservoir but may have been important as sources of phosphorus.

Based on the results obtained from these investigations, ten stream locations were selected for inclusion as primary tributary-monitoring stations in a source-area water-quality monitoring network developed jointly by the U.S. Geological Survey and the Cambridge Water Department. Criteria for inclusion in the network were the magnitudes of actual or potential contaminant loads and the proximity of the monitoring stations to the reservoirs. In addition, nine monitoring stations representative of water-quality and trophic conditions in Hobbs Brook Reservoir, Stony Brook Reservoir, and Fresh Pond were identified and incorporated into the network. Details of the monitoring network are included in an appendix to this report. 


\section{INTRODUCTION}

Water-quality monitoring is a critical element of any program designed to manage and protect drinkingwater supplies. Water-quality monitoring in this context is defined as "an integrated activity for evaluating the physical, chemical, and biological character of water in relation to human health, ecological conditions, and designated water uses" (Intergovernmental Task Force on Monitoring Water Quality, 1995). A water-quality management program includes the monitoring of streams, lakes, reservoirs, and ground-water resources that serve as primary sources for drinking water, and also may be extended to wetlands, atmospheric deposition, and surface runoff that contribute water to the primary source. Without accurate and timely information on the state of the water supply, effective preservation and remediation programs cannot be accomplished, and the effectiveness of the management program cannot be evaluated.

Increased development in and around source areas is affecting many of the Nation's drinking-water supplies. Often it is impossible or impractical for a municipal water department to purchase and control all of the land that contributes to the water supply, and ongoing development of private property carries a risk of adding to contaminant loads from a variety of sources. Existing water-quality monitoring programs, however, frequently were established at a time when development pressures were not as great as they are currently (2000), and often they are either inadequate or not as cost-effective as they could be (Reinelt and others, 1988).

The U.S. Geological Survey (USGS) works closely with municipal water suppliers throughout the Nation to help address specific problems or to conduct detailed investigations of factors affecting source-water quality (Patterson, 1997). One such program, begun in 1997 in cooperation with the city of Cambridge, Mass., was designed to identify sources of contaminants in the drinking-water source area for the city (fig. 1). The Cambridge Water Department (CWD) supplies about 57 million liters of water each day to more than 95,000 customers. Most of this water is obtained from a system of reservoirs located in Cambridge and in parts of five other suburban Boston communities. The drainage basin that contributes water to these reservoirs has undergone rapid development in recent years and contains major highways, secondary roads, and areas of residential, commercial, and industrial land uses that could adversely affect the water supply. Because the city of Cambridge owns less than 5 percent of the land in the basin, the CWD relies heavily on water-quality monitoring to ensure that the source water remains free from contamination.

The goals of the USGS investigation were to characterize current water-quality conditions in the drinking-water source area, to identify tributaries with the greatest potential for transporting contaminants to the reservoirs, and to provide baselines for contaminant loads that may be used to evaluate the effectiveness of watershed best-management practices. Although water treatment can remove many contaminants, it is usually better and more cost effective to prevent contamination of the water supply. There is growing recognition of the value of protecting the high-quality waters that are a source of drinking water as a means of reducing the cost of treatment systems required under the Safe Drinking Water Act (New England Interstate Water Pollution Control Commission, 1996; U.S. Environmental Protection Agency, 1998).

\section{Purpose and Scope}

The purpose of this report is to describe current water-quality conditions in the Cambridge, Mass., drinking-water source area and to use this information to identify tributaries and other sampling sites that should be monitored as part of a comprehensive source-water protection program. The first part of the report is a limnological assessment of the three primary storage reservoirs in the system, Hobbs Brook Reservoir, Stony Brook Reservoir, and Fresh Pond. The assessment, conducted during a 14-month period (September 1997-November 1998), includes information on water and sediment quality, and an evaluation of the vulnerability of the reservoirs to eutrophication. The second part of the report presents the results of a concurrent investigation of the effects of land use, land cover, and other drainage-basin characteristics on transport and fate of highway deicing chemicals, nutrients, naturally occurring organic compounds, fecalindicator bacteria, and selected trace metals within the source area. The third part of the report uses the information gained in the two investigations to identify reservoir and tributary-monitoring sites that are representative of source-water quality and can be used to account for potentially significant sources of contaminants in the area. A brief description of a water-quality monitoring program, designed jointly by the USGS and the CWD to address water-quality problems identified in the report, is included as an appendix. 


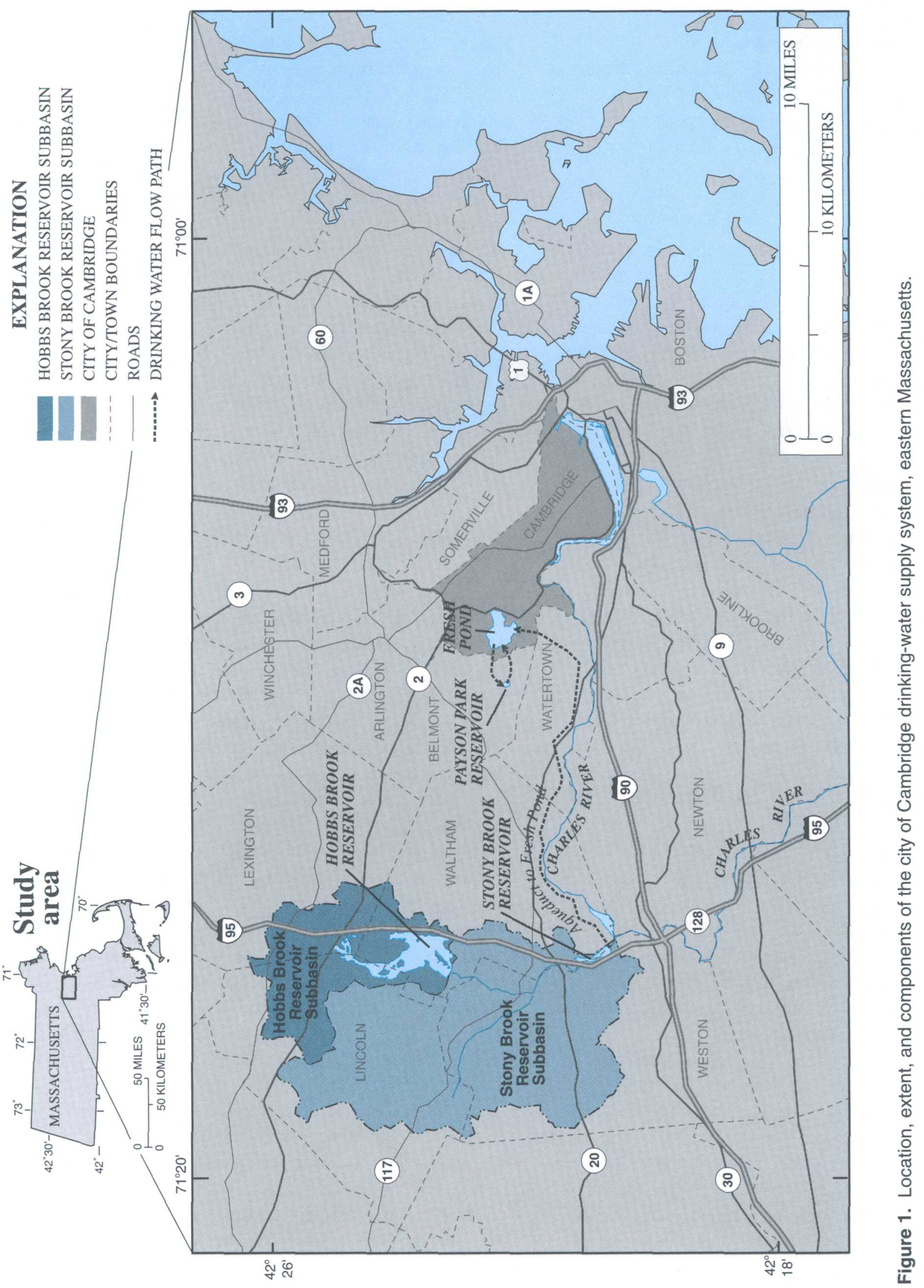




\section{Description of the Cambridge Drinking-Water Supply System}

Cambridge, Mass., is a city of about 95,000 permanent residents and more than 60,000 university students. The drinking-water supply system currently consists of Hobbs Brook and Stony Brook Reservoirs, which drain a $61.4 \mathrm{~km}^{2}$ basin in Lexington, Lincoln, Waltham, and Weston, Mass., and Fresh Pond, a glacial kettle-hole lake located in Cambridge (fig. 1).

Hobbs Brook Reservoir is known locally as the "Cambridge Reservoir," and is designated as such on the USGS 1:25,000-scale topographic quadrangle for Maynard, Mass. The drainage basin for the reservoir includes Hobbs Brook and three unnamed tributaries that discharge directly into the reservoir. Additional water enters the reservoir through other unnamed tributaries, storm drains associated with State Routes 2 and 128 (Interstate-95), secondary roads, and commercial parking lots. Water is discharged from the dam at the lower end of Hobbs Brook Reservoir into Hobbs Brook, which joins Stony Brook about $2 \mathrm{~km}$ downstream. Stony Brook Reservoir is fed by Stony Brook, one tributary, and by storm drains from State Routes 128 and 20. The CWD pipes water through an aqueduct from Stony Brook Reservoir to Fresh Pond, where it is stored prior to treatment. After treatment the finished water is pumped to Payson Park Reservoir in Belmont, Mass., then flows by gravity through a 306-kilometer long distribution system. Overflow from Stony Brook Reservoir flows into the Charles River in Waltham, Mass.

The primary source area for the water supply varies seasonally. During periods of high flow (mainly winter and spring), water from the upper Hobbs Brook drainage basin is used to fill Hobbs Brook Reservoir, and most of the water that is pumped to Fresh Pond comes from the larger Stony Brook drainage basin. During periods of low flow (mainly summer and autumn), the contribution from Stony Brook decreases considerably, and most of the water supply comes from releases from Hobbs Brook Reservoir.

Major water-quality concerns in the source area are higher-than-desired concentrations of dissolved sodium, iron, manganese, and dissolved organic carbon (DOC) in the reservoirs, and the potential for accelerated reservoir eutrophication arising from surface-water and ground-water inflows of nitrogen and phosphorus. Sodium, a component of road-deicing salt, is of concern because it persists in treated drinking water and increases consumers' dietary intake of sodium. Manganese derived mainly from natural sources in the drainage basin occasionally appears in the finished water at concentrations exceeding the U.S. Environmental Protection Agency's secondary maximum contaminant level (SMCL) of $50 \mu \mathrm{g} / \mathrm{L}$. Problems associated with manganese are mainly aesthetic, such as discoloring of laundry and plumbing fixtures (Hem, 1985). High concentrations of DOC are undesirable because some natural organic materials react with chlorine during water treatment to form a variety of potentially hazardous by-products, the most common of which is chloroform, a trihalomethane compound (Reckhow and others 1990). The propensity of source water to form these compounds is measured as trihalomethane formation potential (THMFP). Nitrogen and phosphorus, which may enter the water supply from nonpoint sources such as precipitation, bank erosion, fertilizer, waterfowl, and stormwater runoff, can stimulate excessive algal growth, causing increased turbidity, depletion of dissolved oxygen, and mobilization of contaminants from reservoir sediments (Cooke and others, 1993).

\section{Acknowledgments}

The authors wish to thank Timothy MacDonald, Manager of Water Operations, Edward Dowling, Water Quality Supervisor, and Chip Norton, Watershed Manager, Cambridge Water Department, for their help in planning and facilitating this study and for providing analyses of dissolved organic carbon, trihalomethane formation potential, and fecal coliform bacteria. We also thank Dave Velasco and Karen Zalieckas, for assisting in the field work and data management. Additional support for this study was provided by the Massachusetts Highway Department. Henry Barbaro and Samuel Pollack helped in facilitating this support. 


\section{WATER QUALITY AND TROPHIC STATE OF HOBBS BROOK RESERVOIR, STONY BROOK RESERVOIR, AND FRESH POND}

Assessments of the quality and trophic state of Hobbs Brook Reservoir, Stony Brook Reservoir, and Fresh Pond were conducted to provide baseline information on the state of these resources in support of the CWD's water-quality monitoring program. Representative sampling stations were established on the three reservoirs and sampling for physical, chemical, and biological characteristics was carried out over a period of 14 months. The data were used to characterize the extent of vulnerability of the reservoirs to increased loads of nutrients and other contaminants and to help establish a reservoir monitoring protocol for inclusion in the water-quality monitoring program. Data on nutrient concentrations, water-column transparency, and phytoplankton abundance were used to calculate trophic state indices for each of the reservoirs. Reservoir bed sediments were examined once at the end of the study period for the presence of some trace metals and other constituents.

\section{Reservoir Descriptions}

Hobbs Brook Reservoir drains an area of $17.8 \mathrm{~km}^{2}$ and has a surface area of $2.4 \mathrm{~km}^{2}$ when full (fig. $2 A$ ). The reservoir is divided into upper, middle, and lower basins by State Route 2 and Trapelo Road. Water flows between the three basins through unregu- lated submerged culverts. Except for periods of extreme low flow, water elevation in the three basins is essentially the same. The reservoir's storage capacity is about $9,000,000 \mathrm{~m}^{3}$ (Fugro East, Inc., 1996). Mean depth at full capacity is $3.8 \mathrm{~m}$.

Stony Brook Reservoir drains an area of $61.4 \mathrm{~km}^{2}$ and has a maximum surface area of about $0.3 \mathrm{~km}^{2}$ (fig. $2 B$ ). The narrow, steep-sided reservoir has a storage capacity of about $1,200,000 \mathrm{~m}^{3}$ and is divided into two basins by State Route 128. Mean depth at full capacity is about $4.4 \mathrm{~m}$ (Fugro East, Inc., 1996).

Fresh Pond is a glacial kettle-hole lake with no natural surface-water inputs or outputs (fig. $2 C$ ). Water from Stony Brook Reservoir flows through an aqueduct into Fresh Pond at a rate designed to minimize groundwater inflows to the pond (Fugro East, Inc., 1996). The maximum surface area of Fresh Pond is $0.63 \mathrm{~km}^{2}$ and its maximum storage volume is $5,400,000 \mathrm{~m}^{3}$. Both Fresh Pond and Stony Brook Reservoir are artificially mixed during the spring, summer, and autumn months by an aeration system that bubbles air from tubes lying on the bottoms of the reservoirs.

\section{Methods of Data Collection}

Water-quality sampling stations were established over the deepest points in Hobbs Brook Reservoir (fig. 2A), Stony Brook Reservoir (fig $2 B$ ), and Fresh Pond (fig. 2C). Additional sampling stations were established at the downstream ends of the middle and upper basins of Hobbs Brook Reservoir (fig. $2 A$ ). 


\section{Reservoir Sampling}

At intervals ranging from 4 to 13 weeks, beginning in late September 1997 and continuing through November 1998, depth profiles of water temperature, dissolved oxygen, $\mathrm{pH}$, and specific conductance were measured at each of the deepwater sampling stations using a Hydrolab multiparameter water-quality monitoring system. Measurement intervals for the depth profiles were $1 \mathrm{~m}$ for Hobbs and Stony Brook Reservoirs and $2 \mathrm{~m}$ for Fresh Pond. Secchi disk transparency also was measured and water samples collected for determination of chlorophyll- $a$ concentration (an indicator of phytoplankton biomass) and concentrations of major ions, nitrogen and phosphorus species, and dissolved iron and manganese. Concentrations of DOC and THMFP were measured, but at less frequent intervals than the other constituents. The water samples were pumped through clean Tygon tubing from a depth of $2 \mathrm{~m}$ if the water column was isothermal, or from three depths $-0.5 \mathrm{~m}$ below the surface, the depth of the thermocline (the point of maximum rate of change in water temperature with depth), and 0.25 to $0.5 \mathrm{~m}$ above the bottom-if the water column was thermally stratified. Water from each sampling depth was collected using clean sampling protocols (Wilde and others, 1999) into 3-liter Teflon bottles for chemical determinations and into 1-liter opaque, polyethylene bottles for chlorophyll- $a$ determinations.

Samples of surficial bed sediments were collected once in November 1998 at the deepest points in each of the three Hobbs Brook Reservoir Basins and at the deep hole in Stony Brook Reservoir. Duplicate samples representing about $0.1 \mathrm{~m}^{3}$ were collected at each station with a stainless-steel Ekman dredge.

\section{Sample Preparation and Analysis}

Samples were placed in a cooler and returned to shore where they were prepared as required for each of the chemical and biological determinations. Chlorophyll- $a$ samples were filtered onto glass-fiber filters, which were then dried in the dark for 30 minutes at room temperature (Godfrey and Kerr, 2000). Samples for dissolved nutrient species, major ions, and metals determinations were filtered through $0.45 \mu \mathrm{m}$ capsule filters into polyethylene bottles and chilled or acidified as required. Samples for DOC determinations were filtered through $0.45 \mu \mathrm{m}$ silver filters into baked brown-glass bottles using a stainless-steel filtration system. The samples then were stored on ice prior to analysis. Samples for determination of THMFP were dispensed into 1-liter baked brown glass bottles and stored on ice pending analysis.

Spectrophotometric chlorophyll- $a$ analyses (American Public Health Association and others, 1995) were performed by the Environmental Analytical Laboratory at the University of Massachusetts in Amherst. DOC and THMFP determinations were conducted by the CWD laboratory in Cambridge. Analysis of DOC was by wet oxidation with infrared spectroscopic carbon dioxide detection (American Public Health Association and others, 1995). 


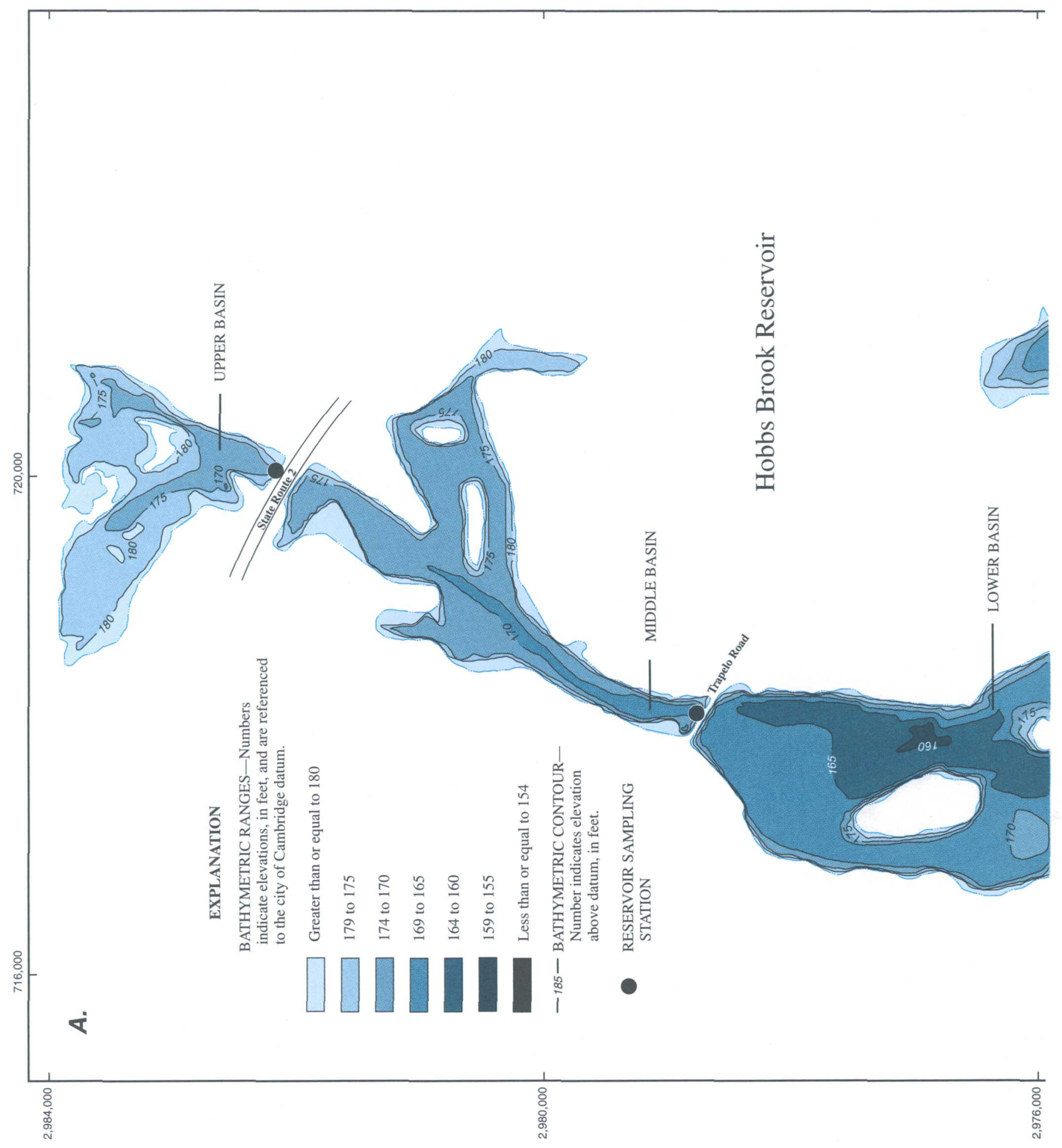




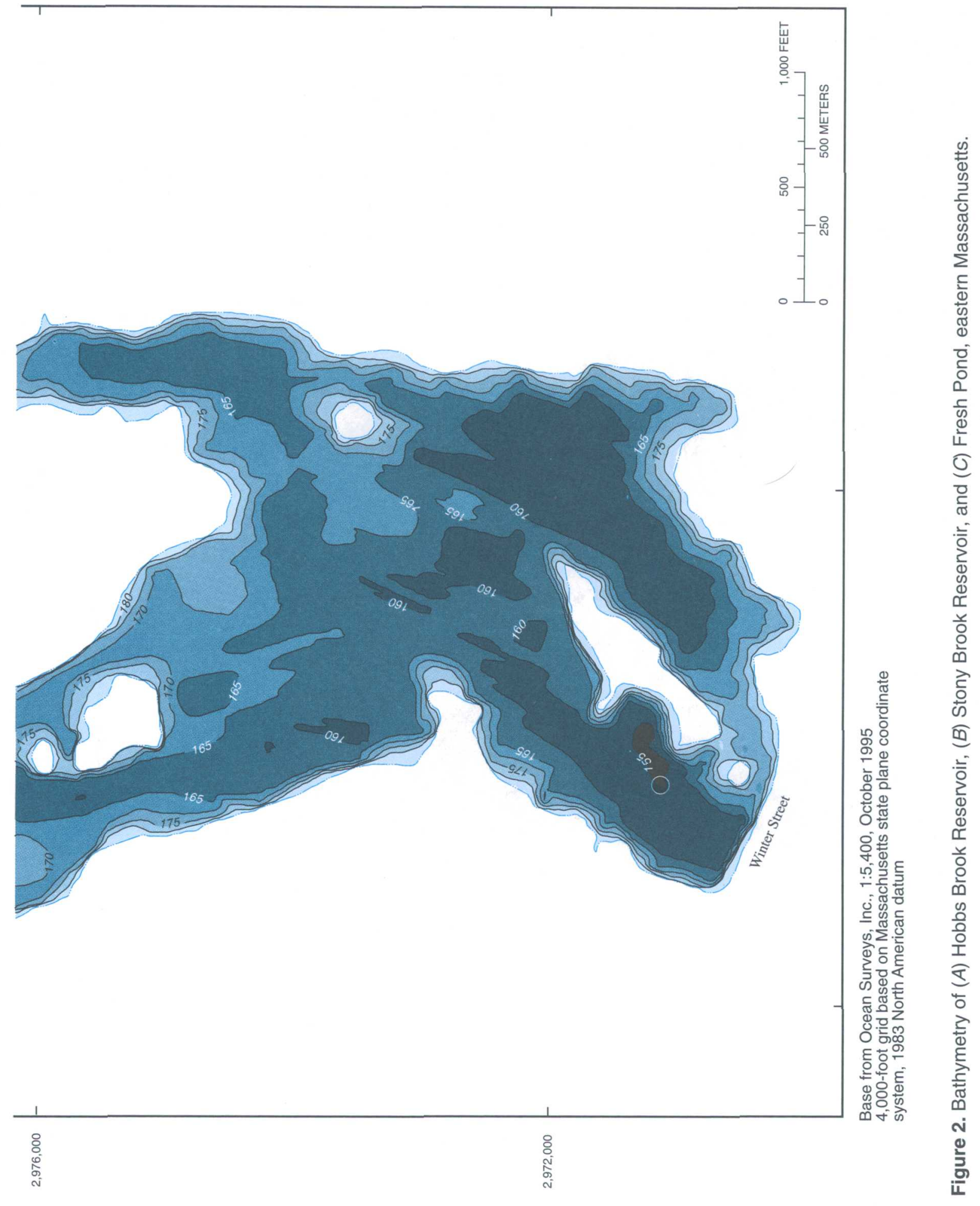




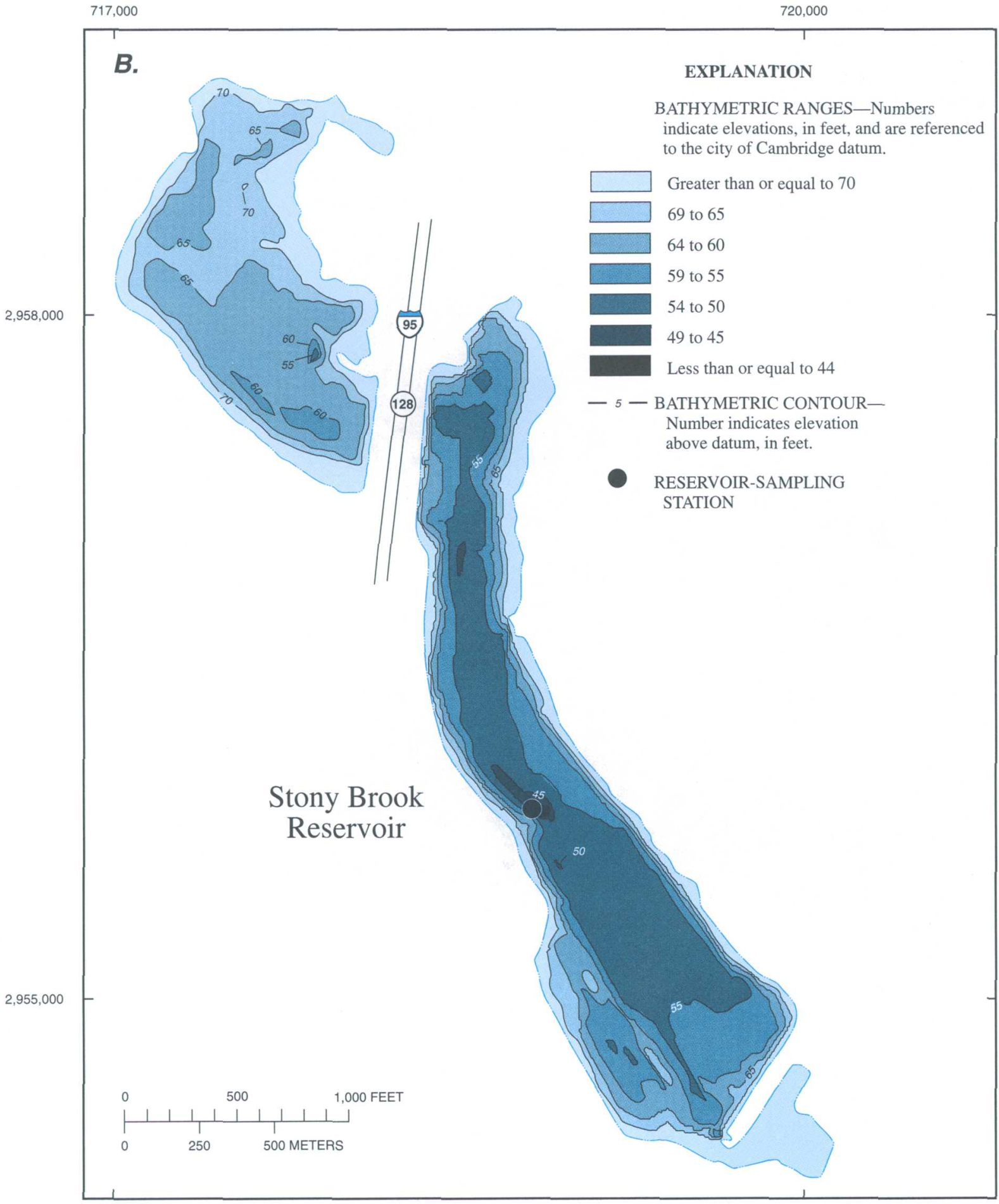

Base from Ocean Surveys, Inc., 1:5,400, October 1995

4,000-foot grid based on Massachusetts state plane coordinate system, 1983 North American datum

Figure 2. Bathymetry of $(A)$ Hobbs Brook Reservoir, $(B)$ Stony Brook Reservoir, and $(C)$ Fresh Pond, eastern Massachusetts-Continued. 


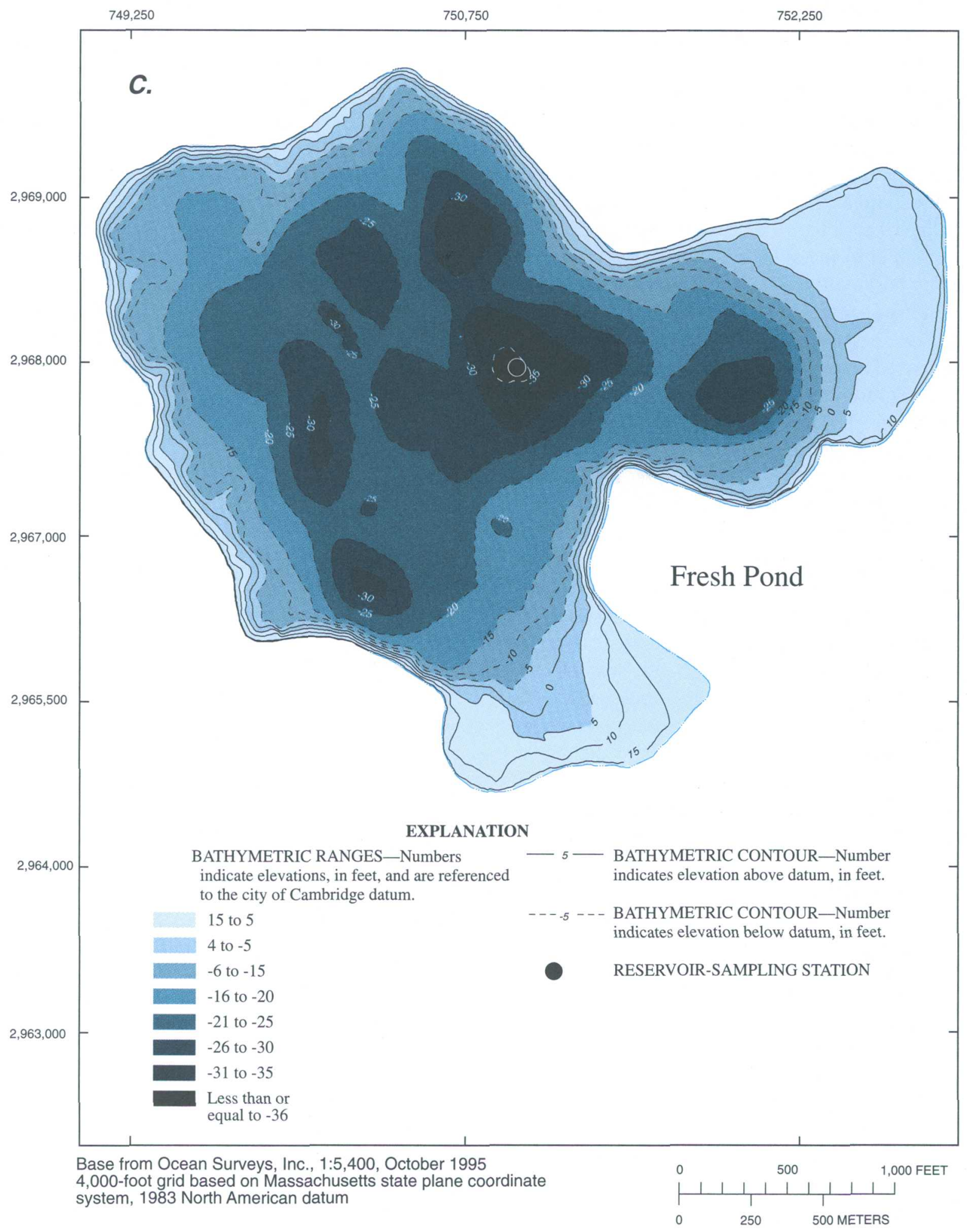

Figure 2. Bathymetry of $(A)$ Hobbs Brook Reservoir, $(B)$ Stony Brook Reservoir, and $(C)$ Fresh Pond, eastern Massachusetts-Continued. 
Trihalomethane formation potential was measured as the sum of the concentrations of chloroform, bromodichloromethane, dibromochloromethane, and bromoform formed during chlorination of the water sample (American Public Health Association and others, 1995, Method 5710). Chlorine was added to buffered ( $\mathrm{pH}$ 7.0) samples to a final concentration of $10 \mathrm{mg} / \mathrm{L}$ and the samples were incubated for 7 days at $25^{\circ} \mathrm{C}$. Quantification of the halo-organic compounds formed after chlorination and incubation was accomplished by purge-and-trap gas chromatography/mass spectrometry (American Public Health Association and others, 1995, Method 6232). The $10 \mathrm{mg} / \mathrm{L}$ chlorine dose was used to simulate conditions in the Cambridge water-distribution system. Residual free chlorine $\left(\mathrm{Cl}_{2}\right)$ concentrations ranged from 0 to $6.4 \mathrm{mg} / \mathrm{L}$ with a mean value of $0.6 \mathrm{mg} / \mathrm{L}$ and a standard deviation of $1.1 \mathrm{mg} / \mathrm{L}$. Sixteen percent of the samples had no residual free chlorine; thus, analysis of THMFP concentrations may have been underestimated in these samples.

The sediment samples were subsampled so that only portions that had not come in contact with the dredge were retained. The subsamples then were combined, transferred to prelabeled polyethylene bags, and shipped immediately to XRAL Laboratories in Don Mills, Ontario, Canada, where they were digested with aqua regia and analyzed by inductively coupled plasma atomic emission spectrometry for 32 elements.

All other chemical analyses were performed by the USGS National Water Quality Laboratory in Arvada, Colo., based on analytical methods described in Fishman and Friedman (1989) and quality-assurance procedures described by Pritt and Raese (1992).

\section{Quality Control}

During each round of sampling at least one field blank consisting of organic-free or inorganic-free water was submitted for analysis. Nutrient species and metals were never detected in the inorganic field blanks. Small amounts of DOC representing a maximum of 14 percent of the mean sample concentration occasionally were detected in the organic blanks. THMFP in field blanks never exceeded 2 percent of the mean sample concentration.

Twenty sets of duplicate samples were collected at various sampling sites during the study and analyzed separately for DOC by the USGS National Water Quality Laboratory and the CWD analytical laboratory.
Differences between duplicate DOC determinations ranged from 0 to 36 percent with a mean of 4.8 percent. THMFP analyses performed on five sets of duplicate samples by the CWD and a private contract laboratory (Camp, Dresser, and McKee, Inc., Cambridge, Mass.) resulted in percent differences ranging from 0.1 to 7.9 with a mean of 3.6. Twenty-four sets of duplicate chlorophyll- $a$ samples were analyzed during the study period by the University of Massachusetts, Amherst, Environmental Analytical Laboratory. The percent difference between duplicates ranged from 2.6 to 100 with the mean percent difference of 6.8 .

\section{Reservoir Water Quality}

The following sections describe the physical, chemical, and biological changes observed in Hobbs Brook Reservoir, Stony Brook Reservoir, and Fresh Pond during a 14-month period beginning in September 1997 and continuing through November 1998.

\section{Hobbs Brook Reservoir}

Water-quality conditions in the lower basin of Hobbs Brook Reservoir during the study period are shown in figures $3 A-3 H$ (see p. 53). In late November 1997 the water column at the deep hole reservoir-monitoring station was isothermal and exhibited uniform distributions of dissolved oxygen, specific conductance, and pH (fig. 3A). Water samples collected from a depth of $2 \mathrm{~m}$ contained $67 \mathrm{mg} / \mathrm{L}$ dissolved sodium and small amounts of dissolved manganese and total nitrogen. Concentrations of total phosphorus, ammonia nitrogen, and nitrate nitrogen, however, were below the minimum reporting limits $(0.01 \mathrm{mg} / \mathrm{L}, 0.2 \mathrm{mg} / \mathrm{L}$, and $0.05 \mathrm{mg} / \mathrm{L}$, respectively) of the analytical techniques used.

By January 1998, ice covered most of the reservoir. Specific conductance had increased from $428 \mu \mathrm{S} / \mathrm{cm}$ to just over $600 \mu \mathrm{S} / \mathrm{cm}$. Dissolved sodium and total nitrogen concentrations had increased from the November 1997 measurement (fig. 3B) and measurable amounts of total phosphorus, ammonia nitrogen, and nitrate nitrogen were present. The concentration of dissolved manganese remained low (less than $0.2 \mathrm{mg} / \mathrm{L}$ ). 
Concentrations of dissolved sodium remained high (greater than $80 \mathrm{mg} / \mathrm{L}$ ) and were uniformly distributed with depth in early March 1998 (fig. 3C). Specific conductance also remained close to $600 \mu \mathrm{S} / \mathrm{cm}$ throughout the winter and spring. Following ice out in March, there were small amounts of all three nitrogen species present in the water column. Phosphorus, however, was undetectable, and dissolved manganese concentrations remained low. DOC and THMFP concentrations were low ( 3.8 and $0.165 \mathrm{mg} / \mathrm{L}$, respectively) and concentrations of both organic constituents were uniformly distributed with depth.

With the onset of thermal stratification in early June 1998, dissolved oxygen concentrations began to decrease in the bottom layer (fig. $3 D$ ), which resulted in the release of phosphorus and dissolved manganese from bottom sediments. Concentrations of dissolved sodium were unchanged, but the concentration of ammonia nitrogen in the upper $2 \mathrm{~m}$ of the water column increased to $0.82 \mathrm{mg} / \mathrm{L}$. This increase may have resulted from stormwater runoff. By June 5, DOC had increased to $5.4 \mathrm{mg} / \mathrm{L}$ and THMFP had increased to $0.315 \mathrm{mg} / \mathrm{L}$ at the surface. These increases may have been related to a rain storm immediately preceding the sampling, in which more than $4 \mathrm{~cm}$ of rain fell in a 4-day period, following a 2-week dry period.

By late July 1998, the bottom $1 \mathrm{~m}$ of the water column was anoxic with high concentrations of total phosphorus $(0.05 \mathrm{mg} / \mathrm{L})$, ammonia nitrogen $(0.50 \mathrm{mg} / \mathrm{L})$, total nitrogen $(0.83 \mathrm{mg} / \mathrm{L})$, and dissolved manganese $(2,100 \mu \mathrm{g} / \mathrm{L})$ (fig. $3 E$ ). Each of these constituents is mobilized from bottom sediments under anoxic conditions. Nutrient concentrations in the surface layer were low and dissolved sodium concentrations were unchanged. This condition persisted through early August (fig. $3 F$ ). Although there was little change in the distribution of DOC with depth in the water column, by early August the THMFP had decreased to $0.123 \mathrm{mg} / \mathrm{L}$ under anoxic conditions in the bottom layer. This decrease may indicate that the reactive components of the DOC in the bottom layer were degraded under anoxic conditions, or that DOC released from the sediments during stratification exhibited less THMFP than did DOC from terrestrial or water-column sources.

In early September 1998, the anoxic bottom layer of the water column gradually was eroded by nighttime convection and wind-induced surface mixing (fig. $3 G$ ). Phosphorus released from bottom sediments under anoxic conditions appeared in the upper mixed part of the water column. Chlorophyll- $a$ concentrations (not shown) in the lower basin were low throughout the year (from 1.1 to $3.0 \mu \mathrm{g} / \mathrm{L}$ ) and did not appear to respond to the increase in total phosphorus in the surface layers. Where anoxic conditions persisted, the concentration of THMFP remained low relative to the concentration of the upper mixed layer.

Water released from Hobbs Brook Reservoir to Hobbs Brook during 1997-98 was withdrawn primarily from the anoxic bottom layer with some entrainment of the oxic upper layer. This means that during periods of water-column stratification, most of the water discharged to Hobbs Brook below the reservoir was hypoxic and contained relatively high concentrations of total phosphorus, ammonia nitrogen, and manganese, and relatively low concentrations of THMFP. Evidence of this hypoxic condition and constituent concentrations can be seen in the black manganese oxide deposits on the rocks immediately downstream from the dam.

\section{Stony Brook Reservoir}

Water-column sampling at the deep hole station in Stony Brook Reservoir (fig. $2 B$ ) began in September 1997 and continued through November 1998 (figs. 4A$4 G$, see p. 61). Most of the reservoir was artificially destratified during spring and summer 1997 by pumping compressed air through hoses laid along the long axis of the basin. The basin is long and narrow (fig. $2 B$ ), and is substantially flushed whenever storm flows move through it. However, a small deep pocket is present in the middle of the basin, representing no more than 1 percent of the maximum reservoir surface area and 0.5 percent of the maximum reservoir volume. Water in this pocket became isolated in late spring 1998 and was not flushed completely until early November 1998. During the period of lowest flow in late summer, chemical conditions in the deep hole may have affected as much as 30 percent of the total volume of the reservoir. The deep-hole water-column-sampling station was established at this point. However, depth profiles of temperature, dissolved oxygen concentration, $\mathrm{pH}$, and specific conductance also were measured routinely at the dam and at other locations throughout the basin. Conditions in the main body of the reservoir 
always were well represented by conditions in the upper mixed part of the water column at the deep hole station.

At the beginning of the study period (September 25, 1997), the bottom $1.5 \mathrm{~m}$ of the water column at the deep-hole station still was isolated from the main body of the reservoir (fig. $4 A$ ). The deepest $0.5 \mathrm{~m}$ was anoxic and exhibited increases in $\mathrm{pH}$ and specific conductance relative to the upper mixed layer. Concentrations of total nitrogen (3.7 $\mathrm{mg} / \mathrm{L})$ and ammonia nitrogen $(2.3 \mathrm{mg} / \mathrm{L})$ were the highest measured in any of the reservoirs during the study period and the concentration of dissolved manganese $(6.27 \mathrm{mg} / \mathrm{L})$ was the second highest. The long period of reduced flows during summer 1997 apparently produced strongly reducing conditions in the deep hole, which favored the release of these constituents.

By November 1997 the entire water column was mixed, including the deep hole (fig. 4B). Ammonia nitrogen and total phosphorus were undetectable; dissolved sodium and nitrate nitrogen concentrations were moderately high at $51 \mathrm{mg} / \mathrm{L}$ and $0.228 \mathrm{mg} / \mathrm{L}$, respectively; and the concentration of dissolved manganese was low at $0.168 \mathrm{mg} / \mathrm{L}$. The concentration of THMFP at $2 \mathrm{~m}$ was $0.156 \mathrm{mg} / \mathrm{L}$.

In early March 1998, the bottom $1.5 \mathrm{~m}$ of the water column began to exhibit a reduced dissolved oxygen concentration and an increased specific conductance (fig. 4C). All measured constituents were uniformly distributed with depth, however, indicating that the water column was still mixing. Concentrations of nitrate nitrogen were unusually high throughout the water column $(0.548-0.566 \mathrm{mg} / \mathrm{L})$. These were the highest concentrations observed in Stony Brook Reservoir and nearly the highest observed during the entire study. There were significant amounts of nitrate nitrogen entering the reservoir, both from the Stony Brook mainstem $(52 \pm 24 \mathrm{~kg} / \mathrm{d})$ and from a small tributary that enters the reservoir near the dam $(6.5 \pm 2.6 \mathrm{~kg} / \mathrm{d})$, during January through March 1998 .

Thermal and chemical isolation of the deep hole proceeded through spring and summer 1998. There was an increased total phosphorus concentration in the bottom water by late May (fig. $4 D$ ) and similar increases in the concentrations of total nitrogen, ammonia nitrogen, and dissolved manganese by early
August (fig. 4E). As was the case in Hobbs Brook Reservoir, the concentration of THMFP decreased under anoxic conditions in the deep hole at Stony Brook Reservoir, although there was no concurrent decrease in the DOC concentration. In August, the anoxic bottom layer had the highest concentration of total phosphorus $(0.074 \mathrm{mg} / \mathrm{L})$ measured in any of the reservoirs during the study period.

By mid-September 1998, there were increased concentrations of ammonia nitrogen, total nitrogen, and dissolved manganese throughout the lower $4 \mathrm{~m}$ of the water column (fig. $4 F$ ), but by early November, with complete mixing of the water column, concentrations of these constituents had returned to low values (fig. 4G).

\section{Fresh Pond}

Water-column sampling did not begin at the Fresh Pond deep-hole station until October 2, 1997. Conditions at that time reflected the operation of an aeration system similar to that in Stony Brook Reservoir. Sampling results demonstrated that water temperature, dissolved oxygen, $\mathrm{pH}$, and specific conductance were uniformly distributed with depth, as were all other measured constituents (fig. $5 A$, see p. 68). Concentrations of ammonia nitrogen, and dissolved manganese were among the lowest recorded in the study. The water column continued to be well mixed through December 3, 1997 (fig. 5B), and under ice cover in January (fig. 5C). In January the concentration of nitrate nitrogen increased to $0.38 \mathrm{mg} / \mathrm{L}$ and THMFP concentrations ranged from 0.373 to $0.443 \mathrm{mg} / \mathrm{L}$. By March 4, the THMFP concentrations had decreased to $0.159 \mathrm{mg} / \mathrm{L}$ (fig. $5 D$ ). Spring and summer produced few changes in water-column conditions (fig. $5 E$ ), although by late August, the dissolved oxygen concentration near the bottom was reduced to $2.2 \mathrm{mg} / \mathrm{L}$ and dissolved manganese was measured at a concentration of $2.97 \mathrm{mg} / \mathrm{L}$ (fig. $5 F$ ). A single water sample collected in late August from $13.9 \mathrm{~m}$ at another deep hole located about $300 \mathrm{~m}$ north of the main sampling station contained the highest concentration of dissolved manganese $(12.7 \mathrm{mg} / \mathrm{L})$ recorded during the study period. In the absence of complete anoxia, however, THMFP concentrations remained high and uniformly distributed with depth throughout the summer. 
It is possible that manganese is released under hypoxic conditions from various points in the sediments of Fresh Pond in late summer. Fresh Pond has the typical kettle-hole morphometry with four deep holes reflecting the shape of the original melting glacial remnant (fig. 2C). If these deep areas become hypoxic in late summer there is a potential for release of reduced manganese $\left(\mathrm{Mn}^{2+}\right)$ from the sediments into the water column. Once in solution, manganese is slow to reoxidize and can remain in solution for some time under conditions in the pond (Stumm and Morgan, 1970). Manganese also forms soluble complexes with natural organic matter (Hem, 1985). Evidence is available that oxidation (and precipitation) of dissolved manganese in lakewaters is microbially mediated and, therefore, temperature dependent (Tipping, 1984). Thus, manganese released to the water column in late summer and autumn would tend to remain in solution as the water column cooled.

\section{Reservoir Bed-Sediment Quality}

Concentrations of 33 constituents in bed sediments collected in summer 1998, from Hobbs Brook Reservoir and Stony Brook Reservoir, together with median concentrations of the same analytes in bed sediments from 135 sampling sites in the lower Charles River in Boston, Mass., are shown in table 1. The Charles River samples were collected in June and July 1998 and were analyzed by the same laboratory (Breault and others, 2000). Breault and others (2000) give a detailed account of their sampling methods and quality-assurance procedures. Because the Charles River is impounded at its mouth in Boston, it may be regarded as a heavily urbanized reservoir for comparison with Hobbs Brook and Stony Brook Reservoirs.

For many analytes, bed-sediment concentrations in Stony Brook Reservoir were higher than those in Hobbs Brook Reservoir and were either higher than or similar to those recorded in the lower Charles River. The sediment phosphorus concentration in Stony Brook Reservoir was $2.7 \mathrm{~g} / \mathrm{kg}$, three times that of Hobbs Brook Reservoir and Fresh Pond and nearly twice that of the lower Charles River.
Similarly, concentrations of aluminum, arsenic, cobalt, iron, manganese, titanium, and vanadium were appreciably higher in Stony Brook Reservoir sediments than in Hobbs Brook Reservoir, Fresh Pond, the lower Charles River. Concentrations of cadmium, copper, silver, strontium, and zinc were two to four times higher in Stony Brook Reservoir sediments than they were in those of Hobbs Brook Reservoir, but usually were much less abundant than in sediments of the lower Charles River. Stony Brook Reservoir and lower Charles River sediments contained similar amounts of chromium, lead, and nickel, and these were much higher in concentration than in Hobbs Brook Reservoir.

Patterns of enrichment of trace metals and other constituents in the Cambridge Reservoir system and the lower Charles River arise from the interaction of hydrologic features that promote deposition and the presence or absence of local sources. Effects of differential deposition on the observed enrichment patterns were clarified by normalizing elemental concentrations to the concentration of aluminum. Aluminum is associated with fine clay particles and is thought to be relatively conservative with respect to its rate of dissolution from crustal-rock sources (Horowitz, 1991). Consequently, elevated normalized concentrations (above background levels) at a particular site relative to those at another site indicate the possible presence of a nearby source.

Normalized bed-sediment concentrations of most trace elements were lower in the Cambridge Reservoirs than in the lower Charles River (table 2). Exceptions are arsenic, which was about twice as abundant in Hobbs Brook Reservoir as it was in the lower Charles River, and iron and manganese, which were higher in Stony Brook Reservoir than at any other station. Normalized bed-sediment concentrations of cadmium, chromium, copper, lead, nickel, silver, strontium, and zinc in the Cambridge Reservoirs were about half those in the lower Charles River. In contrast, all stations had similar normalized sediment concentrations of calcium, magnesium, sodium, and phosphorus. While there appear to be fewer potential sources of trace metals in the Cambridge drinking-water source area than in the heavily urbanized Boston area, phosphorus sources are similar. 
Table 1. Concentrations of selected trace metals and other contaminants in surficial bed sediments of Hobbs Brook Reservoir and Stony Brook Reservoir, eastern Massachusetts, November 1998, and median concentrations of the same analytes in surficial sediments at 135 U.S. Geological Survey sampling sites in the lower Charles River, Boston, Massachusetts, summer 1998

[Charles River data from Breault and others (2000). MRL, minimum reporting limit. g/kg, grams per kilogram; mg/kg, milligrams per kilogram; <, actual value is less than value shown]

\begin{tabular}{|c|c|c|c|c|c|c|}
\hline \multirow{2}{*}{ Analyte } & \multirow{2}{*}{ MRL } & \multicolumn{3}{|c|}{ Hobbs Brook Reservoir } & \multirow{2}{*}{$\begin{array}{c}\text { Stony Brook } \\
\text { Reservolr } \\
\text { (deep hole) }\end{array}$} & \multirow{2}{*}{$\begin{array}{l}\text { Lower Charles } \\
\text { RIver }\end{array}$} \\
\hline & & Upper basin & Middle basin & Lower basin & & \\
\hline Calcium $(\mathrm{g} / \mathrm{kg})$ & 0.1 & 6.9 & 8.0 & 4.2 & 7.4 & 6.4 \\
\hline Magnesium $(\mathrm{g} / \mathrm{kg})$ & .1 & 3.8 & 4.0 & 3.8 & 10.8 & 5.8 \\
\hline Sodium $(\mathrm{g} / \mathrm{kg})$ & .1 & 0.6 & .5 & .3 & .6 & .7 \\
\hline Potassium $(\mathrm{g} / \mathrm{kg})$ & .1 & 1.2 & 1.3 & .7 & 2.4 & 2.7 \\
\hline Phosphorus $(\mathrm{g} / \mathrm{kg})$ & .1 & .9 & .9 & .9 & 2.7 & 1.6 \\
\hline Aluminum $(\mathrm{g} / \mathrm{kg}) \ldots \ldots \ldots \ldots \ldots \ldots \ldots$ & .1 & 10.7 & 12.4 & 12.2 & 29.0 & 18.1 \\
\hline Antimony $(\mathrm{mg} / \mathrm{kg}) \ldots \ldots \ldots \ldots \ldots$ & 5 & $<5$ & $<5$ & $<5$ & $<5$ & $<5$ \\
\hline Arsenic $(\mathrm{mg} / \mathrm{kg}) \ldots \ldots \ldots \ldots$ & 3 & 5 & 4 & 6 & 14 & 3 \\
\hline 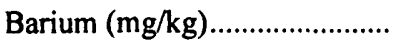 & 1 & 86 & 126 & 67 & 191 & 192 \\
\hline Beryllium (mg/kg)...................... & .5 & $<.5$ & $<.5$ & $<.5$ & $<.5$ & $<.5$ \\
\hline Bismuth $(\mathrm{mg} / \mathrm{kg})$ & 5 & 5 & $<5$ & $<5$ & $<5$ & $<5$ \\
\hline Cadmium (mg/kg)........................ & 1 & $<1$ & 1 & 1 & 3 & 7 \\
\hline Chromium (mg/kg) ..................... & 1 & 18 & 27 & 40 & 104 & 106 \\
\hline 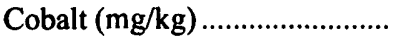 & 1 & 10 & 13 & 15 & 25 & 13 \\
\hline Copper $(\mathrm{mg} / \mathrm{kg})$ & .5 & 23.4 & 54.3 & 22.7 & 81.4 & 270 \\
\hline Iron $(\mathrm{g} / \mathrm{kg})$ & .1 & 20.2 & 22.5 & 18.1 & 71.7 & 31.5 \\
\hline 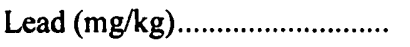 & 2 & 68 & 178 & 90 & 651 & 642 \\
\hline Lanthanum $(\mathrm{mg} / \mathrm{kg})$........................ & .5 & 13.8 & 15.2 & 13.0 & 29.1 & 19.2 \\
\hline 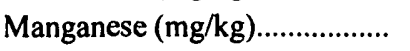 & 2 & 265 & 320 & 256 & 1,100 & 466 \\
\hline Mercury $(\mathrm{mg} / \mathrm{kg})$ & 1 & $<1$ & $<1$ & $<1$ & $<1$ & $<1$ \\
\hline Molybdenum (mg/kg) .............. & 1 & $<1$ & $<1$ & $<1$ & $<1$ & 2 \\
\hline Nickel (mg/kg) ............................. & 1 & 14 & 20 & 19 & 43 & 40 \\
\hline Scandium $(\mathrm{mg} / \mathrm{kg})$............................ & .5 & 2.1 & 2.1 & 2.1 & 6.2 & 3.9 \\
\hline Silver $(\mathrm{mg} / \mathrm{kg})$ & .2 & $<.2$ & $<.2$ & $<.2$ & .6 & 4.2 \\
\hline Strontium (mg/kg)....................... & .5 & 23.5 & 31.0 & 22.0 & 44.1 & 61.5 \\
\hline Tin $(\mathrm{mg} / \mathrm{kg})$ & 10 & $<10$ & $<10$ & $<10$ & $<10$ & $<10$ \\
\hline Titanium $(\mathrm{g} / \mathrm{kg})$ & .1 & .9 & .8 & .9 & 1.6 & .7 \\
\hline 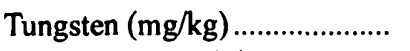 & 10 & $<10$ & $<10$ & $<10$ & $<10$ & $<10$ \\
\hline 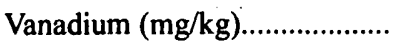 & 2 & 31 & 46 & 50 & 127 & 77 \\
\hline Yttrium (mg/kg) ............................ & .5 & 9.7 & 9.1 & 9.9 & 18.7 & 13 \\
\hline Zinc $(\mathrm{mg} / \mathrm{kg})$ & .5 & 122 & 244 & 149 & 423 & 643 \\
\hline Zirconium $(\mathrm{mg} / \mathrm{kg}) \ldots \ldots \ldots \ldots \ldots$ & .5 & 3.4 & 5.7 & 4.3 & 9.3 & 1.9 \\
\hline Total organic carbon $(\mathrm{g} / \mathrm{kg}) \ldots .$. & .1 & 27.0 & 67.3 & 32.6 & 77.2 & 109 \\
\hline
\end{tabular}


Table 2. Concentrations (normalized to aluminum concentrations) of selected trace metals and other contaminants in surficial bed sediments of Hobbs Brook Reservoir and Stony Brook Reservoir, eastern Massachusetts, November 1998, and median normalized concentrations of the same analytes in surficial sediments at 135 U.S. Geological Survey sampling sites in the lower Charles River, Boston, Massachusetts, summer 1998

[Charles River clata from Breault and others (2000). Analyte concentrations from table 1 are divided by the corresponding aluminum concentration and expressed as a percent. --, no data]

\begin{tabular}{|c|c|c|c|c|c|}
\hline \multirow{2}{*}{ Analyte } & \multicolumn{3}{|c|}{ Hobbs Brook Reservoir } & \multirow{2}{*}{$\begin{array}{l}\text { Stony Brook } \\
\text { Reservolr } \\
\text { (deep hole) }\end{array}$} & \multirow{2}{*}{$\begin{array}{c}\text { Lower } \\
\text { Charles } \\
\text { River }\end{array}$} \\
\hline & Upper basin & Middle basin & Lower basin & & \\
\hline Calcium & 64.5 & 64.5 & 34.4 & 25.5 & 35.4 \\
\hline 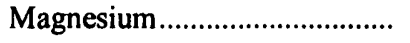 & 35.5 & 32.3 & 31.1 & 37.2 & 32.0 \\
\hline Sodium & 5.6 & 4.0 & 2.5 & 2.1 & 3.9 \\
\hline 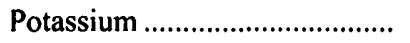 & 11.2 & 10.5 & 5.7 & 8.3 & 14.9 \\
\hline 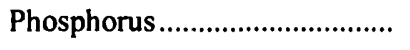 & 8.4 & 7.2 & 7.4 & 9.3 & 8.8 \\
\hline 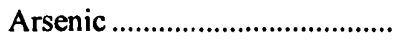 & .05 & .03 & .05 & .05 & .02 \\
\hline 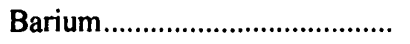 & .80 & 1.0 & .55 & .66 & 1.1 \\
\hline Cadmium & -- & .01 & .01 & .01 & .04 \\
\hline Chromium & .17 & .22 & .33 & .36 & .60 \\
\hline Cobalt & .09 & .11 & .12 & .09 & .07 \\
\hline 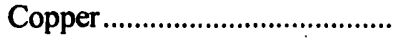 & .22 & .44 & .19 & .28 & 1.5 \\
\hline Iron & 188.8 & 181.5 & 148.4 & 247.2 & 174.0 \\
\hline 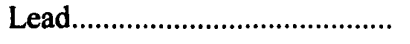 & .64 & 1.4 & .74 & 2.2 & 3.5 \\
\hline 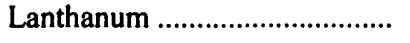 & .13 & .12 & .11 & .10 & .11 \\
\hline Manganese ................................... & 2.5 & 2.6 & 2.1 & 3.8 & 2.6 \\
\hline Nickel ........................................ & .13 & 1.6 & .16 & .15 & .22 \\
\hline 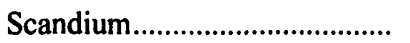 & .02 & .02 & .02 & .02 & .02 \\
\hline Silver & -- & -- & -- & .01 & .02 \\
\hline Strontium & .22 & .25 & .18 & .15 & .34 \\
\hline Titanium & 8.4 & 6.5 & 7.4 & 5.5 & 3.9 \\
\hline 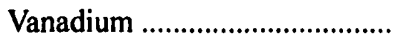 & .29 & .37 & .41 & .44 & .43 \\
\hline 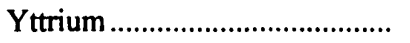 & .09 & .07 & .08 & .06 & .07 \\
\hline Zinc & 1.1 & 2.0 & 1.2 & 1.5 & 3.6 \\
\hline 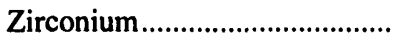 & .03 & .05 & .04 & .03 & .07 \\
\hline
\end{tabular}


Sediment quality of Fresh Pond was investigated in the early 1990s as part of a limnological study of the entire reservoir system (Fugro East, Inc., 1996). Concentrations of phosphorus and manganese were measured in the eastern end of the pond where bed sediments were only minimally affected by alum deposits from the treatment plant. Bed sediments at this site contained $0.45 \mathrm{~g} / \mathrm{kg}$ phosphorus, $4.6 \mathrm{~g} / \mathrm{kg}$ aluminum, and $510 \mathrm{mg} / \mathrm{kg}$ manganese. The values for aluminum and phosphorus were lower than any measured in Hobbs Brook Reservoir, Stony Brook Reservoir, or in the lower Charles River. The manganese concentration, however, is exceeded only by the value recorded in this investigation for Stony Brook Reservoir. Fresh Pond bed sediments may be the source of the occasional high concentrations of dissolved manganese encountered at the water-supply intake.

\section{Reservoir Trophic State}

Carlson's trophic state index (TSI, Carlson, 1977) was used to characterize the extent of eutrophication of the three reservoirs. The TSI is a dimensionless value ranging from 0 to 100 . It may be derived from the mean concentration of phytoplankton chlorophyll $a$ during the summer growing season, the annual mean concentration of total phosphorus, or the annual mean Secchi disk transparency. TSI values between 40 and 50 indicate a moderately productive (mesotrophic) water body with intermediate loading of nutrients and organic matter (Cooke and others, 1993). TSI values less than 40 indicate low productivity (oligotrophic) and minimal external nutrient loading. A TSI greater than 50 corresponds to a chlorophyll- $a$ concentration greater than about $6.4 \mu \mathrm{g} / \mathrm{L}$, a Secchi disk transparency less than about $2 \mathrm{~m}$, and a total phosphorus concentration greater than about $0.024 \mathrm{mg} / \mathrm{L}$. Water bodies in this range are highly productive (eutrophic) and likely to produce algal blooms (Reckhow, 1979). Because the index is a continuous scale it provides a convenient way to compare the three reservoirs and to track changes over time.

TSI values calculated for the Cambridge drinking-water-supply reservoirs ranged from the high 40's in Hobbs Brook Reservoir to a minimum of 27 in Fresh Pond (table 3). Secchi disk measurements were not made in the shallow upper basin of Hobbs Brook Reservoir, so it was not possible to calculate a TSI based on Secchi disk transparency. A single measurement made in the middle basin in September 1998 produced a TSI of 60 , but this may not be representative of conditions throughout the year.

In general, the TSIs decreased with the position of the water body in the drainage basin. The upper and middle basins of Hobbs Brook Reservoir had the highest values (48-50); the lower basin of Hobbs Brook Reservoir and Stony Brook Reservoir were similar and intermediate in value (35-49), and Fresh Pond had the lowest values (27-42). This pattern is due partly to sedimentation of organic and inorganic particles in the three basins of Hobbs Brook Reservoir and in Stony Brook Reservoir. Sedimentation of nutrients and other

Table 3. Median Secchi disk transparency, surface chlorophyll-a, and total phosphorus concentrations, and trophic state indices derived from those measurements, for Hobbs Brook Reservoir, Stony Brook Reservoir, and Fresh Pond, eastern Massachusetts, September 1997-November 1998

[Secchi disk transparency given in meters. Chlorophyll-a concentration given in micrograms per liter. Total phosphorus concentration given in milligrams per liter. TSI (SD), trophic state index calculated from secchi disk transparency; TSI (Chl), trophic state index calculated from chlorophyll-a concentrations; TSI (TP), trophic state index calculated from total phosphorus concentrations; TN:TP, molar ratio of total nitrogen to total phosphorus; number of samples used in calculation is given in parentheses; -- indicates no data]

\begin{tabular}{|c|c|c|c|c|c|c|c|c|c|c|}
\hline \multirow{3}{*}{ 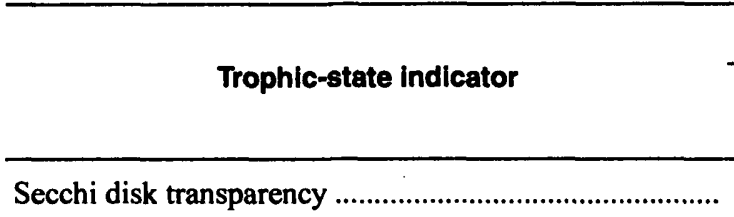 } & \multicolumn{6}{|c|}{ Hobbs Brook Reservolr } & \multirow{2}{*}{\multicolumn{2}{|c|}{$\begin{array}{c}\text { Stony Brook } \\
\text { Reservolr }\end{array}$}} & \multirow{2}{*}{\multicolumn{2}{|c|}{ Fresh Pond }} \\
\hline & \multicolumn{2}{|c|}{$\begin{array}{l}\text { Upper } \\
\text { basin }\end{array}$} & \multicolumn{2}{|c|}{$\begin{array}{l}\text { Middle } \\
\text { basin }\end{array}$} & \multicolumn{2}{|c|}{ Lower basin } & & & & \\
\hline & -- & & 1.0 & (1) & 2.2 & (10) & 2.3 & (8) & 3.4 & (5) \\
\hline Chlorophyll- $a$ concentration & 6.2 & (3) & 6.6 & (4) & 2.1 & $(10)$ & 1.6 & (11) & 1.3 & (7) \\
\hline 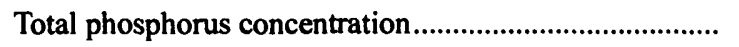 & .024 & (7) & .023 & (8) & .012 & (10) & .010 & (7) & .005 & (6) \\
\hline TSI (SD) & -- & & 60 & (1) & 49 & $(10)$ & 48 & $(8)$ & 42 & (5) \\
\hline TSI (Chl) & 48 & (3) & 49 & (4) & 38 & $(10)$ & 35 & (11) & 33 & (7) \\
\hline TSI (TP) & 50 & (7) & 49 & (8) & 39 & $(10)$ & 41 & $(7)$ & 27 & (6) \\
\hline Mean TN:TP & 74 & (5) & 59 & (5) & 102 & (9) & 55 & (5) & 120 & (2) \\
\hline
\end{tabular}


potential contaminants is an important feature of the Cambridge water-supply system; the water withdrawn from Stony Brook Reservoir likely is of higher quality than it would be in the absence of the three-basin cascade in Hobbs Brook Reservoir upstream.

The annual mean molar ratios of total nitrogen to total phosphorus were calculated for each of the reservoirs to determine which of the two nutrients might be limiting primary production. In inland waters, phosphorus is usually the element in shortest supply relative to its requirement for algal growth (Wetzel, 1993). Because the average molar ratio of nitrogen to phosphorus in algal biomass is about 16 to 1 , a measured ratio greater than 20 to 1 is often considered to be evidence of phosphorus limitation of algal growth and ratios less than 13 to 1 are considered indicative of nitrogen limitation (Cooke and others, 1993). Nitrogen to phosphorus ratios in the Cambridge Reservoir system ranged from 55 in Stony Brook Reservoir to 120 in Fresh pond, indicating that these water bodies may be phosphorus limited. As described by Lee and others (1981), these ratios do not necessarily confirm that a particular nutrient is growth limiting, but only that phosphorus is likely to be the nutrient that will be used up first and become limiting if growth is not limited by light or some other factor. The measured ratios do imply, however, that small increases in phosphorus loading to the reservoirs could stimulate algae to produce blooms, whereas increases in nitrogen probably will not.

\section{EFFECTS OF DRAINAGE-BASIN CHARACTERISTICS ON WATER QUALITY OF TRIBUTARY STREAMS}

Sources of fecal coliform bacteria, dissolved sodium, dissolved chloride, nitrate nitrogen, total nitrogen, total phosphorus, dissolved iron, dissolved manganese, DOC, and THMFP entering Hobbs Brook and Stony Brook Reservoirs were identified and constituent loads were quantified by estimating mean daily loads at key points in the drainage system over a 1-year period. These load estimates then were normalized to the areas of the subbasins defined by the sampling stations and the resultant subbasin yields related statistically to land use, land cover, and other characteristics of the subbasins. The estimated dissolved sodium, total nitrogen, total phosphorus, and dissolved manganese loads were combined with data on stage and bathymetry of Hobbs Brook Reservoir and used to prepare mass balances for these constituents in the reservoir.

One limitation of this approach is the short time period in which the drainage-basin analysis was conducted. Water year 1998 (Oct. 1, 1997-September 30, 1998) was dryer than normal. During calendar year 1997, the National Weather Service observation station at Bedford, Mass., less than $3 \mathrm{~km}$ north of the study area, received 1,004 $\mathrm{mm}$ of precipitation, $133 \mathrm{~mm}$ less than the 30-year normal (National Oceanic and Atmospheric Administration, 1998). The monthly departure from normal from May 1997 through July 1997 and from September 1997 through December 1997 was negative. Precipitation for 1998 was above normal, due largely to a $233 \mathrm{~mm}$ positive departure from the monthly normal in June 1998.

\section{Description of Sampling Network and Subbasin Characteristics}

In 1997, as part of a study designed to identify sources of sodium, calcium, and chloride to the reservoirs, the USGS, in cooperation with the CWD and the Massachusetts Highway Department (MassHighway), established eight stations in the drainage basin, seven equipped for continuous monitoring of stream stage and temperature-compensated specific conductance and one manually sampled (partial-record) station. The continuous-record stations were located on Hobbs Brook, upstream from Hobbs Brook Reservoir, on the three unnamed tributaries to Hobbs Brook Reservoir, on Hobbs Brook at the outlet of the reservoir and just upstream from its confluence with Stony Brook, and on Stony Brook upstream from Stony Brook Reservoir near the intersection of State Route 20 and State Route 128 (Interstate-95) (fig. 6, see p. 74). The partial-record station was located on Stony Brook just upstream from its confluence with Hobbs Brook.

In April 1998, the USGS and the CWD installed one additional continuous-record monitoring station on a small unnamed tributary draining a moderately sloped and heavily developed area along State Route 128 (fig. 6). Additional partial-record stations were established on an unnamed tributary that enters Hobbs Brook between Hobbs Brook Reservoir and the Stony Brook confluence, and on an unnamed tributary that enters Stony Brook Reservoir near the Stony Brook 
dam. Most of these stations had been monitored previously by the CWD and were part of their water-quality monitoring network.

The stations in downstream order with both the USGS and the CWD station numbers are listed in table 4. Characteristics of each of the station subbasins in terms of percent areal coverage of 21 land use/land cover categories, minimum, maximum, and mean, slope, and surficial geology are given in table 5. Drainage-basin characteristics were extracted from a Geographic Information System (GIS) developed by the CWD with data from MassGIS, the USGS National Mapping Division, Harvard Design and Mapping, and Boston Edison. Subbasin slopes were derived from digital elevation models (DEMs) at a $1: 24,000$ scale.

The four subbasins that discharge water directly into Hobbs Brook Reservoir drain approximately $9.5 \mathrm{~km}^{2}$, which represents about 61 percent of the Hobbs Brook Reservoir drainage basin exclusive of the mean reservoir surface area (fig. 6). The subbasins are located in moderately to heavily developed suburban areas with small amounts ( $0-18$ percent) of commercial land use and no industrial land use (table 5). The subbasin defined by the upper Hobbs Brook station (station 01104405) is more than 68 percent forested. Land use is about 18 percent low-density residential (lots greater than one-half acre), with no commercial or industrial land. Twenty-two percent of the subbasin is wetland, mostly in the form of a large red maple swamp in the Hobbs Brook headwater area. In contrast, the subbasin defined by station 01104415 is only 16 percent forested and is only a little over 2 percent wetland. Thirty eight percent of the subbasin is medium density residential (lots one-fourth to one-half acre) land.

The upper Hobbs Brook subbasins include parts of three State-maintained highways (State Routes $2,2 \mathrm{~A}$, and 128), three major interchanges, and numerous locally maintained roads (fig. 6). These are some of the most heavily traveled roads in Massachusetts. MassHighway operates a storage depot for highway deicing salt in the station 01104410 subbasin. Although the depot currently is covered and paved, prior to 1996 the salt was stored uncovered on bare ground. Subbasins for stations 01104410 and 01104420 are situated mainly to the east of State Route 128 and parts of the drainages are routed under the highway through culverts.

Downstream from Hobbs Brook Reservoir are two continuous-record stations and one partial-record station. The partial-record station (station 01104433 ) drains a small subbasin with the heaviest concentrations of commercial (22 percent) and industrial (53 percent) land use of the area defined by any of the stations. The area immediately upstream from the station is a small forested wetland representing about 7 percent of the total area of the subbasin. The continuous-record stations are station 01104430, which is located just downstream from the dam and receives only the regulated discharge from Hobbs Brook Reservoir, and station 01104440 , which is located about $2 \mathrm{~km}$ farther downstream at the confluence of Hobbs Brook and Stony Brook at Kendal Green, Mass. (fig. 6).

Table 4. Names, locations, and drainage areas of monitoring stations used to assess tributary-stream quality in the drinking-water source area for Cambridge, Massachusetts

[USGS, U.S. Geological Survey; CWD, Cambridge Water Department; No., number; km², square kilometers; --, not applicable]

\begin{tabular}{|c|c|c|c|}
\hline Station name & $\begin{array}{c}\text { USGS } \\
\text { Station No. }\end{array}$ & $\begin{array}{c}\text { CWD } \\
\text { Station No. }\end{array}$ & $\begin{array}{c}\text { Drainage area } \\
\left(\mathbf{k m}^{2}\right)\end{array}$ \\
\hline 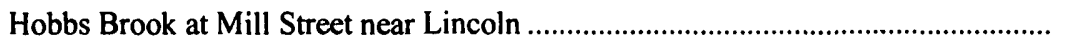 & 01104405 & $\mathrm{HB} 4.50 \mathrm{Cl}+2$ & 5.59 \\
\hline 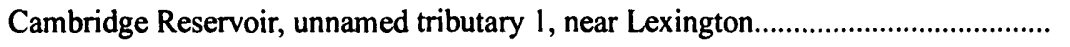 & 01104410 & SDB0.15S & .91 \\
\hline 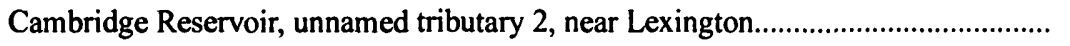 & 01104415 & LB0.01C & 1.06 \\
\hline 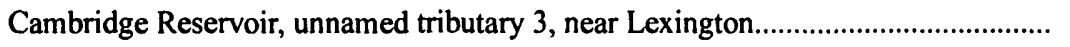 & 01104420 & TL0.30C & 1.89 \\
\hline 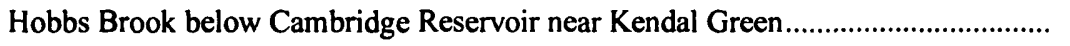 & 01104430 & $\mathrm{HB} 1.60 \mathrm{~S}$ & 17.8 \\
\hline 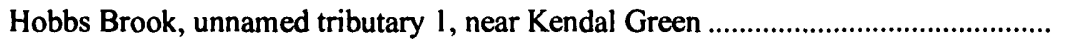 & 01104433 & IB0.05S & 1.08 \\
\hline 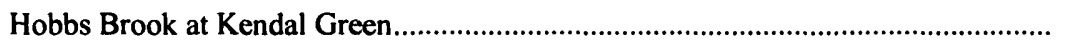 & 01104440 & HB0.05S & 21.9 \\
\hline Stony Brook at Kendal Green & 01104390 & SB2.10S & 26.9 \\
\hline Stony Brook, unnamed tributary 1, near Waltham & 01104455 & -- & 1.2 \\
\hline Stony Brook at Rt. 20 near Waltham & 01104460 & SB1.00S & 57.0 \\
\hline 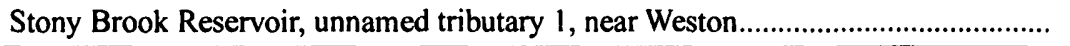 & 01104475 & SS0.10S & 2.2 \\
\hline
\end{tabular}




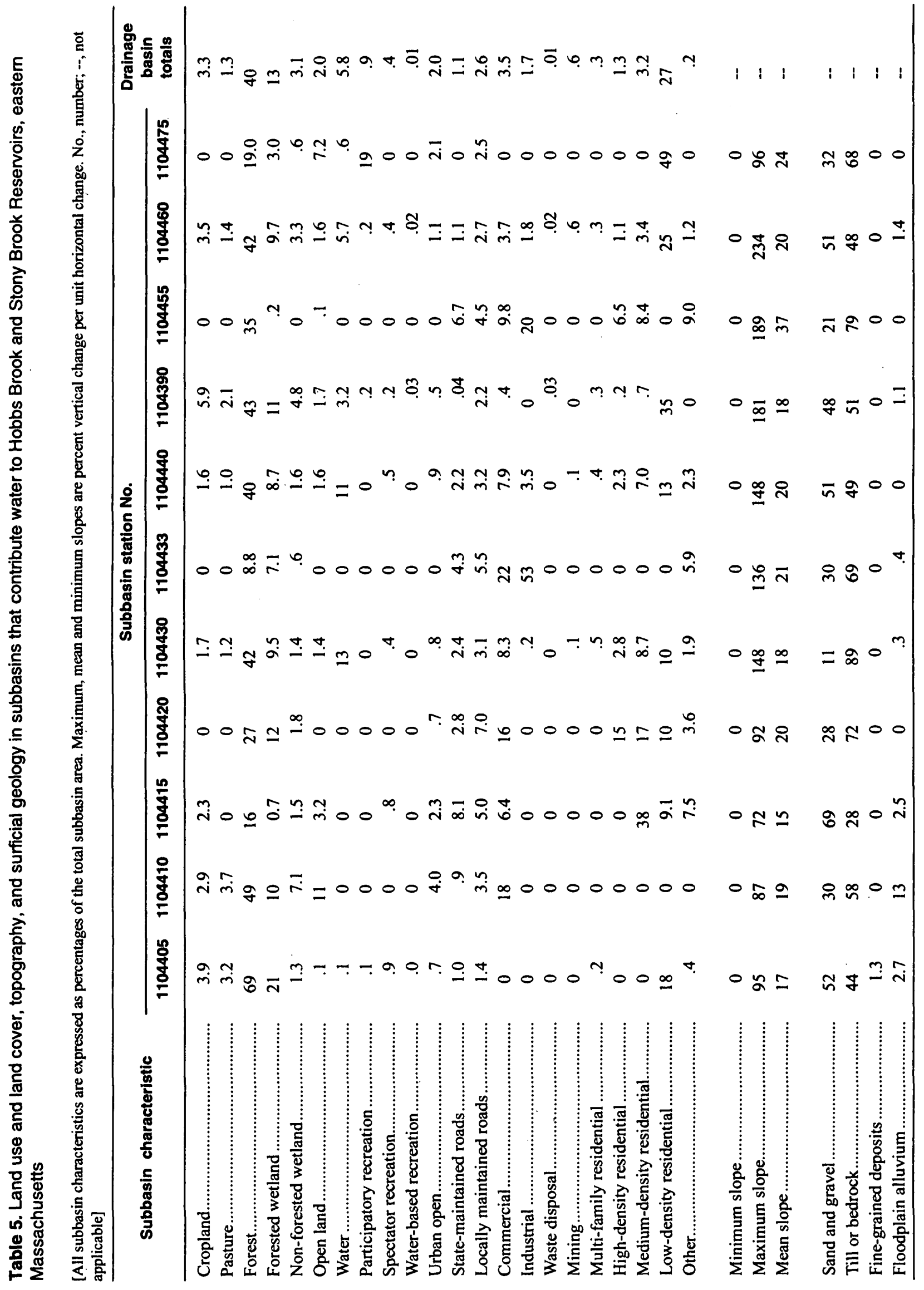


The subbasin defined by the partial-record station on Stony Brook just upstream from the Hobbs Brook confluence (station 01104390 ) drains $26.9 \mathrm{~km}^{2}$ in parts of Lincoln and Weston, Mass., and effectively integrates conditions in that part of the drainage basin (fig. 6). The subbasin is 43 percent forested and about 16 percent is wetland. Little commercial and no industrial land use is present. Nearly 35 percent of the land use in the subbasin is low-density residential; however, the landfill and transfer station for the town of Weston is immediately adjacent to the sampling station. Roads occupy about 2.2 percent of the subbasin, and these roads are predominantly locally maintained. State Routes 117 and a small section of State Route 20 cross the subbasin.

Station 01104455 drains a $1.2 \mathrm{~km}^{2}$ subbasin with a large amount (6.7 percent) of State-maintained roads and large amounts of commercial (9.8 percent) and industrial ( 20 percent) land uses. The monitoring station is located at the opening of a large culvert that runs under State Route 128.

The station on Stony Brook at the intersection of State Routes 20 and 128 (station 01104460 ) includes all of the Hobbs Brook and most of the Stony Brook drainage. Stony Brook enters the upper basin of Stony Brook Reservoir approximately $0.2 \mathrm{~km}$ downstream from the station.

The subbasin defined by station 01104475 contains nearly 50 percent low-density residential land and has no other type of residential land use, no commercial or industrial land use, no State-maintained roads, and only 2.5 percent of its area consists of locallymaintained roads. The stream discharges directly into Stony Brook Reservoir not far from the intake for the aqueduct to Fresh Pond.

The topography of the subbasins ranges from gently rolling hills in the Stony Brook subbasin to fairly steep along the extreme eastern edge of the drainage area. Mean subbasin slopes are range from 17 to 20 percent (vertical change per unit horizontal change), with the exception of the subbasin defined by station 01104455 , which has a mean slope of 37 percent. Surficial geology of the subbasins consists of sand-and-gravel deposits and glacial till or bedrock. There are numerous exposures of bedrock throughout the drainage basin.

\section{Methods of Data Collection and Analysis}

Data collection and analysis involved a large number of techniques and procedures, some of which had to be modified to accomodate problems unique to specific sampling stations. These modifications are presented in detail in the appropriate sections below.

\section{Stage and Discharge Measurements}

Discharge was measured at all stations with current meters using standard USGS procedures (Rantz and others, 1982). Stage was converted to discharge based on measured stage-discharge relations (Rantz and others, 1982). Stage and discharge were determined simultaneously at intervals of about 4 weeks during the 13-month study period. Additional discharge measurements were obtained at high and low flows. Daily mean discharges at three of the continuous-record gaging stations (stations 01104410 , 01104420 , and 01104460 ) were estimated for part or all of October 1997 because the stations were not fully operational for the entire month. This estimation was done using hydrograph comparison methods with nearby continuous streamflow-gaging stations. At station 01104455 , daily mean discharges were estimated from October 1997 through mid-April 1998 using hydrograph comparison methods.

Streamflow measurements at the partial-record stations were correlated with concurrent daily mean discharges from at least six nearby continuous-record streamflow-gaging stations. A scatter plot of logtransformed instantaneous streamflow at the partialrecord station and same-day log transformed daily mean discharges at each of the six nearby continuous streamflow-gaging stations was made to determine the nature and quality of the relation among the 
stations. When the scatter plots indicated a log-linear relation, the maintenance of variance extension, type 1 (MOVE.1) technique (Hirsch, 1982), was used to provide an equation that relates streamflow at the partialrecord station to that at the continuous streamflowgaging station. The daily mean discharges for the 1998 water year at the continuous streamflow-gaging station were substituted into the equation to obtain the corresponding daily mean discharges for the partial-record stations. Retransformation of the daily mean discharge data (that is, taking the antilog) can introduce a bias. In this study, the Duan's smearing method (Duan, 1983) was used to calculate the bias-correction factor for each equation between a partial-record station and continuous-streamflow-gaging station (U.S. Geological Survey, 1992). Each continuous streamflow-gaging station estimate of daily mean discharge at the partialrecord stations was then weighted based on the calculated mean squared error from each stations equation to obtain a weighted estimate of daily mean discharge at the partial-record station.

Estimates of daily mean discharge at the partialrecord station on Stony Brook at Kendal Green, Mass. (station 01104390), were based on hydrographs for continuous USGS streamflow-gaging stations on the Assabet River at Maynard, Mass. (station 01097000, about $16 \mathrm{~km}$ west of the study area); on Nashoba Brook near Acton, Mass. (station 01097300, about $16 \mathrm{~km}$ northwest of the study area); and on the Charles River at Dover, Mass. (station 01103500 , about $10 \mathrm{~km}$ south of the study area). Estimates of daily mean discharge at the partial-record station on the unnamed tributary to Stony Brook Reservoir (station 01104475) were based on the upper Hobbs Brook continuous streamflowgaging stations 01104405 and 01104420 . Attempts to estimate daily mean discharges at the remaining partial-record station (station 01104433 ) resulted in unit runoff values (discharge per unit area) that were inconsistent with those obtained for the other 10 stations. Therefore, constituent loads and yields could not be calculated for station 01104433 .

\section{Chemical Sampling and Analysis}

All 11 stream-monitoring stations were sampled every 4 to 6 weeks from October 1997 through September 1998. Water samples for chemical analysis were collected at stream and reservoir sampling stations using clean-sampling protocols (Wilde and others, 1999) for all aspects of sample collection, preservation, and transport. Samples were collected by combining volumes of water proportional to the amount of discharge at 10-12 equally spaced points along a stream cross section (Edwards and Glysson, 1999). Filterable fractions of metals, nutrients, and common ions were obtained by filtration through acid-cleaned, in-line capsule filtration units with 0.45-micrometer pore-size filters. Sample preparation, analysis, and quality assurance were as described previously for the reservoir investigations.

\section{Event Sampling}

Sampling for nutrients, major ions, dissolved manganese and dissolved iron was conducted during eight precipitation, snowmelt, or salt-application events. Sampling was conducted during rainstorms in November 1997, February 1998, March 1998, and June 1998, and during snowstorms in December 1997 and January 1998. Stations usually were sampled three to four times during the course of an event. However, usually only 4 or 5 of the 11 stations could be sampled in this way during a single rain or snow storm.

\section{Loading Calculations}

Annual mean loads for nitrate nitrogen, total nitrogen, total phosphorus, dissolved iron, dissolved manganese, DOC, and THMFP were computed for water year 1998 at 10 of the stations (excluding station 01104433 ) using the USGS program ESTIMATOR.93. This program calculates annual and monthly mean constituent loads based on the relation between the logarithm of the sampled constituent concentration and the concurrent logarithm of streamflow, and applies the relation to the daily mean discharge record for the 
period of interest (Cohn and others, 1989). Constituent concentration data and discharge records were evaluated for each station to determine the validity of the model used. For most stations and constituents, the model:

$$
\ln [C]=B_{0}+B_{1} \ln [Q]+e
$$

was used, where $\ln []$ denotes the natural logarithm function, $C=$ constituent concentration, $Q=$ discharge, $B_{0}$ is a constant, $B_{1}$ is a coefficient estimated from the data, and $e$ is an independent random error.

Subbasin loads for dissolved sodium, dissolved chloride, and fecal coliform bacteria could not be computed using ESTIMATOR.93 because transport of these constituents in the streams within the basin was not always a simple function of stream discharge. Increased concentrations of dissolved sodium and chloride usually occurred during road-salt applications, when small amounts of highly saline slush entered the streams with little or no change in discharge.

Continuous concentrations of sodium and chloride were calculated for seven of the eight continuous streamflow-gaging stations (all except station 01104455 ) based on relations between measured concentrations of sodium and chloride and concurrent continuous specific conductance records. Coefficients of determination $\left(R^{2}\right)$ for these relations ranged from 0.962 to 0.999 for sodium and from 0.957 to 1.000 for chloride. The MOVE.1 technique (Hirsch, 1982) was used to develop equations to represent these relations, and the Duan's (1983) smearing method was used to determine the bias correction factor (U.S. Geological Survey, 1992). The continuous specific conductance record (15- or 20-minute values) for the 1998 water year were substituted into the equation to obtain the corresponding continuous sodium and chloride concentration records. The estimated continuous sodium and chloride concentration records then were multiplied by the corresponding continuous streamflow records and a unit conversion factor to calculate a continuous sodium and chloride discharge record (15- or 20-minute values) at the seven continuous streamflow-gaging stations for the 1998 water year. The continuous sodium and chloride discharges then were multiplied by the time interval between values (15- or 20-minutes) and summed for the day to determine daily sodium and chloride load.
To calculate sodium and chloride loads at the partial-record station on Stony Brook at Kendal Green, Mass. (station 01104390), an estimate of daily mean specific conductance first was developed based on the relation between instantaneous specific conductance (collected concurrently with sodium and chloride concentration data) and concurrent instantaneous streamflow. Specific conductance was negatively related to streamflow with $R^{2}$ equal to 0.916 . The MOVE. 1 technique was used to develop an equation to represent the relation between specific conductance and flow, and the Duan's smearing method was used to determine the bias correction factor. The estimated daily mean discharge record for the 1998 water year was substituted into the equation to obtain the corresponding daily mean specific conductance. Estimates of daily mean sodium and chloride concentration then were developed based on the relation between the instantaneous measured sodium and chloride concentrations and concurrent instantaneous specific conductance values. The $R^{2}$ for this positive relation between instantaneous sodium concentration and concurrent instantaneous specific conductance was 0.912 , and $R^{2}$ for the positive relation between instantaneous chloride concentration and concurrent instantaneous specific conductance was 0.944 . The MOVE. 1 technique was used to develop equations to represent the relations between specific conductance and sodium and chloride, respectively, and the Duan's smearing method was used to determine the bias correction factor. The estimated daily mean specific conductance record for the 1998 water year was substituted into the equation to obtain the corresponding daily mean sodium and chloride concentrations. Next, the daily mean sodium and chloride concentrations were multiplied by the daily mean discharge and a unit conversion factor to determine the daily mean sodium and chloride discharge, and this value then was multiplied by the number of seconds in a day to determine the daily sodium and chloride loads.

Median instantaneous sodium and chloride loads for stations 01104455 and 01104475 were determined by multiplying each measured sodium and chloride concentration by the corresponding instantaneous discharge and then finding the median value for the water year. The same approach was used to compute median instantaneous fecal coliform bacteria loads for all stations except station 01104433. 


\section{Constituent Concentrations, Estimated Loads, and Subbasin Yields}

Concentrations of fecal coliform bacteria, dissolved sodium, dissolved chloride, nitrate nitrogen, ammonia nitrogen, total nitrogen, total phosphorus, orthophosphate phosphorus, dissolved iron, dissolved manganese, DOC, and THMFP in samples collected from the 11 subbasin monitoring stations in the Cambridge drinking-water source area are presented as truncated box plots in figures $7 A-7 L$ (see p. 75). Box plots provide information on both the central value (median concentration) of each constituent and the variability and skewness of the data. In truncated box plots, the highest and lowest 10 percent of the data are not represented, and whiskers are drawn to the 10th and 90th percentiles of the data. Truncation allows the majority of the data to be plotted without compressing the scale of the box to show extreme outliers; maximum measured concentrations will be reported in the discussion that follows.

The Commonwealth of Massachusetts sets minimum quality standards for surface water based on the intended uses of the water. Inland waters that are sources of drinking water are designated "Class A." Applicable standards for Class A streams and reservoirs in the Cambridge drinking-water source area are presented in table 6 , together with the ranges and median values for selected water-quality characteristics recorded in this study.

Estimated annual mean daily loads (in kilograms per day) and subbasin yields (in kilograms per square kilometer per day) for dissolved sodium, dissolved chloride, nitrate nitrogen, total nitrogen, total phosphorus, dissolved iron, dissolved manganese, DOC, and

Table 6. Ranges and median values for selected physical and chemical characteristics of water in the drinking-water source area for Cambridge, Massachusetts, October 1997-November 1998, in relation to Massachusetts source-water and Federal drinking-water standards

[DWEL, drinking water equivalent level; MCL, maximum contaminant level; SMCL, secondary maximum contaminant level; TTHM, total trihalomethanes formed during disinfection with chlorine; USEPA, U.S. Environmental Protection Agency. Median values for this study are given in parentheses following the ranges. $\mathrm{mg} / \mathrm{L}$, milligrams per liter; $\mu \mathrm{g} / \mathrm{L}$, micrograms per liter; $\mathrm{CFU} / 100 \mathrm{~mL}$, colony forming units per 100 milliliters; ${ }^{\circ} \mathrm{C}$, degrees Celsius; $<$, actual value is less than reported value; $\geq$, actual value is greater than or equal to reported value; --, no standard has been established or not measured]

\begin{tabular}{|c|c|c|c|c|c|c|c|c|}
\hline \multirow{2}{*}{ Constituent } & \multirow{2}{*}{$\begin{array}{l}\text { Massachusetts } \\
\text { Class "A" surface } \\
\text { water standards } \\
\text { (raw water) }\end{array}$} & \multicolumn{4}{|c|}{$\begin{array}{l}\text { Cambridge drinking-water } \\
\text { source area }\end{array}$} & \multicolumn{3}{|c|}{ USEPA } \\
\hline & & \multicolumn{2}{|c|}{ Tributary streams } & \multicolumn{2}{|c|}{ Reservoir } & $\begin{array}{l}\text { Drinking- } \\
\text { water }\end{array}$ & $\begin{array}{l}\text { Drinking- } \\
\text { water }\end{array}$ & $\begin{array}{l}\text { DWEL } \\
\text { (guide- }\end{array}$ \\
\hline pH & $6.5-8.3$ & $4.1-8.7$ & (6.7) & $5.8-8.1$ & $(6.9)$ & -- & -- & -- \\
\hline 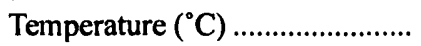 & $a_{<}<28.3$ & $0-26.1$ & $(8.8)$ & $0.2-27.7$ & $(13.4)$ & -- & $\cdots$ & -- \\
\hline $\begin{array}{l}\text { Fecal coliform bacteria } \\
\quad(\mathrm{CFU} / 100 \mathrm{~mL})\end{array}$ & $\mathrm{b}_{20}$ & $0-1,700$ & ${ }^{c}(48)$ & -- & & -- & -- & -- \\
\hline Sodium $(\mathrm{mg} / \mathrm{L})$ & -- & $12-11,200$ & $(66)$ & $15-113$ & $(59.5)$ & -- & -- & 20 \\
\hline Chloride $(\mathrm{mg} / \mathrm{L}) \ldots \ldots \ldots \ldots \ldots \ldots$ & -- & $20-21,000$ & $(120)$ & $35-200$ & $(110)$ & -- & 250 & -- \\
\hline Nitrate $(\mathrm{mg} / \mathrm{L}$ as $\mathrm{N})$..................... & -- & $0.05-2.13$ & $(0.478)$ & $0.05-0.79$ & $(0.20)$ & 10 & -- & - \\
\hline Nitrite $(\mathrm{mg} / \mathrm{L}$ as $\mathrm{N})$......................... & -- & $0.01-0.057$ & $(0.014)$ & $0.01-0.055$ & $(0.014)$ & 1 & -- & -. \\
\hline Sulfate $\left(\mathrm{mg} / \mathrm{L}\right.$ as $\left.\mathrm{SO}_{4}\right) \ldots \ldots \ldots \ldots \ldots$ & -- & $4.5-190$ & $(16)$ & $0.15-32$ & (13) & -- & 250 & - \\
\hline Iron $(\mu \mathrm{g} / \mathrm{L})$ & -- & $3.6-1,200$ & $(165)$ & $3-17,300$ & $(115)$ & -- & 300 & - \\
\hline Manganese $(\mu \mathrm{g} / \mathrm{L})$ & -. & $1.7-1,420$ & $(124)$ & $1.5-12,700$ & $(103)$ & -- & 50 & -- \\
\hline Dissolved oxygen $(\mathrm{mg} / \mathrm{L})$........... & $d \geq 6.0$ & $0.9-15$ & $(10.1)$ & $0-14.7$ & $(8.1)$ & -- & -- & -- \\
\hline TTHM $(\mu \mathrm{g} / \mathrm{L}) \ldots \ldots \ldots \ldots \ldots \ldots \ldots \ldots$ & -- & $53-370$ & $(200)$ & $55-366$ & $(281)$ & 80 & -- & - \\
\hline
\end{tabular}

${ }^{a}$ Criterion for warm water fisheries.

${ }^{b}$ Arithmetic mean of a set of representative samples.

cArithmetic mean of all determinations.

${ }^{\mathrm{d}}$ Except where background conditions are lower. 
THMFP for ten of the eleven subbasin monitoring stations (excluding station 01104433) are presented in table 7 . Also presented in table 7 are median instantaneous loads and subbasin yields for fecal coliform bacteria. Error estimates based on the agreement between the measured and calculated constituent concentration data are provided for loads and yields determined with ESTIMATOR.93. Standard errors for discharge records used to calculate loads in this study ranged from 10 to 18 percent for continuous-record stations and from 21 to 56 percent for partial-record stations, with an overall median of 13 percent. Those for specific conductance ranged from 5.1 to 8.8 percent with a median of 6 percent.

\section{Fecal Coliform Bacteria}

Most concentrations of fecal coliform bacteria in water samples collected at the 11 monitoring stations were less than $200 \mathrm{CFU} / 100 \mathrm{~mL}$ (colony forming units per 100 milliliters of sample water) (fig. 7A). Event sampling (precipitation and road-salt application), however, produced much higher maximum concentrations (up to $1,700 \mathrm{CFU} / 100 \mathrm{~mL}$ at station 01104420 ), especially when the event was preceded by at least 3 days of dry weather. The water samples with the lowest maximum concentrations were collected at stations $01104430(100 \mathrm{CFU} / 100 \mathrm{~mL})$ and 01104440 $(140 \mathrm{CFU} / 100 \mathrm{~mL})$, both of which receive most of their flow from Hobbs Brook Reservoir, and 01104475 (50 CFU/100 mL), which drains a small, predominantly low-density residential subbasin. Median concentrations determined during the study period ranged from $20 \mathrm{CFU} / 100 \mathrm{~mL}$ for samples collected at stations 01104475 and 01104390 to $200 \mathrm{CFU} / 100 \mathrm{~mL}$ for samples collected at station 01104410 . The State standard for fecal coliform bacteria in streams in the Cambridge drinking-water source area is $20 \mathrm{CFU} / 100$ $\mathrm{mL}$, based on the arithmetic mean of a representative set of samples (table 6). This standard was met only during the winter months at most stations and was not met at all during the study period at station 01104455 .

Median instantaneous fecal coliform bacteria loads ranged from 3,200 CFU/s (colony forming units per second) at station 01104475 to $800,000 \mathrm{CFU} / \mathrm{s}$ at station 01104390 (table 7). The median instantaneous load at station 01104390 , which integrates most of the Stony Brook subbasin, was only slightly larger than that at station 01104440 at the mouth of Hobbs Brook, which drains an area similar in size but more intensely developed and with greater road density than the Stony Brook subbasin.

Subbasin yields (load per unit area) provide a more direct comparison among subbasins that differ in size. Median instantaneous yields of fecal coliform bacteria (CFU $/ \mathrm{km}^{2} / \mathrm{s}$ [colony forming units per square kilometer per second]) varied widely among subbasins, but most were in the range of 4,000 to 23,000 CFU $/ \mathrm{km}^{2} / \mathrm{s}$ (table 7). Exceptions were station 01104455 , which produced an estimated yield of $29,000 \mathrm{CFU} / \mathrm{km}^{2} / \mathrm{s}$ and station 01104475 , where the yield was $1,500 \mathrm{CFU} / \mathrm{km}^{2} / \mathrm{s}$.

\section{Sodium and Chloride}

Concentrations of dissolved sodium and chloride varied in similar ways at each of the monitoring stations (figs. $7 B$ and $7 C$ ). Highest maximum concentrations $(5,220 \mathrm{mg} / \mathrm{L}$ for sodium and $9,050 \mathrm{mg} / \mathrm{L}$ for chloride) were measured at station 01104415 during a March 1998, road-salt application event. Highest median concentrations $(258 \mathrm{mg} / \mathrm{L}$ for sodium and $463 \mathrm{mg} / \mathrm{L}$ for chloride) also were obtained at station 01104415 . Concentrations measured at stations 01104415,01104420 , and 01104455 had the largest ranges.

Whereas no State or Federal standards are set for sodium and chloride in surface waters, the U.S. Environmental Protection Agency (USEPA) has established a secondary maximum contaminant level (SMCL) for chloride of $250 \mathrm{mg} / \mathrm{L}$ and a drinking-water equivalent level guideline for sodium of $20 \mathrm{mg} / \mathrm{L}$ (table 6). Because these constituents are difficult to remove during conventional drinking-water treatment, comparison of finished water standards with measured concentrations in the streams and reservoirs is relevant (table 6). All 11 sampling stations had dissolved sodium concentrations in excess of the guideline at least once during the study and nine of the stations had dissolved sodium concentrations in excess of the guideline at least 50 percent of the time (that is, median dissolved sodium concentrations were greater than $20 \mathrm{mg} / \mathrm{L}$ ). Six of the stations had dissolved chloride concentrations in excess of the SMCL at least once during the study and one station had dissolved chloride concentrations in excess of the SMCL at least 50 percent of the time. 


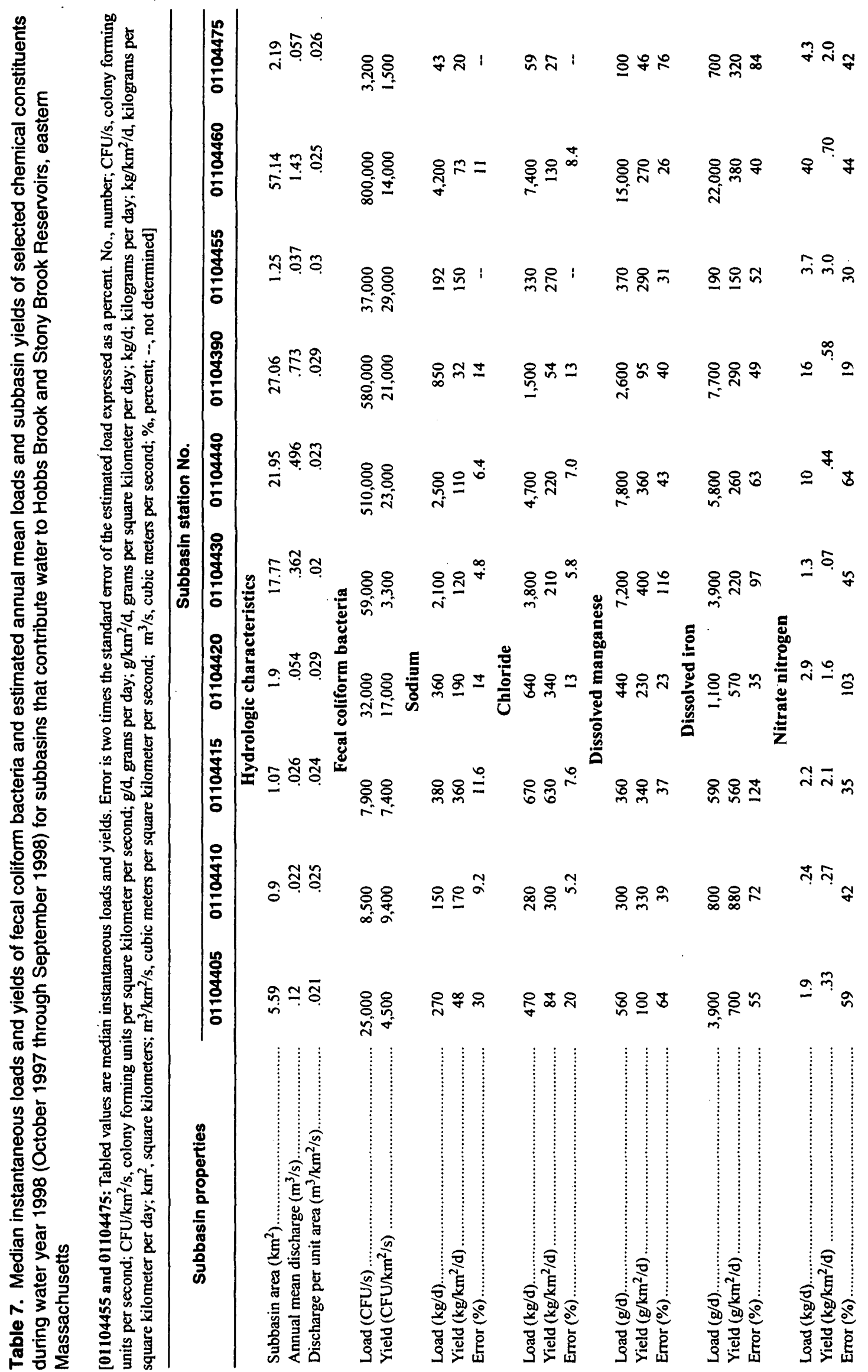




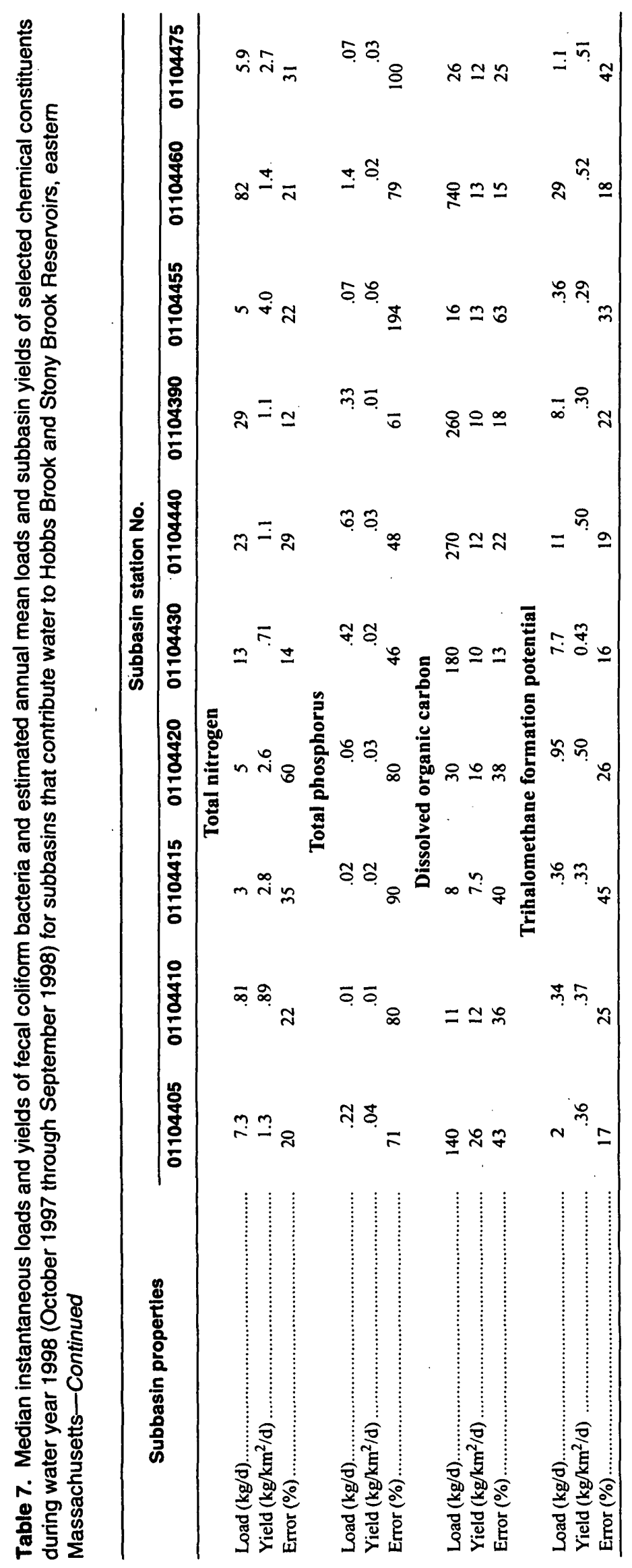


Estimated loads of dissolved sodium and chloride from the Hobbs Brook subbasin were much larger than those from the Stony Brook subbasin (table 7), despite the fact that the two subbasins occupy similar areas. The estimated loads at the mouth of Hobbs Brook above the Stony Brook confluence (station 01104440) were $2,500 \mathrm{~kg} / \mathrm{d}$ for dissolved sodium and $4,700 \mathrm{~kg} / \mathrm{d}$ for dissolved chloride. About 84 percent of the dissolved sodium load and 81 percent of the dissolved chloride load were accounted for by the discharge from Hobbs Brook Reservoir. In contrast, the estimated loads at the Stony Brook station just upstream from the Hobbs Brook confluence station 01104390 ) were $850 \mathrm{~kg} / \mathrm{d}$ for dissolved sodium and $1,500 \mathrm{~kg} / \mathrm{d}$ for dissolved chloride. The sum of the sodium loads from the Hobbs Brook subbasin, the Stony Brook subbasin upstream from Kendal Green, Mass., and the unnamed tributary (station 01104455 ) that enters Stony Brook upstream from station 01104460 , indicates that another $658 \mathrm{~kg} / \mathrm{d}$ entered Stony Brook in the area between these stations and station 01104460 , and subsequently was discharged to Stony Brook Reservoir.

Estimated subbasin yields for dissolved sodium and chloride were largest at stations 01104410 , 01104415,01104420 , and 01104455 (table 7), all of which are heavily affected by State-maintained roads (table 5). Subbasins upstream from stations 01104415 and 01104455 have the highest areal percentages of State-maintained roads and station 01104420 has the highest areal percentage of locally maintained roads of any station in the monitoring network (table 5). Estimated sodium yields at these stations ranged from $150 \mathrm{~kg} / \mathrm{km}^{2} / \mathrm{d}$ at station 01104455 to $360 \mathrm{~kg} / \mathrm{km}^{2} / \mathrm{d}$ at station 01104415 . Subbasins from the remaining upper Hobbs Brook station (station 01104405), together with those for the Stony Brook integrator station at Kendal Green (station 01104390) and the unnamed tributary that discharges directly into Stony Brook Reservoir (station 01104475 ), produced estimated dissolved sodium yields ranging from 20 to $48 \mathrm{~kg} / \mathrm{km}^{2} / \mathrm{d}$. These subbasins contained little or no State-maintained road area (table 5).

\section{Nitrogen}

Median concentrations of nitrate nitrogen varied among the monitoring stations, as did the concentration ranges (fig. 7D). Most samples from the station just downstream from Hobbs Brook Reservoir (station
01104430) had nitrate nitrogen concentrations that were at or below the minimum reporting level (MRL) of $0.05 \mathrm{mg} / \mathrm{L}$. These results produced a median concentration for that station equal to the MRL. Median concentrations determined for most of the other stations were $0.5 \mathrm{mg} / \mathrm{L}$ or lower. Median concentrations at two of the stations, stations 01104415 and 01104455 , were higher at 1.22 and $1.52 \mathrm{mg} / \mathrm{L}$, respectively. These stations also had the widest ranges of nitrate nitrogen concentrations, with maximum concentrations of 1.72 and $2.13 \mathrm{mg} / \mathrm{L}$ at stations 01104415 and 01104455 , respectively. Although no State surface-water standard for nitrate nitrogen is available, the USEPA's MCL (maximum contaminant level) for finished drinking water is $10 \mathrm{mg} / \mathrm{L}$ (table 6 ).

Highest median concentrations of ammonia nitrogen were determined for stations 01104415 $(0.12 \mathrm{mg} / \mathrm{L}), 01104420(0.12 \mathrm{mg} / \mathrm{L})$, and 01104433 $(0.16 \mathrm{mg} / \mathrm{L})$ (fig. $7 E$ ). Subbasins for these stations also had high areal percentages of commercial and industrial land use (table 5). Highest maximum concentrations were in samples collected at stations 01104420 $(1.69 \mathrm{mg} / \mathrm{L})$ and $01104455(1.23 \mathrm{mg} / \mathrm{L})$ during runoff and road-salt application events. Both these stations receive most of their flow from culverts extending underneath State Route 128.

The pattern of total nitrogen concentrations in water samples collected at the 11 subbasin-monitoring stations reflected the high variability of the nitrate nitrogen concentrations in the same samples (fig. $7 F$ ), as most nitrogen in the samples was nitrate. As with the nitrate nitrogen concentrations, median and maximum concentrations of total nitrogen were highest at stations 01104415 and 01104455.

The Hobbs Brook subbasin (station 01 104440) and the Stony Brook subbasin upstream from Kendal Green (station 01104390) produced similar estimated loads for both nitrate nitrogen and total nitrogen (table 7). Subbasin yields of the two nitrogen species also were similar, and were comparable in magnitude to those determined for the combined drainage basin upstream from station 01104460 . The estimated subbasin yield for nitrate nitrogen at this station was $0.70 \mathrm{~kg} / \mathrm{km}^{2} / \mathrm{d}$ and that for total nitrogen was $1.4 \mathrm{~kg} / \mathrm{km}^{2} / \mathrm{d}$. However, appreciably larger yields ranging from 1.6 to $3.0 \mathrm{~kg} / \mathrm{km}^{2} / \mathrm{d}$ for nitrate nitrogen and from 2.6 to $4.0 \mathrm{~kg} / \mathrm{km}^{2} / \mathrm{d}$ for total nitrogen were obtained at stations $01104415,01104420,01104455$, and 01104475 . The higher yields at station 01104475 
may be indicative of fertilizer applications or septicsystem leachate, as land use in this subbasin is primarily low-density residential (table 5).

\section{Phosphorus}

Median total phosphorus concentrations at most stations were equal to the MRL $(0.01 \mathrm{mg} / \mathrm{L})$ (fig. 7G). Highest median total phosphate concentrations were about twice the MRL. Maximum concentrations ranged from $0.024 \mathrm{mg} / \mathrm{L}$ in a sample collected at the Stony Brook integrator site near Kendal Green, Mass. (station 01104390 ) to $0.133 \mathrm{mg} / \mathrm{L}$ in a sample collected at station 01104420 in the upper Hobbs Brook subbasin. There was little station-to-station variability in median orthophosphate phosphorus concentrations (fig. $7 \mathrm{H}$ ), although the highest median concentration $(0.016 \mathrm{mg} / \mathrm{L}$, at station 01104410$)$ was four times greater than the lowest median concentration $(0.004 \mathrm{mg} / \mathrm{L}$, at station 01104460$)$. Maximum concentrations also were similar, ranging only from $0.016 \mathrm{mg} / \mathrm{L}$ at stations 01104475 and 01104430 to $0.026 \mathrm{mg} / \mathrm{L}$ at station 01104415 . Orthophosphate phosphorus is the form of phosphorus that is most readily available to stimulate growth of phytoplankton algae (Wetzel, 1993).

The estimated total phosphorus load at the mouth of Hobbs Brook (station $01104440,0.63 \mathrm{~kg} / \mathrm{km}^{2} / \mathrm{d}$ ) was nearly twice that at the Stony Brook integrator station (station $01104390,0.33 \mathrm{~kg} / \mathrm{km}^{2} / \mathrm{d}$ ). The largest yield was from station 01104455 , but a high standard error was associated with that estimate. In general, phosphorus yields were small (less than $0.6 \mathrm{~kg} / \mathrm{km}^{2} / \mathrm{d}$ ).

\section{Iron and Manganese}

Iron and manganese enter streams primarily from natural geologic sources. Both metals become soluble under anoxic conditions and so water discharging from wetland soils frequently is enriched with them. Under aerobic conditions, iron rapidly is oxidized and precipitates as a ferric oxyhydroxide. Manganese may remain in solution even under aerobic conditions and both metals may form complexes with dissolved organic matter (Hem, 1985). Both metals are undesirable in drinking-water supplies because they tend to deposit as oxides on plumbing fixtures. Manganese oxides are common on rocks in the Hobbs Brook Reservoir tailrace and throughout the Stony Brook Reservoir Basin.
In the Cambridge Reservoir system, median concentrations of dissolved iron and manganese varied greatly from station to station, depending on sources and proximity of the station to anoxic inflows. Samples from stations $01104410,01104415,01104420$, and 01104433 produced the highest median concentrations for both metals ( 200 to $280 \mu \mathrm{g} / \mathrm{L}$ for iron and 145 to $286 \mu \mathrm{g} / \mathrm{L}$ for manganese) (figs. $7 I$ and 7 ). All four statiions receive ground water rich in iron and manganese during base flow. Samples from tributary stations 01104455 and 01104475 and Hobbs Brook station 01104430 produced the lowest median concentrations (35-50 $\mu \mathrm{g} / \mathrm{L}$ for iron and 5.3-54 $\mu \mathrm{g} / \mathrm{L}$ for manganese). Station 01104430 receives discharge from Hobbs Brook Reservoir and, although there was considerable dissolved iron and manganese in the discharge during summer stratification, this did not result in elevated median concentrations.

Maximum concentrations of iron ranged from $130 \mu \mathrm{g} / \mathrm{L}$ in samples from station 01104475 to $1,200 \mu \mathrm{g} / \mathrm{L}$ in samples from station 01104405 . Maximum concentrations of manganese ranged from 22 in samples from station 01104475 to $1,420 \mu \mathrm{g} / \mathrm{L}$ in samples from station 01104433 . The USEPA has set secondary MCLs for iron and manganese in finished drinking water at $300 \mu \mathrm{g} / \mathrm{L}$ and $50 \mu \mathrm{g} / \mathrm{L}$, respectively (table 6).

The Hobbs Brook and Stony Brook subbasins (defined by stations 01104440 and 01104390 , respectively) produced similar estimated annual mean loads for iron $(5,800$ and $7,700 \mathrm{~g} / \mathrm{d}$, respectively) (table 7). However, the estimated annual mean manganese load from the Hobbs Brook subbasin was greater $(7,800 \mathrm{~g} / \mathrm{d} \pm 43 \%)$ than that from the Stony Brook subbasin (2,600 g/d $\pm 40 \%)$. Estimated annual mean yields for iron were greatest at stations representing the upper Hobbs Brook subbasins, stations $01104405\left(700 \mathrm{~g} / \mathrm{km}^{2} /\right.$ day $)$ and 01104410 $\left(880 \mathrm{~g} / \mathrm{km}^{2} /\right.$ day $)$. Those for manganese were greatest at the two stations downstream from Hobbs Brook Reservoir, stations 01104430 (400 g/ $\mathrm{km}^{2} /$ day) and 01104440 (360 g/ $\mathrm{km}^{2} /$ day). These higher dissolved manganese loads likely were due to releases from Hobbs Brook Reservoir bed sediments during periods when the reservoir was thermally stratified and the hypolimnion was anoxic. 


\section{Dissolved Organic Carbon and Trihalomethane Formation Potential}

The median concentration of DOC was highest $(8.5 \mathrm{mg} / \mathrm{L})$ in samples from the upper Hobbs Brook station (station 01104405), which drains a large red maple swamp, and lowest $(2.7 \mathrm{mg} / \mathrm{L})$ in samples from station 01104455 , which drains a small, moderately sloped subbasin with large amounts of paved area and almost no wetland area (fig. $7 K$ ). The highest maximum concentration $(19 \mathrm{mg} / \mathrm{L})$ also was measured at station 01104405.

Median concentrations of THMFP ranged from $0.085 \mathrm{mg} / \mathrm{L}$ at station 01104455 to $0.273 \mathrm{mg} / \mathrm{L}$ at the mouth of Hobbs Brook (station 01 104440). Maximum concentrations were more uniform, ranging from $0.204 \mathrm{mg} / \mathrm{L}$ at station 01104455 to $0.370 \mathrm{mg} / \mathrm{L}$ at station 01104390 . These values are similar to the concentration range $(0.144$ to $0.421 \mathrm{mg} / \mathrm{L})$ reported by Krasner and others (1994) for the San Joaquin and Sacramento Rivers in central California. The USEPA drinking-water standard for THMFP is $0.080 \mathrm{mg} / \mathrm{L}$ (table 6).

Estimated annual mean yields of DOC and THMFP were remarkably uniform, suggesting that no subbasin was exporting a disproportionate amount of either constituent on an annual basis. One exception was station 01104405, where the estimated DOC yield was two to three times greater than those of the other stations.

\section{Constituent Yields in Relation to Subbasin Characteristics}

To examine relations between subbasin characteristics and constituent yields in more detail, a correlation analysis was performed relating percent areal coverage of 28 land-use, land-cover, topographic, and geologic features to the estimated annual mean yields of selected water-quality constituents in 10 of the Cambridge subbasins. Station 01104433 was excluded from the analysis because yields were not estimated for that station. Product-moment correlation coefficients $(r)$ showing the relative degree of association between each basin characteristic and each constituent yield are presented in table 8 . The product-moment correlation coefficient can range in value from -1.00 to +1.00 . A correlation coefficient of $r=+1.00$ signifies a perfect positive linear relation; a correlation coefficient of $r=-1.00$ indicates a perfect negative or inverse linear relation between the two variables. A correlation coefficient of $r=0$ indicates no relation between the respective values of the two variables. The square of the correlation coefficient $\left(r^{2}\right)$ indicates the proportion of variance in one of the variables accounted for by the variance in the other variable (Kachigan, 1986). No assumptions regarding cause and effect are made in correlation analysis. Rather, the analysis determines the extent to which the observed variation in one variable is coincident with the observed variation in another variable. However, the analysis can be useful in selecting relations for more detailed investigation. In the following discussion, a significant correlation between two variables is defined as one in which at least 50 percent of the variance in one variable is accounted for by the variance in the other variable; that is, the correlation coefficient $(r)$ is less than or equal to -0.710 , or is greater than or equal to +0.710 .

By the criteria used, there were few significant correlations between estimated 1998 subbasin constituent yields and the subbasin characteristics selected for analysis. There were no significant correlations between subbasin median instantaneous fecal coliform bacteria yields and any of the 28 subbasin characteristics tested (table 8). Also, no significant correlations between THMFP yields and any subbasin characteristics were present, although there was a significant positive correlation $(r=0.729)$ was determined between the estimated subbasin DOC yield and the percent coverage of forested wetlands in the subbasins.

The estimated subbasin yield of nitrate nitrogen was negatively correlated with pasture $(r=-0.753)$ and forested wetland $(r=-0.759)$. Total nitrogen yield was negatively correlated with pasture $(r=-0.730)$. Total phosphorus yield was negatively correlated with nonforested wetland $(r=-0.742)$ and positively correlated $(r=0.780)$ with the mean slope of the subbasins. Manganese yield was negatively correlated $(r=-0.774)$ with the percentage of low-density residential land use.

The apparent positive correlation $(r=0.774)$ between total phosphorus yield and industrial land use is due to the relatively large amount of industrial land use ( 20 percent) and the large total phosphorus yield $\left(0.057 \mathrm{~kg} / \mathrm{km}^{2} / \mathrm{d}\right)$ in the subbasin defined by station 01104455 . If this subbasin is omitted from the analysis, then no correlation is present. Similarly, the correlation between subbasin yield of dissolved iron and percent areal coverage of floodplain alluvium is due entirely to 
Table 8. Product moment correlation coefficients $(\lambda)$ relating percent areal coverage of subbasin characteristics to estimated annual mean yields (mass per unit area) of ten potential contaminants in subbasins of the drinking-water source area for Cambridge, Massachusetts, October 1997-September 1998

[Fecal coliform bacteria expressed as median instantaneous yield. DOC, dissolved organic carbon; THMFP, trihalomethane formation potential]

\begin{tabular}{|c|c|c|c|c|c|c|c|c|c|c|}
\hline Subbasin characteristic & $\begin{array}{c}\text { Fecal } \\
\text { coliform } \\
\text { bacteria }\end{array}$ & Sodlum & Chloride & $\begin{array}{c}\text { Nitrate } \\
\text { nitrogen }\end{array}$ & $\begin{array}{c}\text { Total } \\
\text { nitrogen }\end{array}$ & $\begin{array}{c}\text { Total } \\
\text { phos- } \\
\text { phorus }\end{array}$ & $\begin{array}{l}\text { Dis- } \\
\text { solved } \\
\text { iron }\end{array}$ & $\begin{array}{l}\text { Dis- } \\
\text { solved } \\
\text { manga- } \\
\text { nese }\end{array}$ & DOC & THMFP \\
\hline 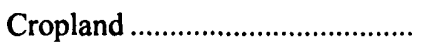 & -0.042 & -0.289 & -0.272 & -0.604 & -0.633 & -0.578 & 0.232 & -0.222 & 0.079 & -0.388 \\
\hline 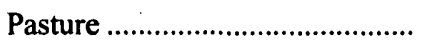 & -.177 & -.362 & -.331 & -.753 & -.730 & -.386 & $.588^{\circ}$ & -.083 & .410 & -.254 \\
\hline 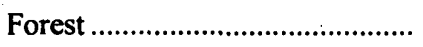 & -.074 & -.510 & -.490 & -.679 & -.612 & .025 & .307 & -.078 & .669 & -.229 \\
\hline Forested wetland ............................. & .041 & -.481 & -.457 & -.759 & -.673 & -.181 & .444 & -.271 & .729 & .093 \\
\hline Non-forested wetland ................... & .147 & -.073 & -.043 & -.544 & -.581 & -.742 & .539 & .067 & -.181 & -.145 \\
\hline 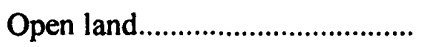 & -.371 & .055 & .076 & -.122 & -.188 & -.462 & .486 & .001 & -.300 & .062 \\
\hline 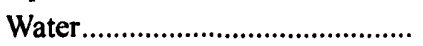 & -.011 & -.236 & -.205 & -.553 & -.582 & -.208 & -.520 & .498 & -.278 & .374 \\
\hline Participatory recreation................ & -.516 & -.343 & -.358 & .311 & .260 & .103 & -.176 & -.573 & -.097 & .391 \\
\hline Spectator recreation ........................ & -.169 & .159 & .174 & -.327 & -.303 & -.094 & .141 & .106 & .284 & -.108 \\
\hline Water-based recreation ................ & .269 & -.423 & -.427 & -.246 & -.300 & -.429 & -.237 & -.337 & -.211 & -.149 \\
\hline Urban open & -.272 & .326 & .351 & -.155 & -.205 & -.557 & .668 & .158 & -.281 & .050 \\
\hline State-maintained roads ................. & .144 & .835 & .812 & .657 & .658 & .347 & -.131 & .503 & -.289 & -.410 \\
\hline Locally maintained roads ........... & .528 & .726 & .713 & .512 & .547 & .130 & .090 & .388 & -.246 & .083 \\
\hline All roads & .318 & .882 & .860 & .669 & .685 & .296 & -.055 & .511 & -.303 & -.253 \\
\hline 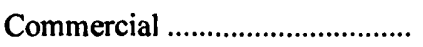 & .420 & .523 & .539 & .029 & .065 & -.057 & .369 & .644 & -.160 & .042 \\
\hline 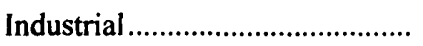 & .217 & .065 & .033 & .621 & .633 & .774 & -.479 & .201 & -.010 & -.373 \\
\hline 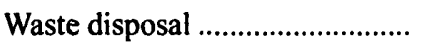 & .269 & -.423 & -.427 & -.246 & -.300 & -.429 & -.237 & -.337 & -.211 & -.149 \\
\hline Mining & .431 & -.224 & -.219 & -.207 & -.204 & -.129 & -.136 & .122 & -.042 & .423 \\
\hline Multi-family residential .............. & .006 & -.425 & -.397 & -.694 & -.705 & -.234 & -.433 & .278 & -.044 & .253 \\
\hline High-density residential............... & .606 & .232 & .216 & .341 & .424 & .384 & -.089 & .146 & .135 & .226 \\
\hline Medium-density residential ........ & .163 & .915 & .906 & .439 & .431 & -.071 & .056 & .422 & -.383 & -.145 \\
\hline Low-density residential ............... & -.317 & -.615 & -.625 & -.027 & -.084 & -.178 & -.279 & -.774 & -.036 & .340 \\
\hline 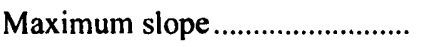 & .400 & -.437 & -.446 & -.062 & -.085 & .143 & -.637 & .099 & -.158 & .019 \\
\hline Mean slope & .084 & -.120 & -.158 & .686 & .689 & .780 & -.497 & -.031 & -.016 & -.197 \\
\hline 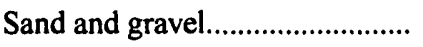 & .130 & .227 & .235 & -.041 & -.069 & -.295 & .251 & -.185 & .028 & -.097 \\
\hline 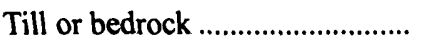 & -.094 & -.253 & -.267 & .119 & .146 & .375 & -.422 & .146 & -.052 & .153 \\
\hline Fine-grained deposits.................... & -.297 & -.291 & -.292 & -.275 & -.181 & .293 & .396 & -.411 & .894 & -.201 \\
\hline Floodplain alluvium...................... & -.116 & .183 & .209 & -.340 & -.346 & -.443 & .786 & .195 & .018 & -.249 \\
\hline
\end{tabular}

the disproportionately large yield $\left(880 \mathrm{~g} / \mathrm{km}^{2} /\right.$ day) and floodplain-alluvium coverage (13 percent) in the subbasin defined by station 01104410 , and the apparent correlation between DOC yield and percent areal coverage of fine-grained deposits is due to the disproportionately large yield of DOC $\left(26 \mathrm{~kg} / \mathrm{km}^{2} / \mathrm{d}\right)$ from the subbasin defined by station 01104405 .

The most consistent relations to emerge from the analysis were those between dissolved sodium and chloride yields and the percent areal coverage of roads in the subbasins. Dissolved sodium yields were positively correlated with percent areal coverage of
State-maintained roads $(r=0.835)$, locally maintained roads $(r=0.726)$, and all roads $(r=0.882)$. Dissolved chloride yield also was positively correlated with sodium yield $(r=0.998)$ and similarly was correlated with State-maintained roads $(r=0.812)$, locally maintained roads $(r=0.713)$, and all roads $(r=0.860)$. A positive correlation between dissolved sodium and chloride yields and percent areal coverage of roads in the subbasins is expected because of the winter application of sodium chloride (road salt) as a road deicing agent. 
Dissolved sodium and chloride yields also were significantly correlated with percent areal coverage of medium-density residential land use in the subbasins. The correlation coefficient for the relation with dissolved sodium was 0.915 and that for dissolved chloride was 0.906 (table 8). Harper and others (1992) found that medium density residential land use was one of three factors that were significant in determining sodium concentrations in drinking-water supply wells. In residential areas, salt is applied to driveways, side walks, and other walk ways. It is unlikely, however, that medium-density residential land was an important source of sodium and chloride in the Cambridge drinking-water source area because there were no significant correlations with other residential land-use categories. Rather, the correlation probably was due to the significant positive correlations between medium-density residential land and State-maintained roads $(r=0.830)$ and between medium-density residential land and all roads $(r=0.857)$.

The ratio of sodium ions to chloride ions in water samples collected during the study gives another indication of the sources of these constituents. The mean ratio of sodium concentration to chloride concentration (both in milligrams per liter) in 266 water samples collected at the 11 monitoring stations was $0.564 \pm 0.008$ (99 percent confidence bounds), and the median ratio was 0.558 . Based on their atomic weights, the ratio of the two ions in sodium chloride $(\mathrm{NaCl})$ salt should be 0.648 . Granato and others (1995), working at a study site in southeastern Massachusetts, found mean sodium to chloride ratios of about 0.63 for direct highway runoff and 0.55 for ground water directly down gradient from the highway. Thus, the water samples collected in the Hobbs Brook Reservoir Basins may be more indicative of ground-water discharge than of stormwater runoff. Many of the samples were collected during baseflow, when streamflow is essentially ground-water discharge. The use of calcium chloride $\left(\mathrm{CaCl}_{2}\right)$ as a partial substitute for sodium chloride on State-maintained roads, an alternative deicing practice in use in the Cambridge drinking-water source area since 1986, also would lower the sodium-to-chloride ratio.

It is likely that State-maintained roads had a greater impact than locally maintained roads on the yields of sodium and chloride in the source area. The estimated annual mean loads of dissolved sodium and chloride for the Hobbs Brook subbasin (station 01104440 ) were about three times greater than those for the Stony Brook subbasin upstream from Kendal Green, Mass., although the drainage areas differ only by about 20 percent $\left(21.9 \mathrm{~km}^{2}\right.$ for the Hobbs Brook subbasin versus $26.0 \mathrm{~km}^{2}$ for the Stony Brook subbasin, table 7). The areal coverage of locally maintained roads is 3.2 percent for the Hobbs Brook subbasin and 2.2 percent for the Stony Brook subbasin (table 5). However, the percent coverage of State-maintained roads is much higher in the Hobbs Brook subbasin (4.3 percent) than it is in the Stony Brook subbasin ( 0.4 percent). The Hobbs Brook subbasin also contains more commercial and industrial land than the Stony Brook subbasin, but these land uses were not correlated with dissolved sodium and chloride yields.

\section{Water and Constituent Mass Balances for Hobbs Brook Reservoir}

Mass balances were determined for water and selected chemical constituents for Hobbs Brook Reservoir for water year 1998. The water balance, which defines the balance between water gains (inflow components) and losses (outflow components) over a given period of time, is a useful tool for general management decisions. The water balance dètermined for Hobbs Brook Reservoir during water year 1998 can be considered a generalized approximation of the overall water availability. Constituent balances can be used to identify critical sources and sinks for potential contaminants entering the reservoir. Because only surfacewater inputs and outputs were measured, and because a large part (39 percent) of the reservoir drainage basin was ungaged, the mass balances are only approximate. Large errors may arise from failure to measure groundwater inflows and outflows and their constituent loads (Winter, 1981).

Monthly water balances were determined for water year 1998 based on the equation

$$
\Delta S=S W_{\text {in }}+G \dot{W}_{\text {in }}+P-S W_{\text {out }}-G W_{\text {out }}-E \pm R,
$$

where $\Delta S$ is the change in storage (change in total reservoir volume); $S W_{\text {in }}$ is the sum of all tributary inflows; $G W_{\text {in }}$ is ground-water inflow; $P$ is direct precipitation; $S W_{\text {out }}$ is the outflow from the reservoir; $G W_{\text {out }}$ is ground-water outflow, $E$ is evaporation from the reservoir surface, and $R$ is an error term. 
The change in storage, $\Delta S$, was calculated from measured stage data and stage-capacity curves developed from available bathymetric contour maps for each of the three Hobbs Brook Reservoir Basins (Fugro East, Inc., 1996) (fig. 2A). $S W_{\text {in }}$ was determined using data from the USGS continuous-record monitoring stations on upper Hobbs Brook (station 01104405 ) and three unnamed tributaries (stations 01104410 , 01104415 , and 01104420). Daily mean streamflows (in meters per second) for each stream (Socolow and others, 1999) were multiplied by the number of seconds in one day and then summed to obtain monthly total volumes (in cubic meters). The monthly streamflow totals then were plotted against subbasin drainage area and the resulting equations used to estimate monthly runoff from the ungaged part of the drainage basin. Daily precipitation totals were obtained from the National Atmospheric Deposition Program/National Trends Network (NADP/NTN) monitoring site MA13 (East) located about $2 \mathrm{~km}$ east of the reservoir (National Atmospheric Deposition Program (NRSP-3)/ National Trends Network, 1999). With very few exceptions, these daily precipitation totals were similar to those measured at a USGS precipitation-monitoring station located at Hanscom Field near Bedford, Mass. (station 01100568 ), about $3 \mathrm{~km}$ northwest of the reservoir. Direct inflows of ground water to the reservoir $\left(G W_{\text {in }}\right)$ were not measured.

$S W_{\text {out }}$ was determined from the Hobbs Brook station downstream from the reservoir (station $01104430)$. $E$ was estimated from monthly mean class-A pan evaporation data reported by the National Weather Service for the period 1956-70 for their observation station at Rochester, Mass., about $85 \mathrm{~km}$ southwest of the reservoir (Farnsworth and others, 1982).

$G W_{\text {out }}$ was not measured. Because ground-water inflows and outflows were not measured during the study, there was no way of determining the relative importance of these flows in the water balance for Hobbs Brook Reservoir. Many water-balance analyses assume that ground-water contributions are accounted for in the residual term. Winter (1981) has shown, however, that the errors associated with the other terms in the water balance can be very large and may misrepresent the ground-water contribution by more than 100 percent.

Results of the water-balance analysis are presented in table 9. The total surface-water inflow to Hobbs Brook Reservoir during water year 1998 was estimated to be $14,400,000 \mathrm{~m}^{3}$. Tributary inflows were proportional to drainage area and were highest in May and June and lowest in September and October. Precipitation was estimated to contribute $2,200,000 \mathrm{~m}^{3}$. Monthly precipitation inputs were small $(61,000$ to $83,200 \mathrm{~m}^{3}$ ) during the first 3 months of the water year, and varied considerably during the remaining 9 months with a maximum precipitation input of $746,000 \mathrm{~m}^{3}$ in June 1998.

Outflow was regulated by the CWD such that the reservoir gained water from November 1997 through June 1998 and then lost water from July through September 1998 (table 9). The 1998 total surface-water outflow was $11,400,000 \mathrm{~m}^{3}$ and the estimated evaporative water loss was $1,350,000 \mathrm{~m}^{3}$. The estimated change in reservoir storage, $1,640,000 \mathrm{~m}^{3}$, was only $60,000 \mathrm{~m}^{3}$ less than the difference between the inputs and outputs, which is the residual.

Because precipitation in the Cambridge drinking-water source area was below normal during the second half of 1997, water levels in the reservoir were extremely low during the first 3 months (October through December) of the study period. The upper basin and part of the middle basin of Hobbs Brook Reservoir were reduced to small streams that presumably consisted mainly of ground-water discharges. The net increase in water storage for the year $\left(1,640,000 \mathrm{~m}^{3}\right)$ reflects this slow refilling of the reservoir.

Hydraulic detention time can be defined as the time it would take for the reservoir to empty out if all inputs of water to the reservoir ceased (Thomann and Mueller, 1987). Dividing the mean reservoir volume for water year $1998\left(5,280,000 \mathrm{~m}^{3}\right)$ by the total outflow for the year $\left(12,700,000 \mathrm{~m}^{3}\right)$ produces an estimated hydraulic detention time of 0.42 years. Previous detention-time estimates for Hobbs Brook Reservoir on the order of 2 years (Fugro East, Inc., 1996) may have been based on an empirical model relating hydraulic detention time to the ratio of drainage area to reservoir surface area (Thomann and Mueller, 1987) and not to any estimate of the actual outflow. The much shorter detention time determined in this study indicates that, for water year 1998 at least, the flushing rate was much higher. Various studies have indicated that, at detention times of less than 60 to 100 days, primary productivity begins to be limited by washout of the phytcplankton (Kimmel and others, 1990). The detention time of Hobbs Brook Reservoir during water year 1998 (150 days) was close to this threshold. 


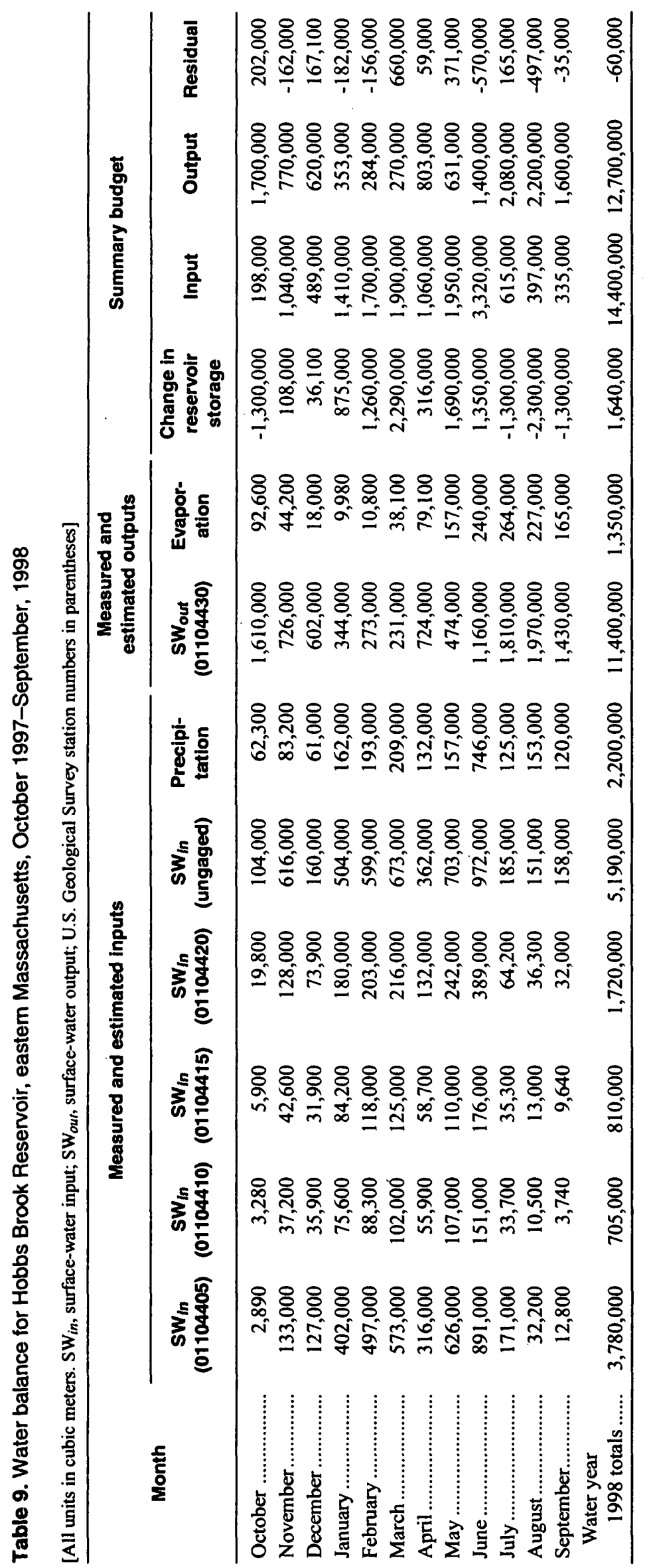


Mass balances for dissolved sodium, total nitrogen total phosphorus, and dissolved manganese entering and leaving Hobbs Brook Reservoir during water year 1998 were calculated based on measured and estimated constituent loads using the equation

$$
\Delta M=M S W_{\text {in }}+M P+M W F-M S W_{\text {out }} \pm R,
$$

where $\Delta M$ is the change in a constituent mass in the reservoir; $M S W_{\text {in }}$ is the input of a constituent from tributary inflows; $M P$ is input of a constituent from direct precipitation; $M W F$ is input of a constituent from waterfowl; $M S W_{\text {out }}$ is output of a constituent from the reservoir; and $R$ is the residual of the mass-balance equation.

Annual (water year 1998) mass balances for each constituent were calculated by summing the massbalance terms from seven shorter measurement periods ranging in length from 5 to 13 weeks. $\Delta M$ for each constituent was calculated by multiplying the changes in reservoir volume determined for each of the seven measuring periods by constituent concentrations measured at various depths at the beginning and end of the measurement periods. $M S W_{\text {in }}$ was calculated for each gaged tributary inflow (stations 01104405, 01104410 , 01104415 , and 01104420 ) by summing the estimated daily mean loads to obtain measuring-period totals for each constituent. Subbasin yields (loads per unit area) were determined for each constituent and the loads entering the reservoir from ungaged parts of the drainage basin were estimated by multiplying the ungaged area by the mean of the corresponding subbasin yields.

$M P$ for sodium was obtained from weekly measurements of dissolved sodium concentrations in precipitation at the NADP/NTN monitoring site just east of the reservoir. These data were multiplied by the corresponding precipitation volumes entering the reservoir and summed over each of the seven measuring periods to obtain measuring-period totals. $M P$ for total nitrogen was obtained by summing concentrations of nitrate and ammonia nitrogen reported for the same precipitation samples (National Atmospheric Deposition Program (NRSP-3)/National Trends Network, 1999). Because data on total phosphorus concentrations in precipitation were not available for the 1998 water year, the mean total phosphorus concentration in wet precipitation samples collected at a USGS precipitation-monitoring station near Concord, Mass. (station 422630071201301), about $6 \mathrm{~km}$ northwest of the reservoir, during water year 1999 (October 1998September 1999), was applied to the precipitation volumes for water year 1998. No attempt was made to estimate masses of constituents entering the reservoir in dry deposition.

$M W F$ was determined based on published information and weekly counts of Canada geese, mallard ducks, herring gulls, cormorants, herons, and other waterfowl (mainly other duck species), made at three observation points on Hobbs Brook Reservoir during water year 1999. Daily per capita rates of excretion of total phosphorus and total nitrogen obtained from the work of Manny and others (1994), for Canada geese, and from Marion and others (1994), for mallards, herring gulls, cormorants, herons, American black ducks, and scaups, were applied to the 1999 counts and used to estimate water year 1998 nutrient loads from waterfowl.

The residual of the constituent-mass-balance equation includes ground-water inflow, ground-water outflow, and storage and release of constituents from bottom sediments. It also includes constituent masses entering the reservoir in dry deposition. Because these components were not measured there is no way to determine their relative importance as sources. The residual represents the net balance of all the unmeasured inputs and outputs plus the net error associated with all the measured and estimated terms. Winter (1981) and LaBaugh and Winter (1984) provide general estimates of the errors associated with similar water and constituent mass balances.

Sodium accumulated in the reservoir water column during water year 1998. The estimated total increase in dissolved sodium mass (based on measured changes in volume and concentration) was $79,000 \mathrm{~kg}$ (table 10). However, the difference between the total surface-water input $(880,000 \mathrm{~kg})$ and the total surfacewater output $(750,000 \mathrm{~kg})$ was $130,000 \mathrm{~kg}$, producing a residual of $-51,000 \mathrm{~kg}$. The subbasins defined by stations 01104415 and 01104420 together contributed 31 percent $(270,000 \mathrm{~kg})$ of the dissolved sodium entering the reservoir. In contrast, precipitation contributed less than 0.1 percent $(460 \mathrm{~kg})$. 
Table 10. Mass balances for dissolved sodium, total nitrogen, total phosphorus, and dissolved manganese for Hobbs Brook Reservoir, eastem Massachusetts, October 1997-September 1998

[SW $W_{i n}$, surface-water input; $S W_{\text {out }}$, surrface-water output. U.S. Geological Survey station numbers in parentheses. --, mass assumed to be negligible; all units in kilograms]

\begin{tabular}{|c|c|c|c|c|c|c|c|}
\hline \multirow[b]{2}{*}{ Constituent } & \multicolumn{7}{|c|}{ Measured and estimated inputs } \\
\hline & $\begin{array}{c}S W_{\text {In }} \\
(01104405)\end{array}$ & $\begin{array}{c}S W_{/ n} \\
(01104410)\end{array}$ & $\begin{array}{c}S W_{/ n} \\
(01104415)\end{array}$ & $\begin{array}{c}S W_{\text {in }} \\
(01104420)\end{array}$ & $\begin{array}{c}S W_{\text {in }} \\
\text { (ungaged) }\end{array}$ & Precipltation & Waterfow \\
\hline Dissolved sodium ......................... & 97,000 & 54,000 & 140,000 & 130,000 & 460,000 & 460 & -- \\
\hline 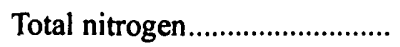 & 2,700 & 300 & 1,100 & 1,800 & 8,600 & 730 & 9 \\
\hline 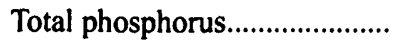 & 79 & 5 & 9 & 23 & 120 & 7 & 4 \\
\hline Dissolved manganese ............... & 210 & 110 & 130 & 160 & 590 & -- & -- \\
\hline
\end{tabular}

\begin{tabular}{|c|c|c|c|c|c|}
\hline \multirow[b]{2}{*}{ Constituent } & \multirow{2}{*}{$\begin{array}{l}\text { Measured } \\
\text { output SW out } \\
(01104430)\end{array}$} & \multicolumn{4}{|c|}{ Summary } \\
\hline & & $\begin{array}{l}\text { Change in } \\
\text { reservoir storage }\end{array}$ & Input & Output & Residual \\
\hline 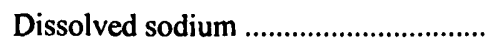 & 750,000 & 79,000 & 880,000 & 750,000 & $-51,000$ \\
\hline 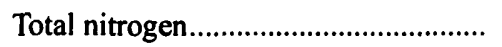 & 4,600 & 630 & 15,000 & 4,600 & $-9,770$ \\
\hline 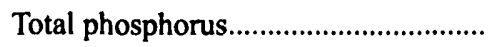 & 130 & -10 & 250 & 130 & -130 \\
\hline Dissolved manganese .............................. & 2,600 & 79 & 1,200 & 2,600 & 1,479 \\
\hline
\end{tabular}

The reservoir acted as a trap for total nitrogen during water year 1998. An estimated $15,000 \mathrm{~kg}$ entered the reservoir, with the contributions from the tributary subbasins roughly proportional to their drainage areas (table 10). The amount entering in precipitation $(730 \mathrm{~kg})$ was more than twice that from the subbasin defined by station $01104410(300 \mathrm{~kg})$. Waterfowl contributed an estimated $9 \mathrm{~kg}$, which was less than 0.1 percent of the total input. Output of total nitrogen in surface water was $4,600 \mathrm{~kg}$, less than one-third of the total input, but very little of the remainder $(630 \mathrm{~kg})$ appeared in storage in the water column, leaving a residual of $-9,770 \mathrm{~kg}$. This result indicates that a large part of the residual total nitrogen was trapped as particulate nitrogen in the reservoir bed sediments.

The reservoir also was a trap for total phosphorus during water year 1998. Only about half of the total input from the drainage basin $(250 \mathrm{~kg})$ was accounted for in the surface-water output (130 kg) (table 10). Loads from tributary subbasins were proportional to drainage area. However, the total-phosphorus contributions from precipitation $(7 \mathrm{~kg})$ and waterfowl $(4 \mathrm{~kg})$ were of similar magnitude to those from stations $01104410(5 \mathrm{~kg})$ and $01104415(9 \mathrm{~kg})$, indicating that precipitation and waterfowl may be at least as signifi- cant as some of the tributary sources of total phosphorus. There was a small decrease in the estimated storage of total phosphorus $(-10 \mathrm{~kg})$ and a large negative residual $(-130 \mathrm{~kg})$, which includes the net effects of both ground-water discharge and internal loading and sedimentation. Data on late summer hypolimnetic phosphorus concentrations (fig. 3) indicate that internal loading from reservoir bed sediments could be an important source. It is unclear, however, from this analysis, how the mass of phosphorus released from the sediments compares with that from the other sources. Dry deposition, which also was not measured in this study, is another potentially important source of phosphorus, especially in oligotrophic lakes (Cole and others, 1990).

In contrast to the other constituents for which mass balances were determined, the water-year 1998 output of dissolved manganese $(2,600 \mathrm{~kg})$ was about twice that of the input $(1,200 \mathrm{~kg})$ and this difference, together with the small increase in storage $(79 \mathrm{~kg})$, produced a positive residual of $1,479 \mathrm{~kg}$ (table 10). The residual term represents the net load of manganese in ground water as well as the net movement into and out of reservoir sediments. 


\section{IMPLICATIONS FOR SOURCE- WATER PROTECTION}

A major purpose of this report is to use the data and results obtained in the previously described investigations of reservoir and tributary stream quality in the Cambridge drinking-water source area to identify reservoir and tributary sampling stations that should be monitored as part of a comprehensive source-water protection program. Monitoring of conditions in drinking-water source areas is an important part of a water-quality management program. The data such a monitoring program provides are both a baseline and an ongoing mechanism for tracking the effects of changing drainage-basin activities. These data also can be used to evaluate the effectiveness of watershed best management practices (BMPs) at ensuring long-term protection of the water supply. Although water treatment can remove most contaminants, it is usually better and more cost effective to prevent contamination of the water supply. There is growing recognition of the value of protecting the high-quality waters that are a source of drinking water as a means of reducing the cost of treatment systems required under the Safe Drinking Water Act (New England Interstate Water Pollution Control Commission, 1996; U.S. Environmental Protection Agency, 1998).

\section{Protection of Reservoir Quality}

Hobbs Brook Reservoir, Stony Brook Reservoir, and especially Fresh Pond are the primary sources of water in the Cambridge drinking-water supply system. Whereas the quality of the water supply is in most respects excellent, the CWD is concerned about higher than desired concentrations of dissolved sodium and chloride, a potential for eutrophication arising from increased inputs of phosphorus and nitrogen, and occasionally high concentrations of dissolved iron and manganese. Also, because there are numerous storm drains discharging highway runoff directly to Hobbs Brook and Stony Brook Reservoirs, there is a constant concern over the possibility of chemical spills and other components of highway runoff.

Median concentrations of dissolved sodium measured during the study period exceeded the USEPA's DWEL guideline of $20 \mathrm{mg} / \mathrm{L}$ in all three reservoirs, ranging from $64 \mathrm{mg} / \mathrm{L}$ in the upper basin of Hobbs Brook Reservoir to 44 and $47 \mathrm{mg} / \mathrm{L}$ in Stony Brook Reservoir and Fresh Pond, respectively. Median concentrations of dissolved chloride never exceeded the USEPA's drinking-water SMCL of $250 \mathrm{mg} / \mathrm{L}$, but were higher in Hobbs Brook Reservoir $(110 \mathrm{mg} / \mathrm{L})$ than in Stony Brook Reservoir $(75 \mathrm{mg} / \mathrm{L})$ or Fresh Pond $(84 \mathrm{mg} / \mathrm{L})$.

There was a distinct seasonal pattern in the reservoir sodium concentrations. In Hobbs Brook Reservoir, the highest measured sodium and chloride concentrations $(82 \mathrm{mg} / \mathrm{L}$ sodium and $150 \mathrm{mg} / \mathrm{L}$ chloride) occurred in early spring and the lowest $(38 \mathrm{mg} / \mathrm{L}$ sodium and $100 \mathrm{mg} / \mathrm{L}$ chloride) occurred in late summer. In Fresh Pond the highest measured sodium and chloride concentrations $(54 \mathrm{mg} / \mathrm{L}$ sodium and $100 \mathrm{mg} / \mathrm{L}$ chloride) occurred in mid-winter and the lowest concentrations $(15 \mathrm{mg} / \mathrm{L}$ sodium and $68 \mathrm{mg} / \mathrm{L}$ chloride) occurred in mid-summer. These results are consistent with the conclusion that winter and spring applications of road salt are the most important source of dissolved sodium and chloride in the drainage basin, that Hobbs Brook Reservoir is more severely affected than Stony Brook Reservoir, and that dilution by water from the Stony Brook subbasin ameliorates the problem to some extent.

The higher median dissolved sodium concentrations in the Hobbs Brook Reservoir Basins are consistent with mass-balance estimates suggesting that station 01104415, which discharges into the upper basin, and station 01104420 , which discharges into the middle basin, together contributed 31 percent of the dissolved sodium entering the reservoir, while contributing only about 18 percent of the water (tables 9 and 10). The estimated dissolved sodium yield from Hobbs Brook $\left(110 \mathrm{~kg} / \mathrm{km}^{2} / \mathrm{d}\right)$, which drains the reservoir, was more than three times that from Stony Brook $\left(32 \mathrm{~kg} / \mathrm{km}^{2} / \mathrm{d}\right)$, which drains the western half of the drainage basin (table 7). Thus, it is likely that dilution by water from Stony Brook and other tributaries supplying Stony Brook Reservoir resulted in lower dissolved sodium concentrations in the two reservoirs downstream from the Hobbs Brook confluence.

Because sodium and chloride are difficult and expensive to remove during conventional water treatment, it will be necessary to monitor concentrations of these ions in the water supply to determine if they are increasing and how they may be responding to management practices, particularly those related to highway 
deicing activities, in the drainage basin. This can be readily accomplished by the use of specific conductance as an indicator of dissolved sodium and chloride concentrations. The most effective location for these monitors would be at the dams on Stony Brook and the lower Hobbs Brook Basin, and near the intake in Fresh Pond. Specific conductance data collected at frequent intervals at these three stations could be converted to concentrations of dissolved sodium and chloride concentrations by means of relations obtained in this investigation. Both short-term and long-term trends could be identified and steps quickly taken to isolate the source of any increases. Tributary loads of dissolved sodium and chloride also need to be monitored closely for the same reasons. Loads from direct precipitation appear not to be an important source of sodium entering the reservoir.

Trophic state indices based on median phytoplankton chlorophyll- $a$ concentrations, median Secchi disk transparencies, and median total phosphorus concentrations indicate that all three reservoirs should be classified as mesotrophic, or moderately productive, and, therefore, susceptible to cultural eutrophication. The three Hobbs Brook Reservoir Basins, with TSIs ranging from 38 to 60 , boarder on the eutrophic, or highly productive, trophic state (table 3 ). Stony Brook Reservoir and Fresh Pond, with TSIs ranging from 27 to 48 , boarder on the oligotrophic, or unproductive, trophic state. More significantly, mean molar ratios of total nitrogen to total phosphorus are extremely high (55 to 102), indicating that phytoplankton growth in the reservoirs is much more likely to be limited by the availability of phosphorus and then by the availability of nitrogen. Thus, small increases in phosphorus loading to the reservoirs could stimulate phytoplankton algae to produce noxious blooms, whereas increases in nitrogen loading probably will not.

Median concentrations of orthophosphate phosphorus in the three reservoirs were only slightly higher than the minimum reporting level of $0.001 \mathrm{mg} / \mathrm{L}$. Median concentrations of total phosphorus, an indicator mainly of living and nonliving particulate phosphorus, decreased from a high of $0.032 \mathrm{mg} / \mathrm{L}$ in the middle basin of Hobbs Brook Reservoir to a low of $0.014 \mathrm{mg} / \mathrm{L}$ in Fresh Pond. This pattern probably is due to sedimentation of organic and inorganic particles in the three basins of Hobbs Brook Reservoir and in Stony Brook Reservoir. Median concentrations of nitrate nitrogen and nitrite nitrogen were significantly (usually more than 10 percent) lower than the USEPA drinking-water MCLs of 10 and $1 \mathrm{mg} / \mathrm{L}$, respectively.

Waterfowl feeding and roosting on the reservoirs are of concern because they are a source of fecal bacteria and also because their feces are rich in phosphorus. The estimated total phosphorus load to Hobbs Brook Reservoir from waterfowl during the study period was similar to those from some of the smaller tributaries and from direct precipitation (table 10). In contrast, the estimated total nitrogen load from waterfowl was less than 1 percent of that from other sources. Given the potential sensitivity of the reservoirs to increased phosphorus loading, it may be necessary to keep track of waterfowl abundances on the reservoirs and take steps to discourage their presence if populations increase.

Median concentrations of dissolved iron rarely exceeded the USEPA drinking water SMCL of $300 \mu \mathrm{g} / \mathrm{L}$. In contrast, the USEPA drinking-water SMCL of $50 \mu \mathrm{g} / \mathrm{L}$ for dissolved manganese was exceeded in Hobbs and Stony Brook Reservoirs but not in Fresh Pond. Naturally occurring iron and manganese is mobilized under anoxic conditions and transported in ground water to streams, where both metals tend to precipitate as oxyhydroxides. Natural organic compounds can act as chelators holding iron and manganese atoms in solution, even under oxidizing conditions (Hem, 1985), and transporting them to the reservoirs. During periods of summer stratification in the reservoirs, manganese goes into solution in the hypolimnion earlier than iron, but is precipitated later than iron when turnover occurs (Stumm and Morgan, 1970). Thus, manganese is more likely to be lost in reservoir outflows and to enter drinking-water intakes than is iron.

On four occasions, surveys of the spatial variability of dissolved oxygen concentration, $\mathrm{pH}$, temperature, and specific conductance were conducted and the data compared with that from the deep hole stations. No consistent spatial trends were observed, indicating that a single depth profile of measurements at the deep hole station could be considered indicative of conditions throughout the reservoir. It should be noted, however, that these comparisons were done only during periods when there was no ice cover. During the winter deicing season, and especially under ice cover, there may be horizontal variations in sodium and chloride concentrations related to the discharge of highway runoff directly to the reservoirs. The deep hole stations in the three main basins, together with stations on the 
upper and middle basins of Hobbs Brook Reservoir, can be considered as secondary reservoir-monitoring stations in addition to the three primary stations described earlier. Additional secondary reservoirmonitoring stations should be established in the upper and middle basins of Hobbs Brook Reservoir.

\section{Protection of Tributary-Stream Quality}

A second level of monitoring for protection of the Cambridge drinking-water supply involves the tributaries that contribute water directly or indirectly to the reservoirs. The investigation of tributary-stream quality previously described estimated contaminant loads for water year 1998 at 10 tributary-monitoring stations and examined the effects of land use and other drainage-basin features on contaminant yields from the subbasins defined by these stations. These analyses provided the information needed to justify incorporation of the stations into a permanent water-qualitymonitoring network. In the following discussion, each tributary-monitoring station is characterized in terms of its relative contribution to the total loads of contaminants entering the water supply and its proximity to the reservoir. The 10 stations can be considered as primary tributary-monitoring stations, indicative of the quality of water entering the reservoirs.

\section{Hobbs Brook at Mill Street near Lincoln, Mass. (01104405)}

Hobbs Brook is one of three tributaries that convey water directly to the upper basin of Hobbs Brook Reservoir. The subbasin defined by station 01104405 (Hobbs Brook at Mill Street, near Lincoln, Mass.), at $5.59 \mathrm{~km}^{2}$, is by far the largest of the three. During water year 1998, the subbasin was a major source of phosphorus, dissolved iron, and DOC to the water supply. Median concentrations of DOC were higher at station 01104405 than at any other station in the drainage basin. The subbasin also produced high yields of total phosphorus, dissolved iron, DOC, and THMFP, relative to the other subbasins in the source area (table 7). These high concentrations and yields probably are related to the relatively large percent wetland cover in the subbasin (table 5). Wetlands are a source of DOC, which increases the solubility of iron by forming organic-iron complexes, and anoxic water, which impedes formation of insoluble inorganicphosphorus complexes. Phosphorus is the most important constituent in this tributary with respect to its potential effect on the Hobbs Brook Reservoir.

\section{Cambridge Reservoir, Unnamed Tributary 1, near Lexington, Mass. (01104410)}

The subbasin defined by station 01104410 (Cambridge Reservoir, Unnamed Tributary 1, near Lexington, Mass.) contributed more dissolved iron per square kilometer than any subbasin in the source area. In addition, the highest median concentrations of fecal coliform bacteria, orthophosphate phosphorus, and dissolved iron were measured at the station. The percentage of floodplain alluvium in the subbasin is more than five times that of any other subbasin in the source area (table 5) and this may account for the high median concentrations of orthophosphate phosphorus and iron, since a high proportion of streamflow in the tributary enters as anoxic ground water rich in these constituents.

\section{Cambridge Reservoir, Unnamed Tributary 2, near Lexington, Mass. (01104415)}

The subbasin defined by station 01104415 (Cambridge Reservoir, Unnamed Tributary 2, near Lexington, Mass.) was the greatest source of contamination in the drainage basin during water year 1998. Median concentrations of dissolved sodium and chloride, total nitrogen, and dissolved manganese were higher at that station than at any other station in the source area, and median concentrations of ammonia nitrogen, nitrate nitrogen, and total nitrogen exceeded national background concentrations reported by the USGS National Water-Quality Assessment (NAWQA) Program (U.S. Geological Survey, 1999) for undisturbed stream sites. Subbasin yields of sodium and chloride were larger at station 01104415 than at any other subbasin and the subbasin also produced relatively large yields of dissolved manganese, dissolved iron, nitrate nitrogen, and total nitrogen (table 7). Although the subbasin contributed less than 6 percent of the water entering Hobbs Brook Reservoir during water year 1998 , it contributed nearly 16 percent of the dissolved sodium (table 10). 
It is likely that much of the contamination is related to highway runoff. More than 13 percent of the subbasin is covered by roads, the highest coverage of any subbasin in the source area (table 5). The subbasin includes a major highway interchange connecting State Routes $2 \mathrm{~A}$ and 128 and a salt storage area managed by MassHighway. The subbasin also contains a large proportion of medium-density residential land use, but most of this land is not directly associated with the tributary. State highways occupy twice as much of the subbasin as they do in any other subbasin (table 5) and are located in close proximity to the station, the tributary, and the reservoir (fig. 6). Inclusion of this station in a water-quality monitoring program is essential because of the serious potential for increased contributions of sodium and other contaminants to the water supply.

\section{Cambridge Reservoir, Unnamed Tributary 3, near Lexington, Mass. (01104420)}

Station 01104420 (Cambridge Reservoir, Unnamed Tributary 3, near Lexington, MA) is on a small unnamed tributary that enters the middle basin of Hobbs Brook Reservoir. The tributary receives runoff from State Routes 2 and 128 and from a commercial parking lot and also drains a wetland area east of Route 128 (fig. 6). Maximum concentrations of fecal coliform bacteria measured at the station were the highest of any in the source area and median concentrations of ammonia nitrogen and total nitrogen exceeded national background concentrations reported by the USGS National Water-Quality Assessment (NAWQA) Program (U.S. Geological Survey, 1999) for undisturbed stream sites.

\section{Hobbs Brook, Unnamed Tributary 1, near Kendal Green, Mass. (01104433)}

Station 01104433 (Hobbs Brook, Unnamed Tributary 1, near Kendal Green, MA) is on a small tributary that enters Hobbs Brook about $1 \mathrm{~km}$ downstream from the dam. The subbasin drains a small forested wetland (fig. 6) and has the greatest densities of commercial and industrial land use of any subbasin in the source area (table 5). Median concentrations of ammonia nitrogen and total nitrogen measured at the station exceeded national background concentrations (U.S. Geological Survey, 1999) and the median concentration of dissolved manganese was the highest measured in the source area. Because there were problems estimating daily mean discharges at this station, no constituent loads or subbasin yields were calculated. Consequently, direct comparisons with other subbasins are not possible. Nonetheless, there appears to be a potential for significant contaminant transport from this subbasin. However, the wetland in the subbasin and a small ponded area downstream from the station probably reduce the potential for serious contamination of Hobbs Brook. The tributary should be monitored, especially as commercial and industrial development continues in the subbasin.

\section{Hobbs Brook at Kendal Green, Mass. (01104440)}

Station 01104440 (Hobbs Brook at Kendal Green, Mass.) is important because it integrates water and constituent loads from the entire Hobbs Brook subbasin. The station is located just upstream from the confluence of Hobbs Brook and Stony Brook and affords useful comparisons with monitoring data collected at station 01104390 on Stony Brook (Stony Brook at Kendal Green, Mass.) nearby. Streamflow and water quality at the Hobbs Brook station reflected the operation and condition of the reservoir upstream during water year 1998. That is, the water quality generally was very good, and yields of most measured constituents were consistent with those from the other smaller subbsins and from the larger Stony Brook subbasin (table 7). Exceptions were the estimated subbasin yields of fecal coliform bacteria, dissolved manganese, and THMFP, each of which were larger than most other subbasins.

\section{Stony Brook at Kendal Green, Mass. (01104390)}

Station 01104390 (Stony Brook at Kendal Green, Mass.) is located on Stony Brook just upstream from its confluence with Hobbs Brook (fig. 6). As such, water-quality data from the station integrates and represents conditions in a subbasin comprising more than half the total source area. The subbasin area is similar to that above station 01104440 . Land use and land cover, however, are appreciably different in the two integrator subbasins. The Stony Brook subbasin contains significantly less commercial and industrial land (0.4 percent for Stony Brook and 8.4 percent for Hobbs Brook), far smaller amounts of State-maintained roads ( 0.4 and 2.2 percent, respectively), and a larger amount of low-density residential land use ( 35 versus 13 percent) (table 5). Both subbasins produced relatively 
large estimated yields for fecal coliform bacteria (table 7). However, estimated subbasin yields for sodium, chloride, manganese, total phosphorus, and THMFP all were larger in the Hobbs Brook subbasin than they were in the Stony Brook subbasin. Nonetheless, continued monitoring at station 01104390 will provide a good indication of any major changes in land use and management in the upstream subbasin.

\section{Stony Brook, Unnamed Tributary 1, near Waltham, Mass. (01104455)}

Station 01104455 (Stony Brook, Unnamed Tributary 1, near Waltham, Mass.) discharges through a small nonforested wetland to Stony Brook about $0.7 \mathrm{~km}$ upstream from Stony Brook Reservoir (fig. 6). The subbasin defined by the station contains significant amounts of State and locally-maintained roads, and commercial and industrial land use (table 5). Much of the lower part of the subbasin is paved and this part of the stream is routed through culverts that directly drain State Route 128 and the interchange connecting State Routes 20 and 128 . Also a large amount of high-density and multi-family residential land use relative to other subbasins is present in the source area (table 5).

During water year 1998, median concentrations of ammonia nitrogen, nitrate nitrogen, and total nitrogen exceeded national background concentrations (U.S. Geological Survey, 1999) and median concentrations of dissolved sodium and orthophosphate phosphorus were high relative to those of other subbasins in the source area. The State standard for fecal coliform bacteria in Class A streams ( $20 \mathrm{CFU} / 100 \mathrm{~mL})$ was exceeded every time the stream was sampled during water year 1998.

The subbasin produced the largest yields of fecal coliform bacteria, nitrate nitrogen, total nitrogen, and total phosphorus of any subbasin in the source area (table 7). Because of its proximity to Stony Brook Reservoir, constituent loads from this subbasin may have affected the quality and trophic state of the reservoir. Furthermore, the large amount of impermeable surface area in the subbasin near the monitoring station resulted in very rapid increases in discharge in response to precipitation and stormwater runoff. For these reasons, monitoring at this station would benefit from installation of continuous stage and specific conductance recorder and a system for automatically sampling the stream when stage or specific conductance change significantly. Sampling for additional constituents indicative of contamination from highway runoff (total petroleum hydrocarbons, total suspended solids, trace metals, and certain volatile organic carbon compounds) would provide a more complete picture of the effects of the highway on this tributary.

\section{Stony Brook at Route 20 near Waltham, Mass. (01104460)}

Station 01104460 (Stony Brook at Route 20 near Waltham, Mass.) effectively integrates the main part of the source area upstream from Stony Brook Reservoir (fig. 6). Most of the water that enters Stony Brook Reservoir flows past this station. Median concentrations and estimated subbasin yields of nearly all constituents measured during water year 1998 were either low or at most moderate relative to other subbasins in the source area (table 7). Regular monitoring at this station will provide important information on the quality of water entering Stony Brook Reservoir and help guide management of the reservoir.

\section{Stony Brook Reservoir, Unnamed Tributary 1, near Weston, Mass. (01104475)}

\section{Station 01104475 (Stony Brook Reservoir,} Unnamed Tributary 1, near Weston, Mass) is located on a small, unnamed tributary that discharges directly into Stony Brook Reservoir near the dam (fig. 6). Land use in the subbasin defined by the station is considerably different from that in most other subbasins in the source area (table 5). The subbasin contains relatively little forest compared to the other subbasins, and there are no State-maintained roads, no commercial or industrial land use. The predominant land use is low-density residential. The tributary's contribution to the total flow of water through the system was small during water year 1998 (table 7), but the location of its outfall close to the water-supply intake makes it an important station to monitor. During water year 1998, median concentrations of fecal coliform bacteria, sodium, chloride, ammonia nitrogen, and dissolved iron and manganese were the lowest of any in the source area. Subbasin yields of fecal coliform bacteria, sodium, chloride, and manganese were much smaller than those of the other 
subbasins. During the same period, however, median concentrations of nitrate nitrogen and total nitrogen were higher than published national background concentrations for undisturbed streams (U.S. Geological Survey, 1999), and subbasin yields of nitrate nitrogen, total phosphorus, and THMFP were larger than those of most other subbasins (table 7). The high concentrations and large yields of nutrients probably reflect fertilizer use in the largely residential subbasin, and may be related to the presence of a golf course.

Thus, the station can serve as a control for the effects of road deicing on sodium and chloride loads, but should be considered an important source of nutrients to Stony Brook Reservoir and possibly to Fresh Pond.

\section{SUMMARY AND CONCLUSIONS}

Assessments of reservoir and tributary-stream quality were conducted in the Cambridge, Mass., drinking-water source area to help guide development of a comprehensive water-quality monitoring program for the source area. Limnological assessments of the three primary storage reservoirs, Hobbs Brook Reservoir, Stony Brook Reservoir, and Fresh Pond, were conducted to provide baseline information on the state of these resources and to determine the vulnerability of the reservoirs to increased loads of nutrients and other contaminants. The effects of land use, land cover, and other drainage-basin characteristics on transport and fate of highway deicing chemicals, nutrients, naturally occurring organic compounds, fecalindicator bacteria, and selected metals within the source area were examined and ranked statistically. Results of these investigations were used to select monitoring stations to be included in a long-term water-quality monitoring network for the source area.

Representative sampling stations were established on the three reservoirs and sampling for physical, chemical, and biological characteristics was carried out over a period of 14 months, beginning in September 1997 and continuing through November 1998. Reservoir bed sediments were examined once at the end of the study period for the presence of 27 trace metals and other constituents, and data on nutrient concentrations, water-column transparency, and phytoplankton abundance were used to calculate trophic state indices for each of the reservoirs.

Sources of fecal coliform bacteria, dissolved sodium and chloride, nitrate nitrogen, total nitrogen, total phosphorus, dissolved iron, dissolved manganese, DOC, and THMFP entering Hobbs Brook and Stony Brook Reservoirs were identified and quantified by estimating mean daily loads at key points in the drainage system during water year 1998 (October 1997September 1998). These load estimates were then normalized to the areas of the subbasins defined by the sampling stations and the resultant subbasin yields related statistically to land use, land cover and other characteristics of the subbasins. The estimated sodium, total nitrogen, total phosphorus, and dissolved manganese loads were combined with data on stage and bathymetry of Hobbs Brook Reservoir and used to determine mass balances for these constituents in the reservoir.

Data and other information gained in the assessments of reservoir and tributary quality were used to select reservoir and tributary monitoring stations for inclusion in a water-quality monitoring program designed to ensure long-term protection of the water supply and delivery of high quality water for treatment or distribution.

Seasonal thermal and chemical stratification were observed in all three reservoirs during the study period. Hobbs Brook Reservoir was thermally stratified from early June through September 1998, and the hypolimnion was anoxic below a depth of $4 \mathrm{~m}$ from late July through September 1998. Under these conditions, ammonia nitrogen, orthophosphate phosphorus, and dissolved manganese were released from the sediments and accumulated in the hypolimnion. The main basin of Stony Brook Reservoir was artificially mixed during the study period. However, a small deep hole resulted that was thermally and chemically isolated from the rest of the water column in September 1997, and from early March through November 1998. Water samples collected near the bottom at this station in September 1997 contained the highest concentrations of total nitrogen $(3.7 \mathrm{mg} / \mathrm{L})$ and ammonia nitrogen $(2.3 \mathrm{mg} / \mathrm{L})$ and the second highest concentration of dissolved manganese $(6.27 \mathrm{mg} / \mathrm{L})$ measured in any of the reservoirs during the study period. Fresh Pond also was 
artificially mixed during most of the study period. Despite the mixing, however, there were losses of dissolved oxygen in late summer 1998 in the deepest parts of the pond, and these were accompanied by releases of dissolved manganese. A sample of this hypolimnetic water collected in late August 1998 contained the highest concentration of dissolved manganese $(12.7 \mathrm{mg} / \mathrm{L})$ measured duruing the study. Nutrients released in the hypolimnia of the reservoirs during summer stratification have the potential to stimulate algal growth when the water column mixes at turnover, and manganese released under hypoxic conditions in the deep holes of Fresh Pond is likely to remain in solution.

Median concentrations of dissolved sodium measured during the study period exceeded the USEPA's DWEL guideline of $20 \mathrm{mg} / \mathrm{L}$ in all three reservoirs and generally were higher in Hobbs Brook Reservoir than Stony Brook Reservoir or Fresh Pond. Median concentrations of dissolved chloride never exceeded the USEPA's drinking-water SMCL of $250 \mathrm{mg} / \mathrm{L}$, but were higher in Hobbs Brook Reservoir than in Stony Brook Reservoir or Fresh Pond. There was a distinct seasonal pattern of sodium and chloride concentrations, with highest concentrations of both ions appearing in the winter and spring, and lowest concentrations appearing in summer and autumn. These results are consistent with the conclusion that winter and spring applications of road salt are the most significant sources of dissolved sodium and chloride in the drainage basin, that Hobbs Brook Reservoir is more severely affected than Stony Brook Reservoir, and that dilution by water from the Stony Brook subbasin ameliorates the problem to some extent.

Dissolved organic carbon concentrations increased somewhat during the summer months and decreased in the autumn and winter. However, even during the summer period of summer stratification, the DOC was uniformly distributed with depth. In contrast, THMFP decreased in the anoxic hypolimnion during summer stratification. The range of THMFP concentrations measured in the reservoirs $(0.055$ to $0.366 \mathrm{mg} / \mathrm{L})$ was similar to that reported in the literature for surfacewater supplies in North Carolina and Arkansas (Singer and others, 1981; Pomes and others, 1999).

Concentrations of trace metals in Stony Brook Reservoir bed sediments were higher than those in Hobbs Brook Reservoir and were either higher than or similar to median concentrations of the same metals measured at 135 bed-sediment sampling stations in the lower Charles River Basin. The concentration of phosphorus in Stony Brook sediments was three times that of the other reservoirs in the Cambridge drinking-water supply system and nearly twice that of the lower Charles River Basin. When sediment trace metal concentrations were normalized to the concentration of aluminum to remove the effects of differential deposition rates, the normalized concentrations generally were higher in the lower Charles River Basin than in either Hobbs Brook or Stony Brook Reservoirs. Normalized concentrations of arsenic, iron, and manganese, however, were higher in the three Cambridge Reservoirs than in the lower Charles River Basin, indicating possible localized sources for these metals. Normalized total phosphorus concentrations were similar in all samples.

Trophic state indices calculated for the reservoirs ranged from the high 40's in Hobbs Brook Reservoir to a minimum of 27 in Fresh Pond. In general, the reservoirs in the upper part of the water-supply system were more eutrophic than those in the lower part of the system. The upper and middle basins of Hobbs Brook Reservoir had the highest TSI values, indicating that these basins are moderately to highly productive and likely to produce algal blooms; the lower basin of Hobbs Brook Reservoir and Stony Brook Reservoir were similar and intermediate in TSI value, and Fresh Pond had the lowest values, ranging from moderately productive to unproductive, and unlikely to produce algal blooms. This pattern is due mainly to sedimentation of organic and inorganic particles in the three basins of Hobbs Brook Reservoir and in Stony Brook Reservoir. Nitrogen-to-phosphorus ratios in the reservoirs ranged from 55 in Stony Brook Reservoir to 120 in Hobbs Brook Reservoir, indicating that these water bodies may be phosphorus limited and that small increases in phosphorus loading to the reservoirs could stimulate algae to produce noxious blooms.

Concentrations of fecal coliform bacteria in water samples collected at 11 tributary-monitoring stations in the Cambridge drinking-water source area frequently exceeded the State standard of $20 \mathrm{CFU} / 100 \mathrm{~mL}$ for Class A streams. Concentrations were highest (up to $1,700 \mathrm{CFU} / 100 \mathrm{~mL}$ ) in samples collected during storms. Estimated subbasin yields for 
fecal coliform bacteria were largest in the subbasin defined by station 01104455 and for the two stations representing integrator stations for the Stony Brook (station 01104390 ) and Hobbs Brook (station 01104440 ) subbasins.

Concentrations of dissolved sodium and chloride were highest at stations 01104410,01104415 , 01104420 , and 01104455 , all of which are heavily affected by State-maintained roads. It is likely that State-maintained roads had a greater effect than locally maintained roads on yields of sodium and chloride in the source area. The estimated annual mean loads of sodium and chloride for the Hobbs Brook integrator station (station 01104440) were about three times greater than those for the Stony Brook integrator station (station 01104390), although the drainage areas differ only by about 21 percent. The areal coverage of locally maintained roads is 3.2 percent for the Hobbs Brook subbasin and 2.2 percent for the Stony Brook subbasin. The percent coverage of State-maintained roads, however, is much higher in the Hobbs Brook subbasin (4.3 percent) than it is in the Stony Brook subbasin ( 0.4 percent). The Hobbs Brook drainage also contains more commercial and industrial land than the Stony Brook drainage, but these land uses were not correlated with sodium and chloride yields.

The Hobbs Brook subbasin and the Stony Brook subbasin produced similar estimated annual mean loads for nitrate nitrogen and total nitrogen. Subbasin yields of the two nitrogen species were similar, and were comparable in magnitude to those determined for the combined drainage basin upstream from station 01104460 . Little station-to-station variability resulted in median orthophosphate phosphorus concentrations. The estimated total phosphorus load at the Hobbs Brook integrator station was nearly twice that at the Stony Brook integrator station. In general, however, phosphorus yields were small throughout the drainage basin.

The Hobbs Brook and Stony Brook subbasins produced similar estimated annual mean loads for iron. The estimated annual mean manganese load from the Hobbs Brook subbasin, however, was greater than that from the Stony Brook subbasin.

The median concentration of DOC was highest in samples from station 01104405 , which drains a large red maple swamp, and lowest in samples from station
01104455, which drains a small subbasin with large amounts of paved area and almost no wetland area. Median concentrations of THMFP ranged from $0.085 \mathrm{mg} / \mathrm{L}$ at station 01104455 to $0.273 \mathrm{mg} / \mathrm{L}$ at the mouth of Hobbs Brook (station 01104440). Maximum concentrations were more uniform, ranging from $0.204 \mathrm{mg} / \mathrm{L}$ at station 01104455 to $0.370 \mathrm{mg} / \mathrm{L}$ at station 01104390 . The USEPA drinking-water standard is $0.080 \mathrm{mg} / \mathrm{L}$. Estimated annual mean yields of DOC and THMFP were remarkably uniform, suggesting that no subbasin was exporting a disproportionate amount of either constituent on an annual basis. One exception was station 01104405, where the estimated DOC yield was two to three times greater than those of the other stations.

A hydraulic detention time of 0.42 years was determined for Hobbs Brook Reservoir during water year 1998. Previous detention-time estimates for Hobbs Brook Reservoir were on the order of 2 years. The much shorter detention time determined in this study suggests that, for water year 1998 at least, the flushing rate was much higher and therefore, the capability of the reservoir to assimilate nutrient loads was greater than previously determined.

Sodium accumulated in Hobbs Brook Reservoir during water year 1998. Larger amounts̀ of sodium were contributed by the subbasins represented by stations 01104415 and 01104420 than would be expected based on their drainage areas and contributions to the water balance. In contrast, precipitation, which accounted for 31 percent of water entering the reservoir, contributed only about 0.05 percent of the sodium.

The reservoir was a trap for total nitrogen during water year 1998. An estimated 15,000 kg entered the reservoir, with the contributions from the tributary subbasins roughly proportional to their drainage areas. The amount entering in precipitation was more than twice that from the subbasin defined by station 01104410 . Waterfowl contributed an estimated $9 \mathrm{~kg}$, which was less than 0.1 percent of the total input. Output of total nitrogen in surface water was $4,600 \mathrm{~kg}$, less than onethird of the total input, but very little of the remainder $(630 \mathrm{~kg})$ appeared in storage in the water column. It is possible that a large part of the residual total nitrogen was trapped as particulate nitrogen in the reservoir sediments. 
The reservoir also apparently was a trap for total phosphorus during water year 1998. Only about half of the total input from the drainage basin $(250 \mathrm{~kg})$ was accounted for in the surface-water output $(130 \mathrm{~kg})$. Loads from tributary subbasins were proportional to drainage area. However, the total-phosphorus contributions from precipitation $(7 \mathrm{~kg}$ ) and waterfowl $(4 \mathrm{~kg})$ were of similar magnitude to those from stations $01104410(5 \mathrm{~kg})$ and $01104415(9 \mathrm{~kg})$, indicating that precipitation and waterfowl may be at least as significant as some of the tributary sources of total phosphorus.

Based on the results obtained from these investigations, 10 of the 11 tributary-monitoring stations were selected for inclusion as primary tributary-monitoring stations in a source-area water-quality monitoring network developed jointly by the USGS and the CWD. These stations represent streams that contribute water either directly to the reservoirs and major tributaries, or integrate large areas of the drainage basin. Criteria for inclusion in the network were the magnitudes of actual or potential contaminant loads and the proximity of the monitoring stations to the reservoirs. In addition, eight monitoring stations representative of water-quality and trophic conditions in Hobbs Brook Reservoir, Stony Brook Reservoir, and Fresh Pond were identified and incorporated into the network. Details of the monitoring network are included in an appendix to this report.

\section{REFERENCES CITED}

American Public Health Association, American Water Works Association, and Water Pollution Control Association, 1995, Standard methods for the examination of water and wastewater (19th ed.): Washington, D.C., American Public Health Association, variously paginated.

Bingham, D.R., 1998, Watershed management in U.S. urban areas, in Reimold, R.J. (ed.), Watershed management. practices, policies, and coordination: New York, McGraw-Hill, p. 169-201

Carlson, R.E., 1977, A trophic state index for lakes: Limnology and Oceanography, v. 22, no. 2, p. 361-369.
Church, P.E., Armstrong, D.S., Granato, G.E., Stone, V.J., Smith, K.P., and Provencher, P.L., 1996, Effectiveness of highway-drainage systems in preventing contamination of ground water by road salt, Route 25 , southeastern Massachusetts-description of study area, data collection programs, and methodology: U.S. Geological Survey Open-File Report 96-317, 72 p.

Cohn, T.A., Caulder, D.L., Gilroy, E.J., Zynjuk, L.D., and Summers, R.M, 1992, The validity of a simple statistical model for estimating fluvial constituent loads-An empirical study involving nutrient loads entering Chesapeake Bay: Water Resources Research, v. 28 , no. 9, p. 2353-2363.

Cohn, T.A., DeLong, L.L., Gilroy, E.J., Hirsch, R.M., and Wells, D.K., 1989, Estimating constituent loads: Water Resources Research, v. 25, no. 5, p. 937-942.

Cole, J.J, Caraco, N.F., and Likens, G.E., 1990, Short-range atmospheric transport-a significant source of phosphorus to an oligotrophic lake: Limnology and Oceanography, v. 35, no. 6, p. 1230-1237.

Colman, J.A., and Breault, R.F., 2000, Sampling for mercury at subnanogram per litre concentrations for load estimation in rivers: Canadian Journal of Fisheries and Aquatic Sciences, v. 57, p. 1073-1079.

Cooke, G.D., Welch, E.B., Peterson, S.A., and Newroth, P.R., 1993, Restoration and management of lakes and reservoirs (2d ed.): New York, Lewis Publishers, $548 \mathrm{p}$.

Duan, Naihua, 1983, Smearing estimate-A nonparametric retransformation method: Journal of the American Statistical Association, v. 78, p. 605-610.

Edwards, T.K., and Glysson, G.D., 1999, Field methods for measurement of fluvial sediment: U.S. Geological Survey Techniques of Water-Resources Investigations, book 3, chap. C2, $89 \mathrm{p}$.

Farnsworth, R.K., Thompson, E.S., and Peck., E.L., 1982, Evaporation atlas for the contiguous 48 United States: Washington, D.C., National Weather Service, Office of Hydrology, $26 \mathrm{p}$.

Fishman, M.J., and Friedman, L.C., eds., 1989, Methods for determination of inorganic substances in water and fluvial sediments: U.S. Geological Survey Techniques of Water-Resources Investigations, book 5, chap. A1, $545 \mathrm{p}$.

Fugro East, Inc., 1996, Limnological investigations of the Cambridge Reservoir system-Impacts of watershed inputs and alum sludge discharge: Cambridge, Mass., Cambridge Water Department, 77 p. plus Appendixes.

Geotechnical Engineers, Inc., 1985, Hobbs Brook Reservoir sodium chloride study: Geotechnical Engineers, Inc., variously paginated. 
Gilroy, E.J., Hirsch, R.M., and Cohn, T., 1990, Mean square error of regression-based constituent transport estimates: Water Resources Research, v. 26, no. 9, p. 2069-2077.

Godfrey, P.J., and Kerr, P.A., 2000, Preliminary evaluation of a promising forced air-drying technique for preserving chlorophyll on glass-fiber filters: Lake and Reservoir Management, v. 16, no. 3, p. 222-234.

Granato, G.E., 1995, Deicing chemicals as source of constituents of highway runoff: Transportation Research Record 1533, p. 50-58.

Granato, G.E. Church, P.E., and Stone, V.J., 1995, Mobilization of major and trace constituents of highway runoff in groundwater potentially caused by deicing chemical migration: Transportation Research Record 1483, p. 92-104.

Harper, C.R., Goetz, W.J., and Willis, C.E., 1992, Groundwater protection in mixed land-use aquifers:

Environmental Management, v. 16, no. 6, p. 777-783.

Hem, J.D., 1992, Study and interpretation of the chemical characteristics of natural water (3d ed.): U.S. Geological Survey Water-Supply Paper 2254, 263 p.

Hirsch, R.M., 1982, A comparison of four streamflow record extension techniques: Water Resources Research, v. 18, no. 4 , p. 1081-1088.

Horowitz, A.J., 1991, A primer on sediment-trace element chemistry ( $2 \mathrm{~d}$ ed.), Chelsea, Mich., Lewis Publishers, $136 \mathrm{p}$.

Intergovernmental Task Force on Monitoring Water Quality, 1995, The strategy for improving water-quality monitoring in the United States, Final report of the Intergovernmental Task Force on Monitoring Water Quality: Reston, Va., U.S. Geological Survey, Office of Water Data Coordination, 25 p. plus Appendixes.

Kachigan, S.K., 1986, Statistical analysis. An interdisciplinary introduction to univariate and multivariate methods: New York, Radius Press, 599 p.

Kennedy, E.J., 1984, Stage measurements at discharge stations. U.S. Geological Survey Techniques of WaterResources Investigations, book 3, chap. A10, 59 p.

Kimmel, B.L., Lind, O.T., and Paulson, L.J., 1990, Reservoir primary production, in Thornton, K.W., Kimmel, B.L., and Payne, F.E. (eds.), Reservoir limnologyEcological perspectives: New York, John Wiley and Sons, p. 133-193.

Krasner, S.W., Sclimenti, M.J., and Means, E.G., 1994, Quality degradation-Implications for DBP formation: Journal of the American Water Works Association, June 1994 , p. $34-47$.
LaBaugh, J.W., 1985, Uncertainty in phosphorus retention, Williams Fork Reservoir, Colorado: Water Resources Research, v. 21, no. 11, p. 1684-1692.

LaBaugh, J.W., and Winter, T.C., 1984, The impact of uncertainties in hydrologic measurements on phosphorus budgets and empirical models for two Colorado Reservoirs: Limnology and Oceanography, v. 29 , no. 2 , p. $322-339$.

Lee, G.F., Jones, R.A., and Rast, W., 1981, Index to evaluate lake restoration: Journal of the Environmental Engineering Division ASCE, v. 107, p. 1334-1336.

Manny, B.A., Johnson, W.C., and Wetzel, R.G., 1994, Nutrient additions by waterfowl to lakes and reservoirs-their effects on productivity and water quality: Hydrobiologia, v. 279/280, p. 121-132.

Marion, Loic, Clergeau, Phillipe, Brient, Luc, and Bertu, Georges, 1994, The importance of avian-contributed nitrogen $(\mathrm{N})$ and phosphorus $(\mathrm{P})$ to Lake Grand-Lieu, France: Hydrobiologia, v. 279/280, p. 133-147.

Massachusetts Highway Department, 1997, Draft environmental impact report-Volumes I, II, and III, Hobbs Brook and Stony Brook watersheds highway drainage improvement project EOEA number 8263 , variously paginated.

Mattson, M.D., and Godfrey, P.J., 1994, Identification of road salt contamination using multiple regression and GIS: Environmental Management: v. 18 , no. 5, p. 767773.

Moore, R.A., and Barbaro, H.L., 1998, Role of highways in watershed planning, in Reimold, R.J. (ed.), Watershed management. practice, policies, and coordination: New York, McGraw-Hill, 391 p.

National Atmospheric Deposition Program (NRSP3)/National Trends Network, 1999, NADP Program Office, Illinois State Water Survey: Champaign, Ill., accessed December 10, 1999, at URL http://nadp.sws.uiuc.edu/nadpdata/siteinfo.asp?id=MA 13\&net=NADP.

National Oceanic and Atmospheric Administration, 1998, Climatological data annual summary-New England 1997: Ashville, N.C., National Climatic Data Center, v. 109 , no. 13 .

National Oceanic and Atmospheric Administration, 1999, Climatological data annual summary-New England 1998: Ashville, N.C., National Climatic Data Center, v. 110, no. 13 . 
New England Interstate Water Pollution Control Commission, 1996, Source protection-A guidance manual for small surface water supplies in New Englånd: New England Interstate Water Pollution Control Commission, 77 p. plus Appendixes.

Patterson, Glenn, 1997, The U.S. Geological Survey Drinking Water Initiative: U.S. Geological Survey Fact Sheet 047-97, $2 \mathrm{p}$.

Pomes, M.L., Green, W.R., Thurman, E.M., Orem, W.H., and Lerch, H.E., 1999, DBP formation potential of aquatic humic substances: Journal of the American Water Works Association, v. 91, no. 3, p.103-115.

Pritt, J.W., and Raese, J.W., 1992, Quality assurance/quality control manual. National Water Quality Laboratory: U.S. Geological Survey Open-File Report 92-495, 33 p.

Rantz, S.E., and others, 1982, Measurement and computation of streamflow-Volume 1. Measurement of stage and discharge-Volume 2. Computation of discharge: U.S. Geological Survey Water-Supply Paper $2175,631 \mathrm{p}$.

Reckhow, K.H., 1979, Quantitative techniques for the assessment of lake quality: Washington, D.C., U.S. Environmental Protection Agency, Office of Water Planning and Standards, Report No. EPA-440/5-79$015,146 \mathrm{p}$.

Reckhow, D.A., Singer, P.C., and Malcolm, R.L., 1990, Chlorination of humic materials-Byproduct formation and chemical interpretations: Environmental Science and Technology, v. 24, no. 11, p. 1655-1664.

Reinelt, L.E., Horner, R.R., and Mar, B.W., 1988, Nonpoint source pollution monitoring program design: Journal of Water Resources Planning and Management, v. 114, no. 3, p. 335-352.

Singer, P.C., Barry, J.J., Palen, G.M., and Scrivner, A.E., 1981, Trihalomethane formation in North Carolina drinking waters: Journal of the American Water Works Association, v. 73, no. 8, p. 392-401.

Socolow, R.S., Comeau, L.Y., Zanca, J.L., and Ramsbey, L.R., 1999, Water-resources data for Massachusetts and Rhode Island, water year 1998: U.S. Geological Survey Water-Data Report MA-RI-98-1, 438 p.

Stephens, T.L., and Shiller, A.M., 1999, Temperaturedependent microbial control of dissolved manganese in the lower Mississippi River: American Society of Limnology and Oceanography, 1999 Aquatic Sciences Meeting, Abstracts Book, p. 170.

Stumm, W., and Morgan J.J., 1970, Aquatic chemistry-An introduction emphasizing chemical equilibria in natural waters: New York, Wiley-Interscience, 583 p.
Thomann, R.V., and Mueller, J.A., 1987, Principles of surface water quality modeling and control: New York, Harper Collins, $644 \mathrm{p}$.

Todd, D.K., 1980, Groundwater hydrology (2d ed.): New York, John Wiley and Sons, Inc., 535 p.

Tipping, E., 1984, Temperature dependence of MN(II) oxidation in lakewaters-A test of biological involvement: Geochimica et Cosmochimica Acta, v. 48, p. 1353-1356.

U.S. Environmental Protection Agency, 1998, Clean water action plan-Restoring and protecting America's waters: U.S. Environmental Protection Agency, EPA840-R-98-001, 89 p.

U.S. Geological Survey, 1992, Recommendation for use of retransformation methods in regression models used to estimate sediment loads ("the bias correction problem"): U.S. Geological Survey, Office of Surface Water Technical Memorandum No. 93.08, 13 p.

U.S. Geological Survey, 1999, The quality of our Nation's waters-Nutrients and pesticides: U.S. Geological Survey Circular 1225, $82 \mathrm{p}$.

Wetzel, R.G., 1993, Limnology (2d ed.): Philadelphia, W.B. Saunders Co., 743 p.

Wetzel, R.G., and Likens, G.E., 1991, Limnological analysis (2d ed.): Philadelphia, W.B. Saunders Co., 391 p.

Wilde, F.D., Radtke, D.B., Gibs, Jacob, and Iwatsubo, R.T., 1999, Collection of water samples, National field manual for the collection of water-quality data: U.S. Geological Survey Techniques of Water-Resources Investigations, book 9, chap. A4, 103 p.

Winter, T.C., 1981, Uncertainties in estimating the water balance of lakes: Water Resources Bulletin, v. 17, p. 82-115.

\section{GLOSSARY}

Algal bloom-The rapid proliferation of passively floating, simple plant life in and on a body of water.

Anoxic-The absence of oxygen; anaerobic.

Atmospheric deposition-The transfer of substances from the atmosphere to the surface of the Earth or to objects on its surface. Transfer can be either by wet-deposition processes (rain, snow, dew, fog, frost, hail) or by dry deposition (gases, aerosols, fine to coarse particles) in the absence of water.

Bed sediment - The material that temporarily is stationary in the bottom of a stream or other water body.

Colony-forming units (CFU)-Unit of bacterial population size referring to the colonies that appear on a nutrient- 
agar plate following inoculation of the plate with a sample of water. Each colony may arise from a single bacterial cell or from a small cluster of cells; hence, the colony is reported as a CFU and the bacterial population density is reported as the number of CFUs per unit volume (usually 100 milliliters) of water.

Contamination-Change of water quality by the addition of constituents as a result of human activity or natural processes.

Constituent-A compound such as a chemical species or biological population whose magnitude in water, sediment, biota, or other matrix is determined by an analytical method.

Correlation coefficient-A statistic that can be used to measure the strength of a relation between two variables.

Discharge (hydraulics) - Rate of flow, especially fluid flow; a volume of liquid passing a point per unit of time, commonly expressed in cubic feet per second, million gallons per day, or liters per second.

Dissolved oxygen (DO)-Oxygen dissolved in water; one of the most important indicators of the condition of a water body. Dissolved oxygen is necessary for the life of fish and most other aquatic organisms.

Drainage basin - Land area drained by a river or stream; watershed.

Epilimnion-Warm, oxygen-rich, upper layer of water in a lake or other body of water, usually seasonal. See also Metalimnion, Hypolimnion

Eutrophic-Term applied to a body of water with a high degree of nutrient enrichment and high productivity.

Eutrophication-Process by which water becomes enriched with plant nutrients, most commonly phosphorus and nitrogen.

Fecal coliform bacteria-Group of several types of bacteria that are found in the alimentary tract of warm-blooded animals. The bacteria commonly are used as an indicator of animal and fecal contamination of water.

Ground water-In the broadest sense, all subsurface water, as distinct from surface water; as more commonly used, that part of the subsurface water in the saturated zone. See also Surface water.

Hypolimnion - Cold, oxygen-poor, deep layer of water in a lake or other water body. See also Epilimnion, Metalimnion

Hypoxic-The near absence of oxygen.

Kettle-hole lake-Glacially-formed lake with no surfacewater inflows or outflows.
Limnology-Scientific discipline dealing with the physics, chemistry, and biology of inland waters such as lakes, ponds, reservoirs, streams, and wetlands.

Load-Material that is moved or carried by streams, reported as the weight of the material transported during a specific time period, such as kilograms per day or tons per year.

Main stem-The main trunk of a river or stream.

Maximum contaminant level (MCL)-Maximum permissible level of a contaminant in water that is delivered to any user of a public water system, established by a regulatory agency such as the U.S. Environmental Protection Agency. See also Secondary maximum contaminant level.

Mean-The arithmetic average obtained by dividing the sum of a set of quantities by the number of quantities in the set.

Median-The middle or central value in a distribution of data ranked in order of magnitude. The median also is known as the 50th percentile.

Mesotrophic-Term applied to a body of water with intermediate nutrient content and intermediate productivity.

Metalimnion-Transition zone between the warm upper layer and the cold deep layer of a lake or other water body, characterized by rapidly decreasing temperature with increasing depth. See also Epilimnion, Hypolimnion.

Minimum reporting limit (MRL)-The lowest measured concentration of a constituent that can be reported reliably using a given analytical method.

Monitoring station-A site on a stream, canal, lake, or reservoir used to observe systematically the chemical quality and discharge or stage of water.

Nutrient-An element or compound essential for animal and plant growth. Common nutrients in fertilizer include nitrogen, phosphorus, and potassium.

Oligotrophic-Term applied to a body of water low in nutrients and in productivity.

pH-The logarithm of the reciprocal of the hydrogen ion concentration of a solution; a measure of the acidity ( $\mathrm{pH}$ less than 7) or alkalinity ( $\mathrm{pH}$ greater than 7$)$ of a solution; a pH of 7 is neutral.

Phytoplankton algae-Free-floating, mostly microscopic aquatic plants.

Phytoplankton chlorophyll $a$-Primary light-trapping pigment in most phytoplankton algae. Concentration can be used as an indirect indicator of the abundance of phytoplankton algae in a lake or other water body. 
Runoff-That part of precipitation that appears in surface streams. It is equivalent to streamflow unaffected by artificial diversions, storage, or other human works in or on the stream channel.

Secondary maximum contaminant level (SMCL)Maximum recommended level of a contaminant in water that is delivered to any user of a public water system. These contaminants affect the esthetic quality of the water such as odor or appearance; therefore, the levels are intended as guidelines. See also Maximum contaminant level.

Specific conductance-A measure of the ability of a sample of water to conduct electricity.

Subbasin-Drainage basin or watershed defined by a specific monitoring station and representing the land area that contributes water to that station.

Surface water-An open body of water, such as a stream or lake. See also Ground water.

Swamp-A forested wetland that has standing water during most or all of the growing season.

Thermal stratification-Seasonal division of a lake or other water body into a warm upper layer and a cold deep layer that is no longer in contact with the atmosphere. In some lakes, thermal stratification can result in a loss of oxygen in the deep layer and subsequent chemical stratification.
Trihalomethane formation potential (THMFP)Tendency of naturally occurring organic compounds in a water supply to form toxic trihalomethanes during water treatment.

Trophic state-The extent to which a body of water is enriched with plant nutrients. See also Eutrophic, Mesotrophic, Oligotrophic.

Trophic state index (TSI)-A numerical index indicating the degree of nutrient enrichment of a body of water.

Turbidity - The opaqueness or reduced clarity of a fluid due to the presence of suspended matter.

Water year-The continuous 12-month period, October 1 through September 30, in U.S. Geological Survey reports dealing with the surface-water supply. The water year is designated by the calendar year in which it ends and which includes 9 of the 12 months. Thus, the year ending September 30,1998, is referred to as the "1998" water year.

Wetlands-Lands that are inundated or saturated by surface or ground water at a frequency and duration sufficient to support, and that under normal circumstances do support, a prevalence of vegetation typically adapted for life in saturated soil conditions.

Yield-The weight of material transported during any given time divided by unit drainage area, such as kilograms per day per square kilometer or tons per year per square mile. 
FIGURES 3-7 


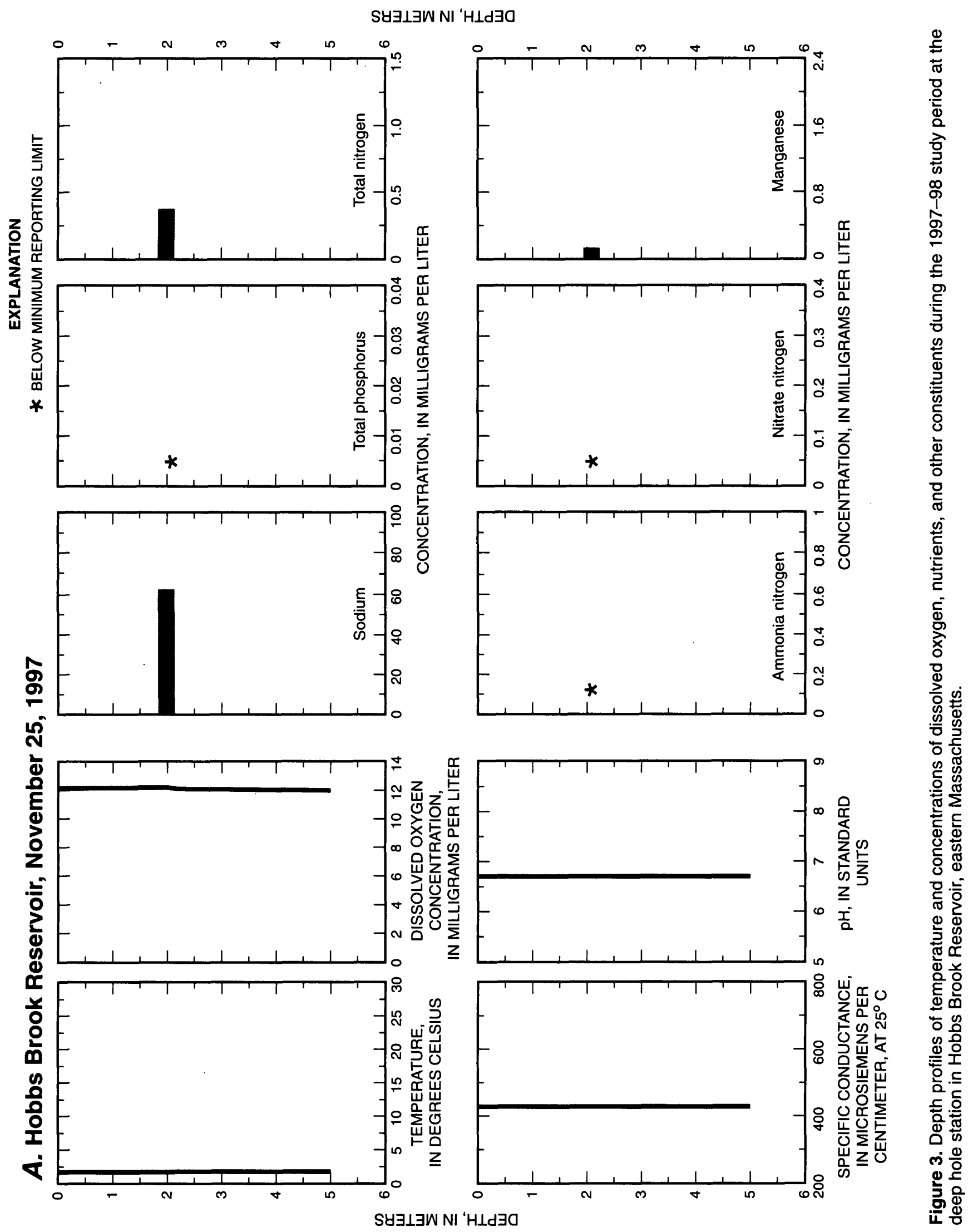




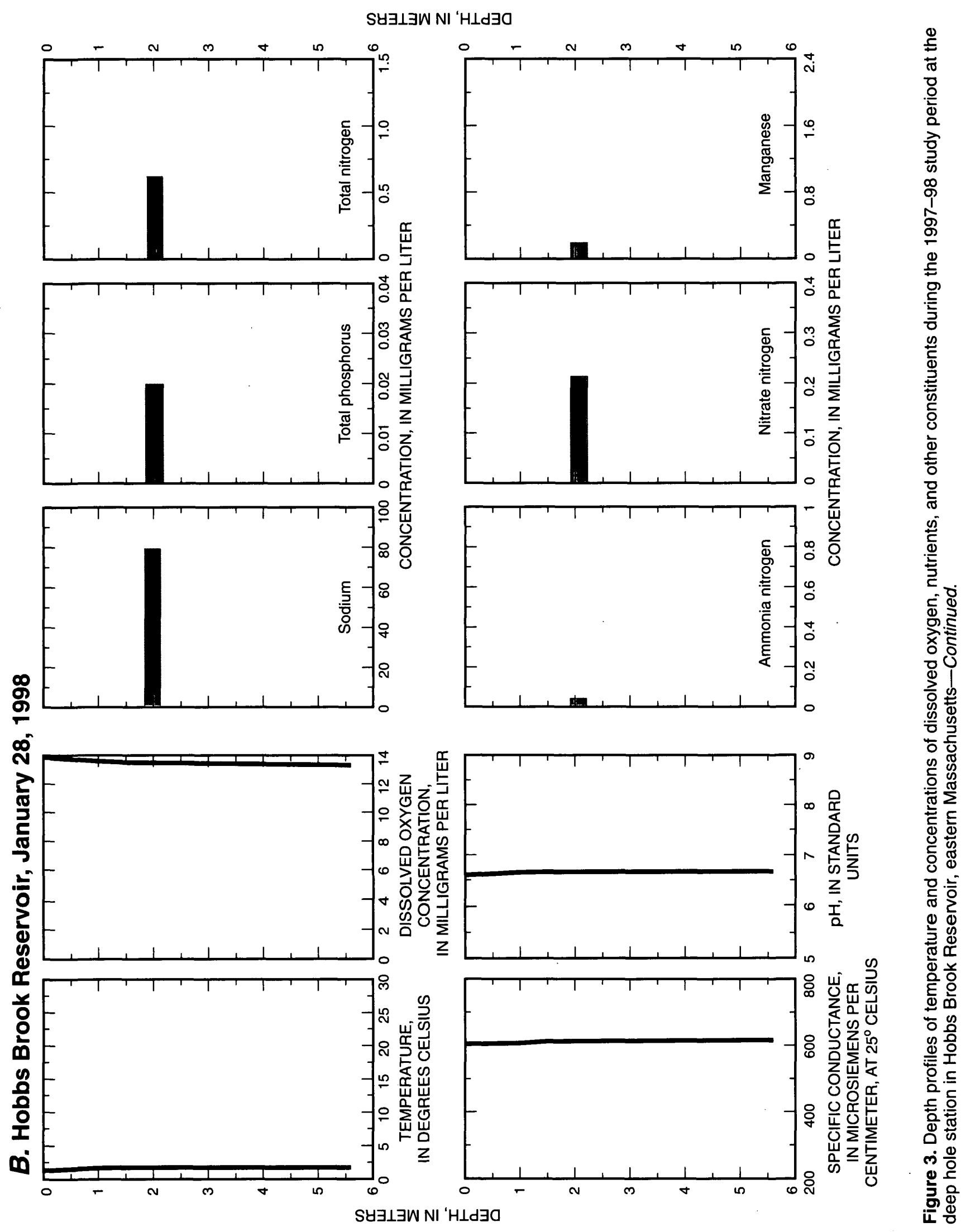




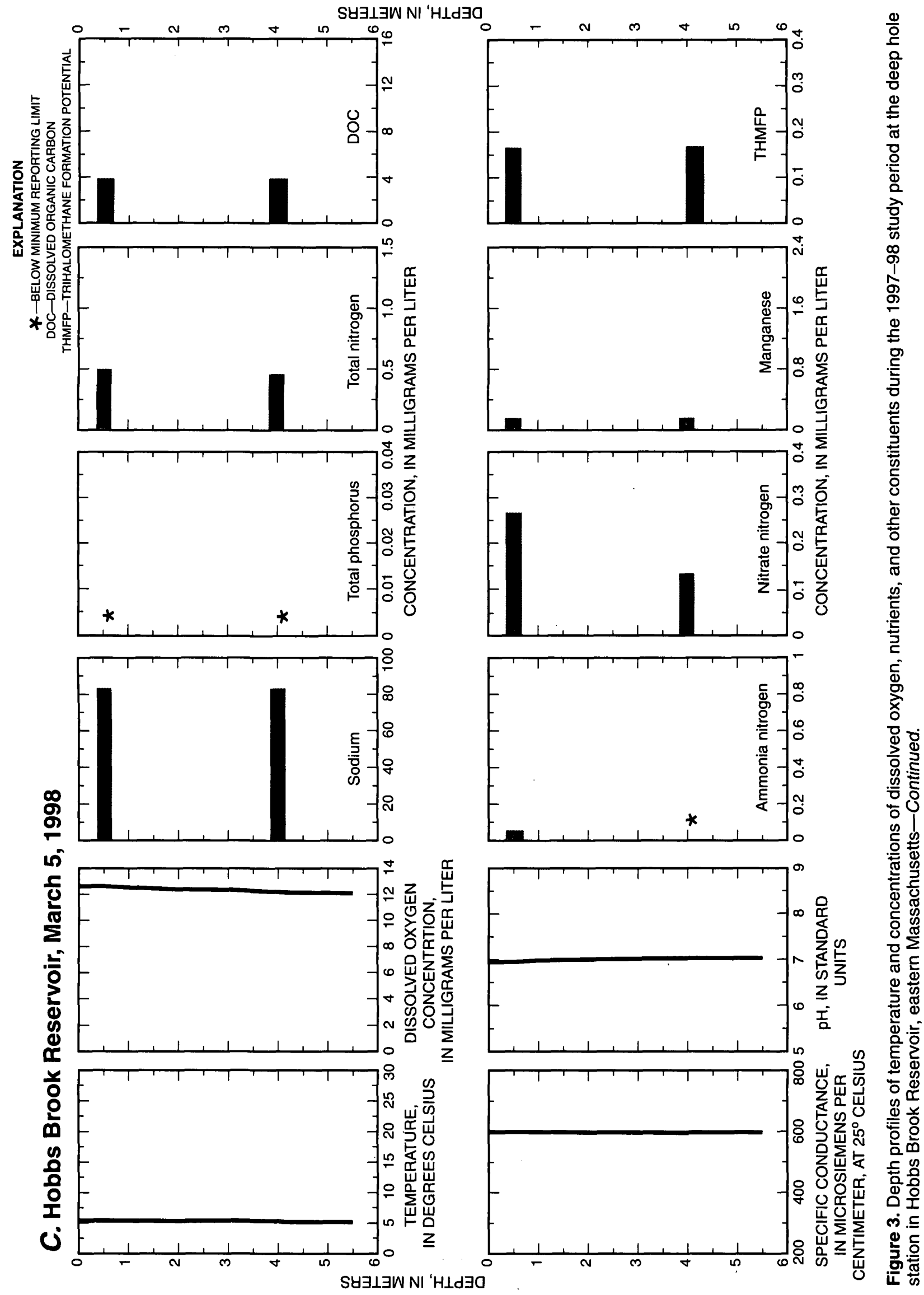

Figure 355 


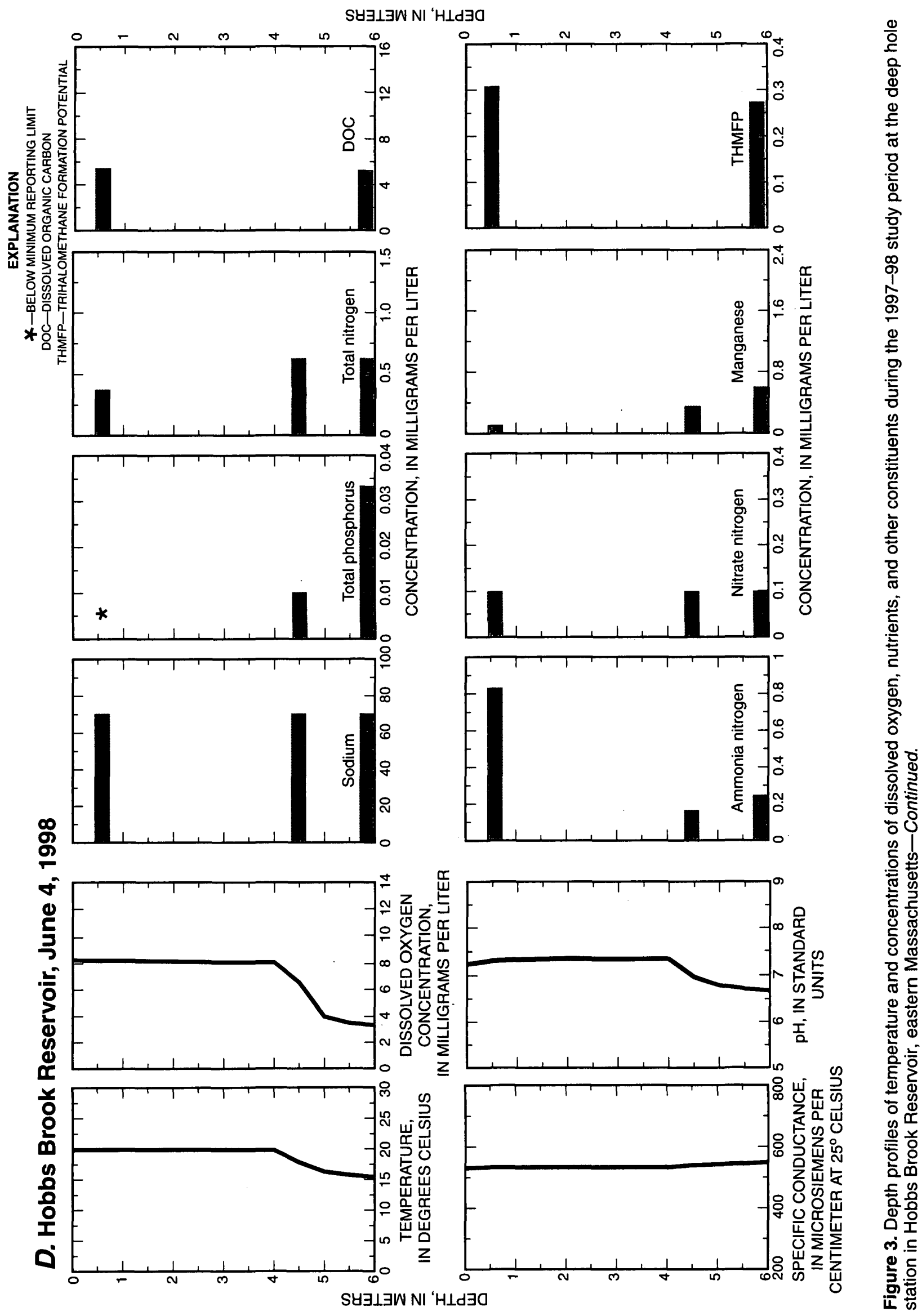




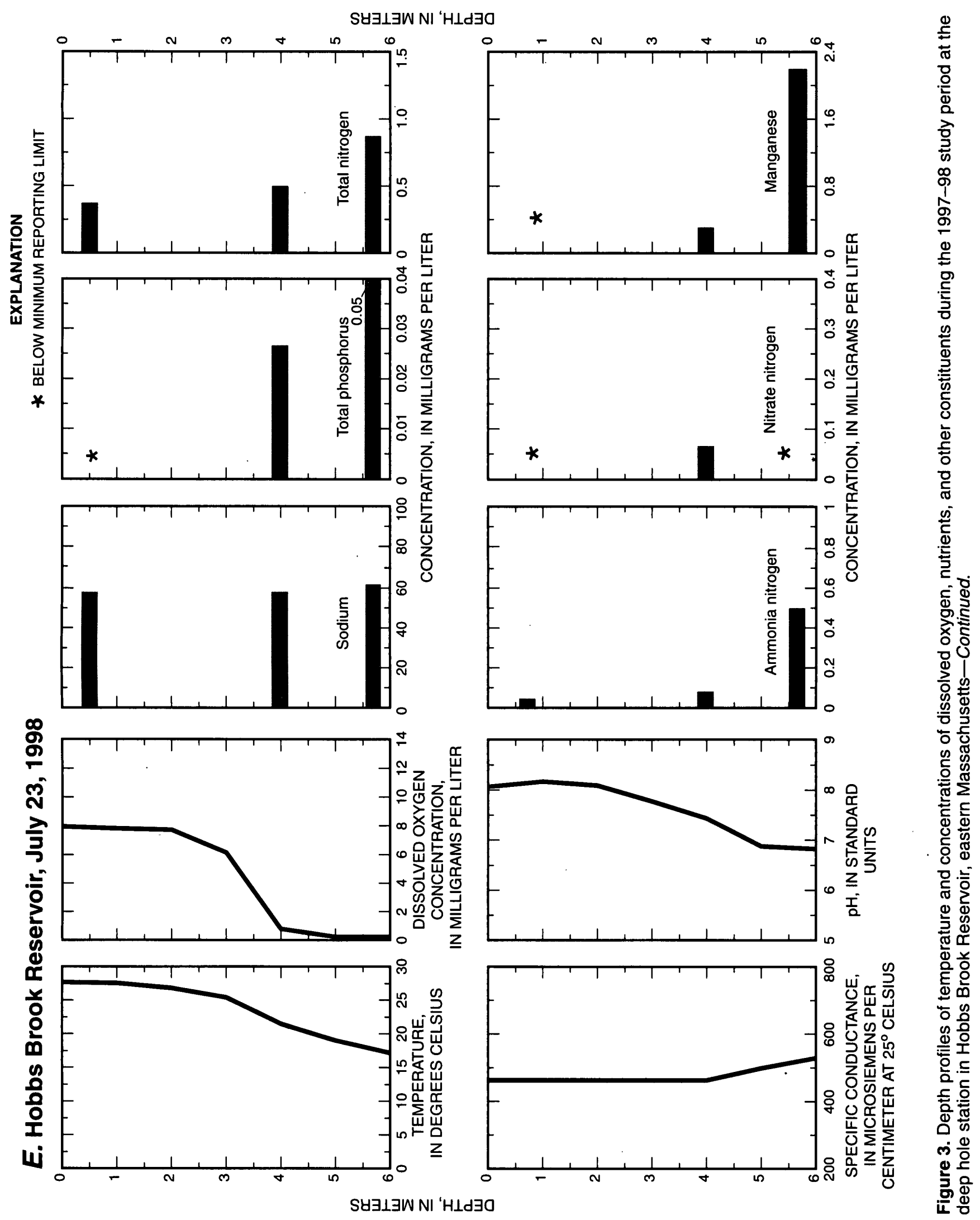




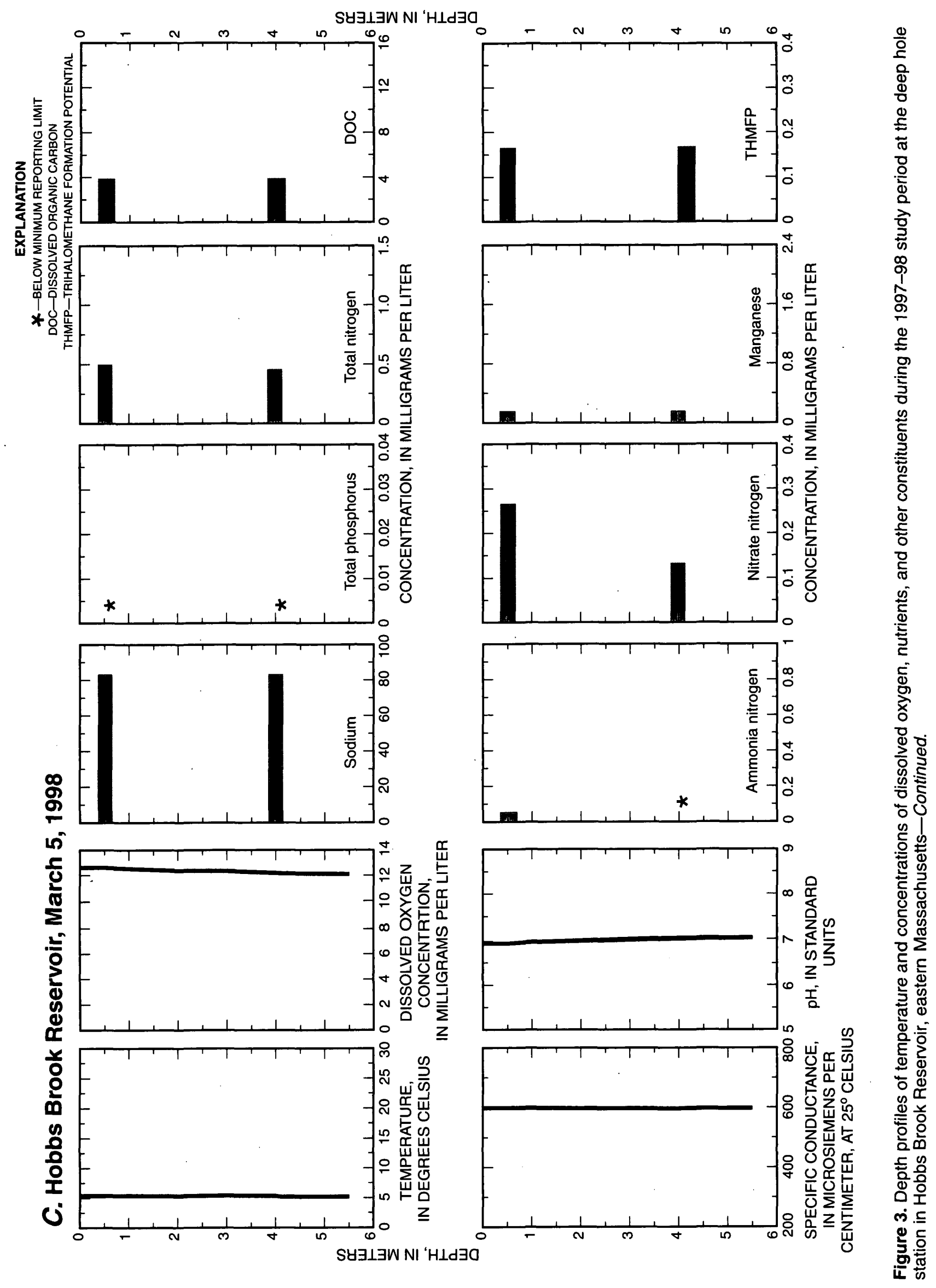




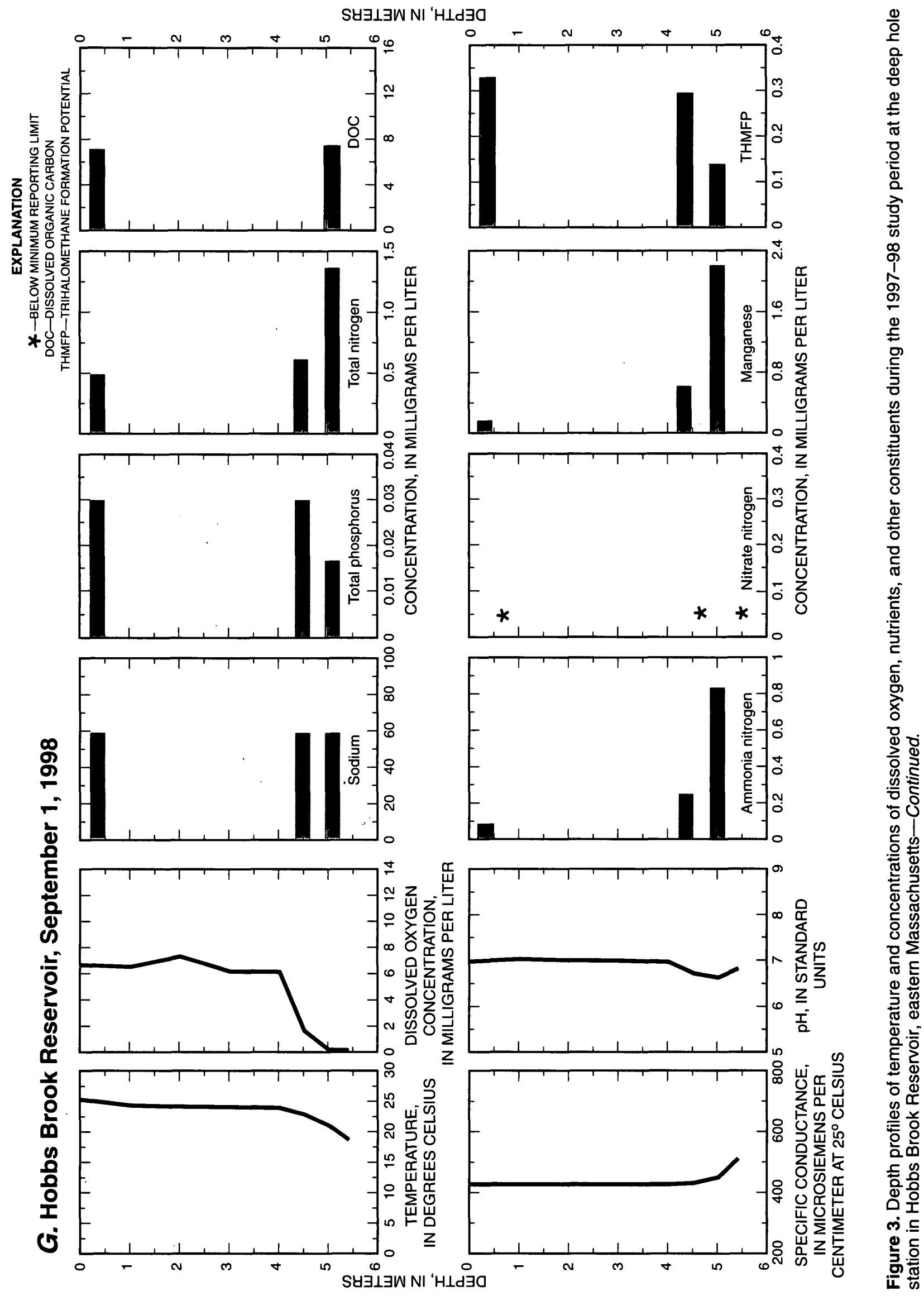




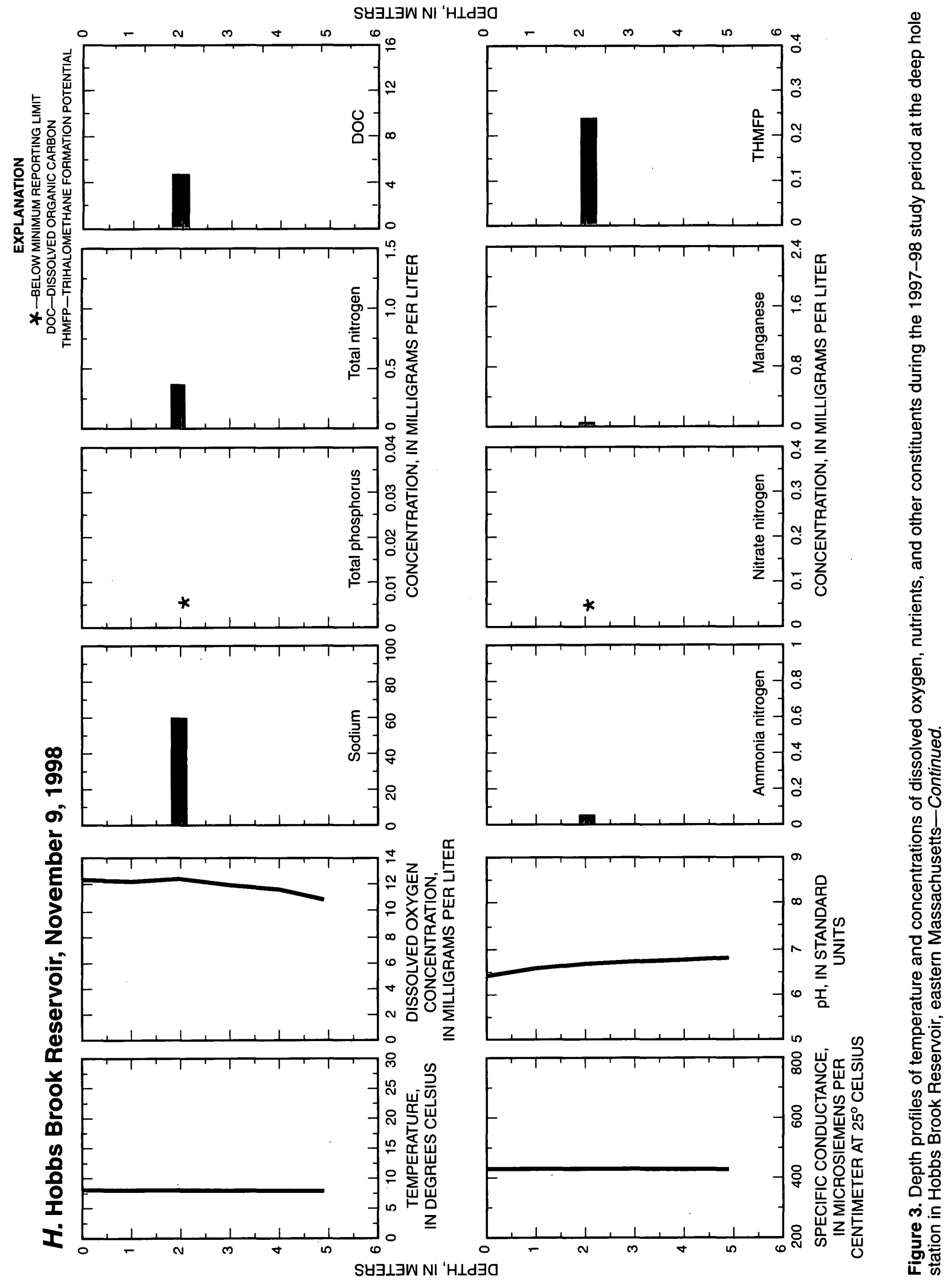




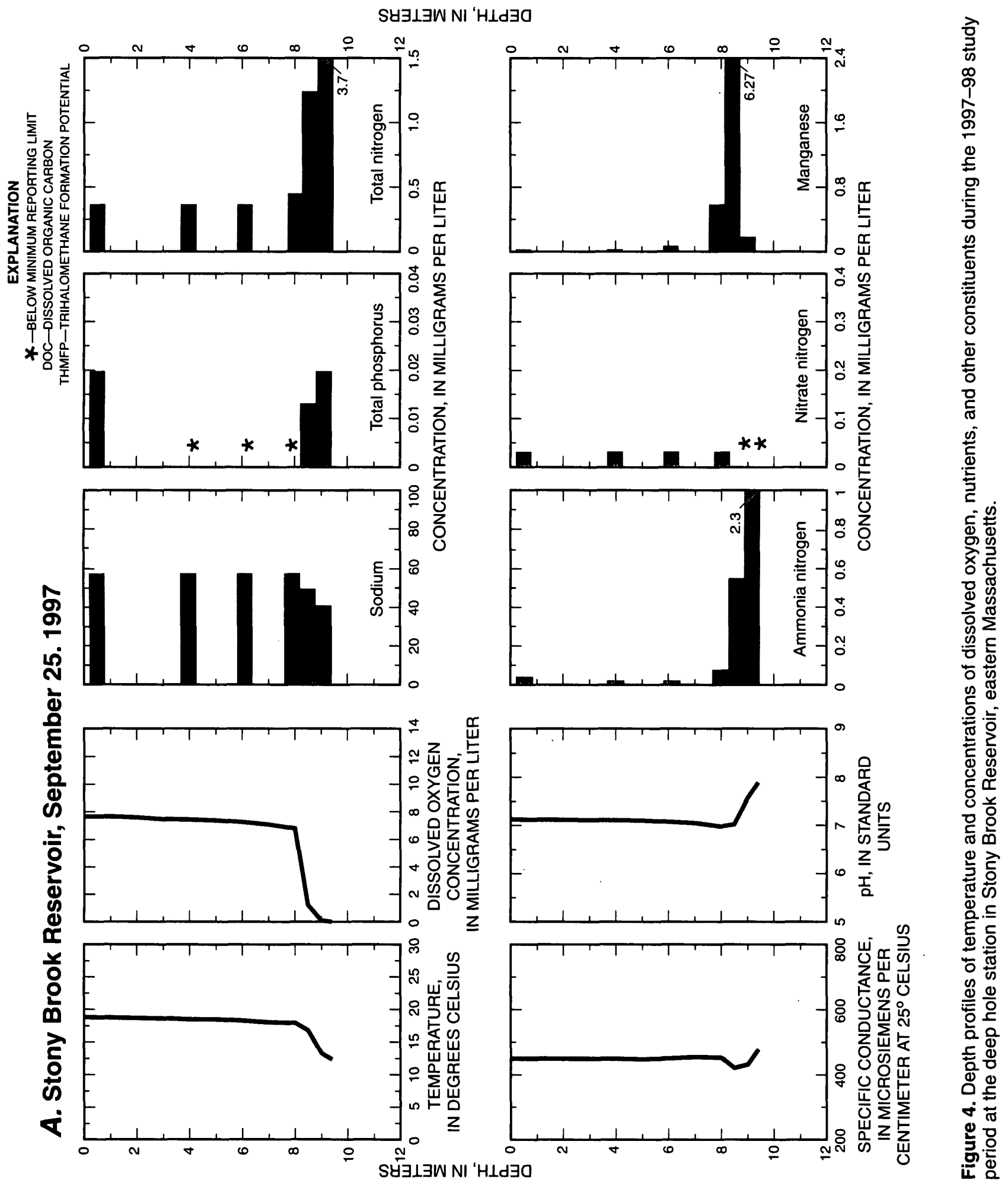




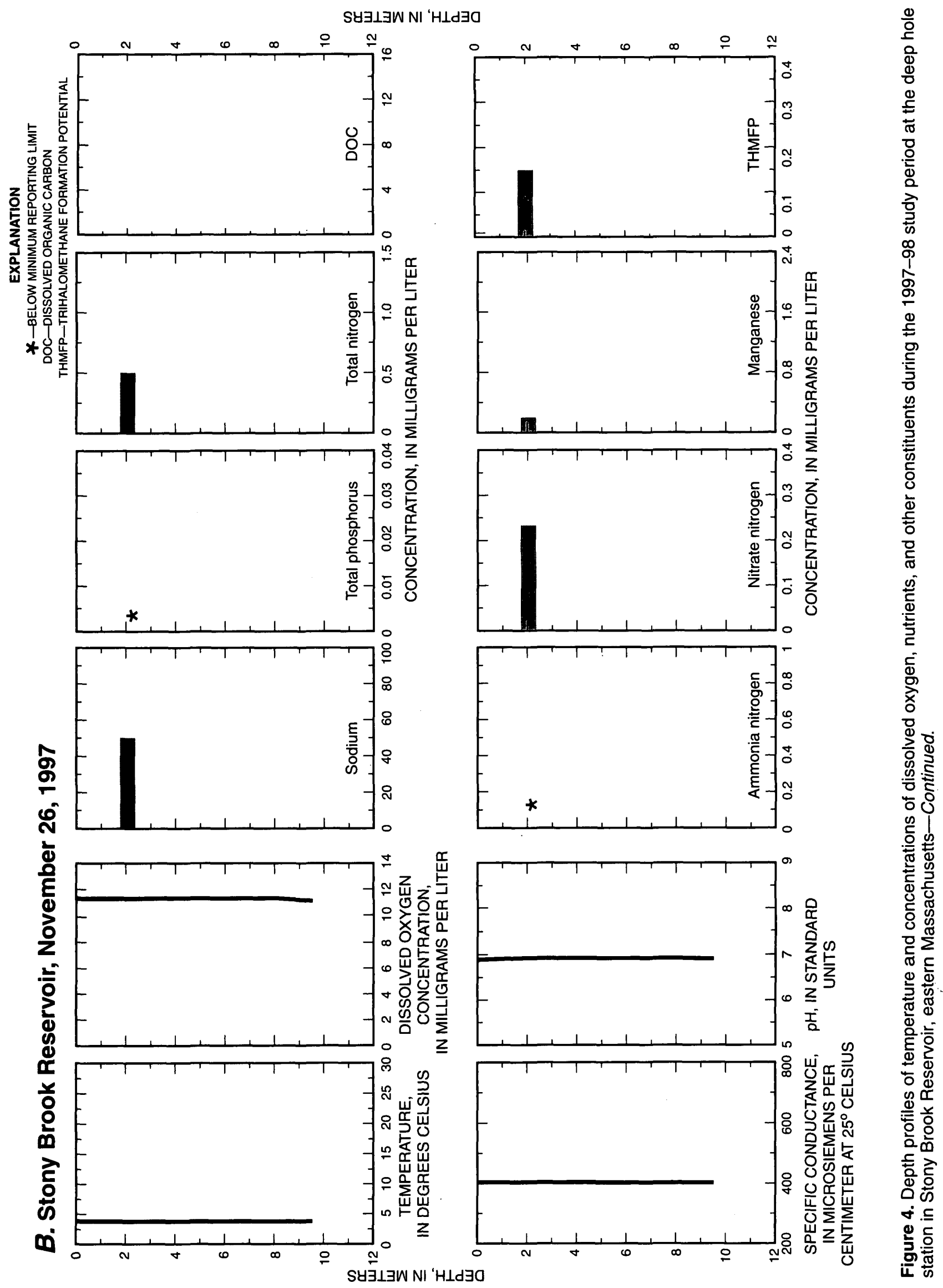




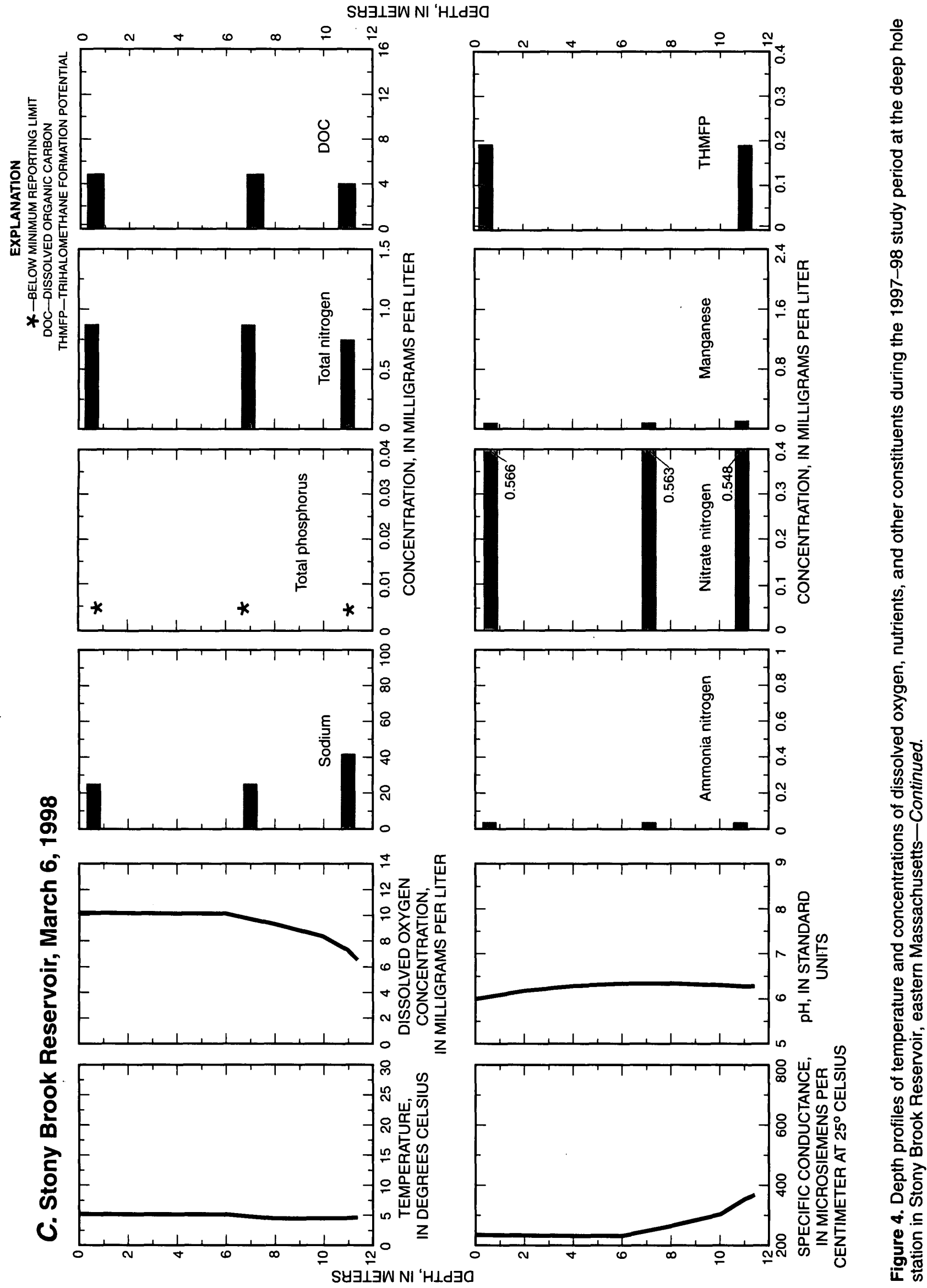

Figure 463 


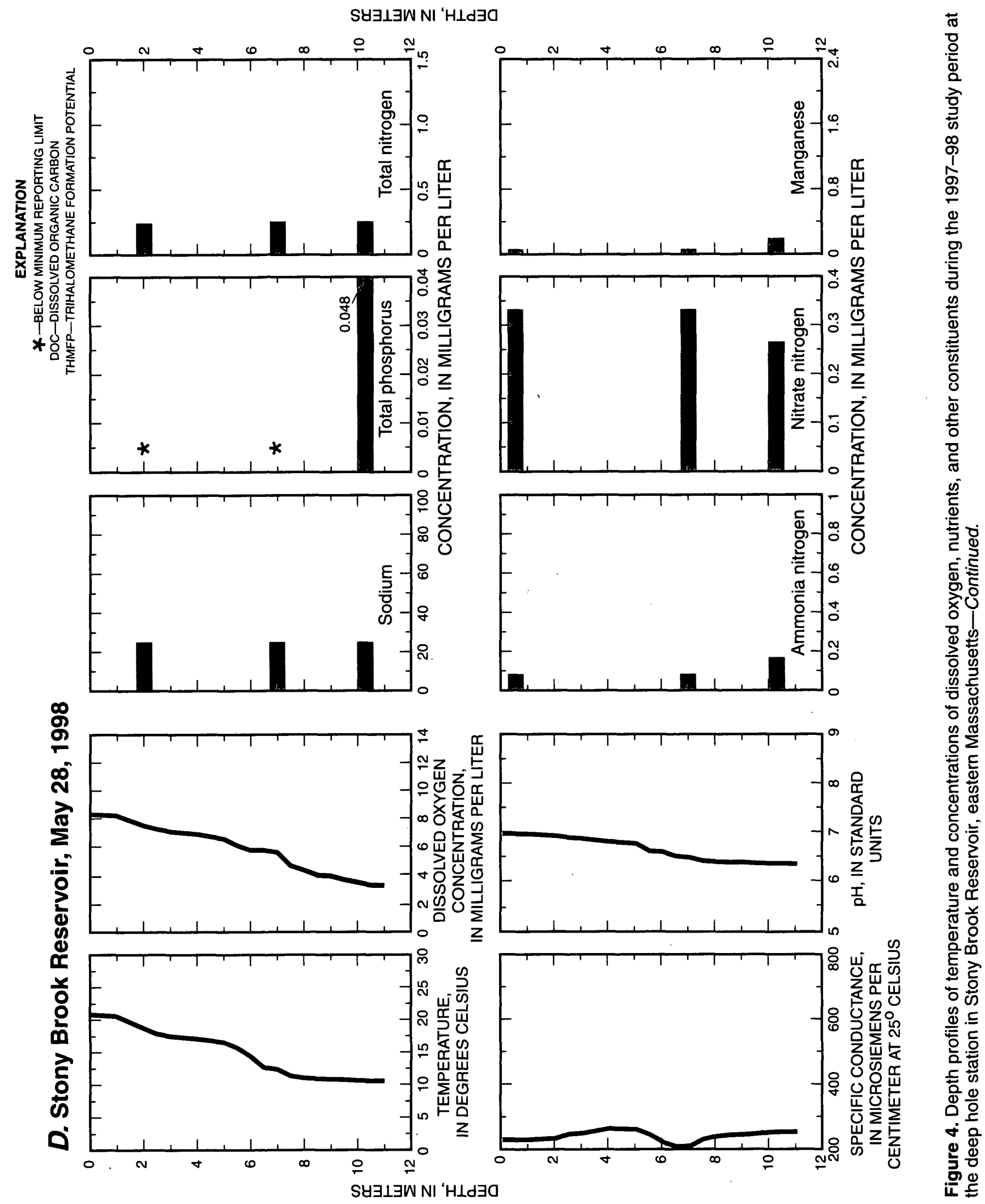




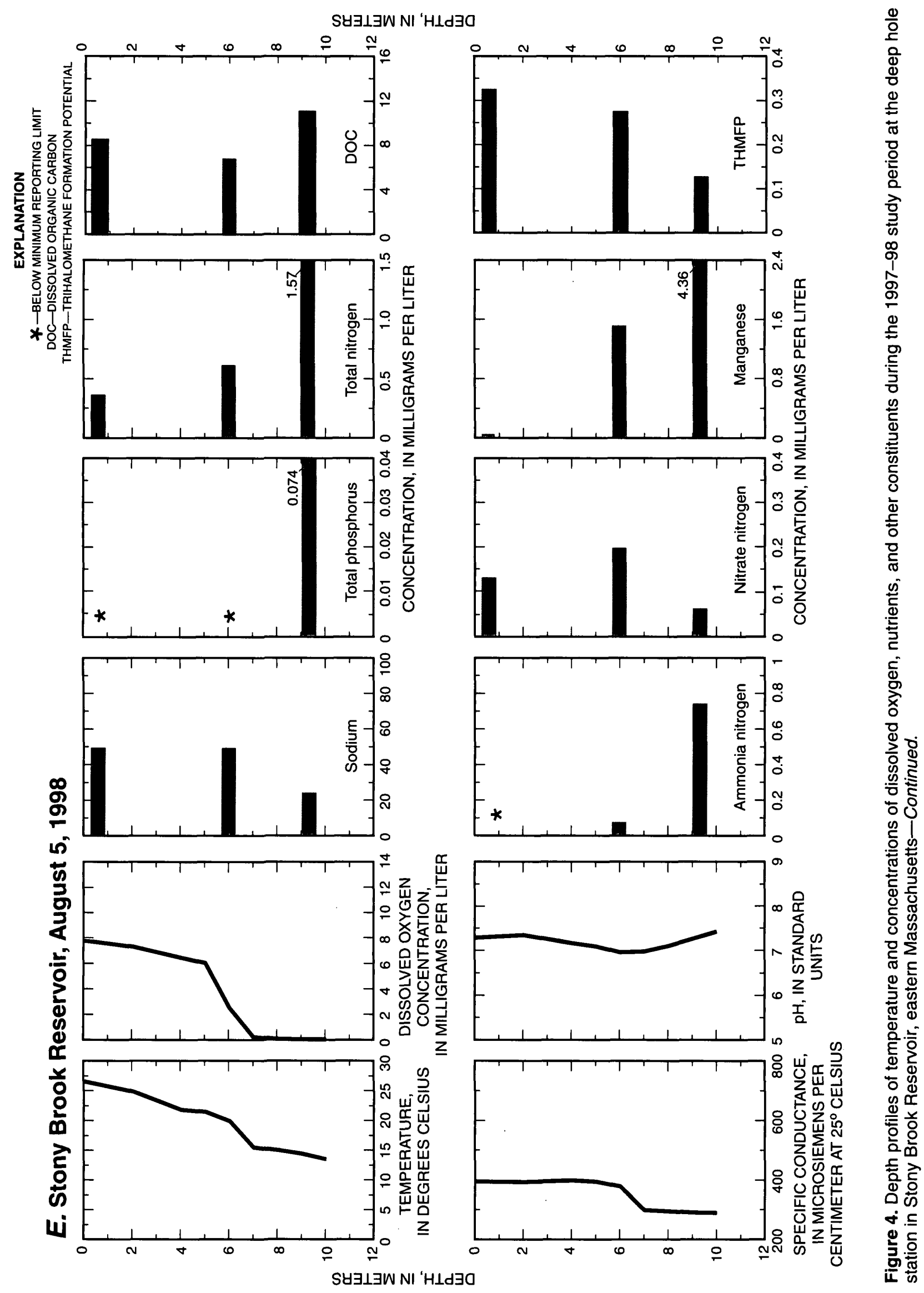

Figure $4 \quad 65$ 


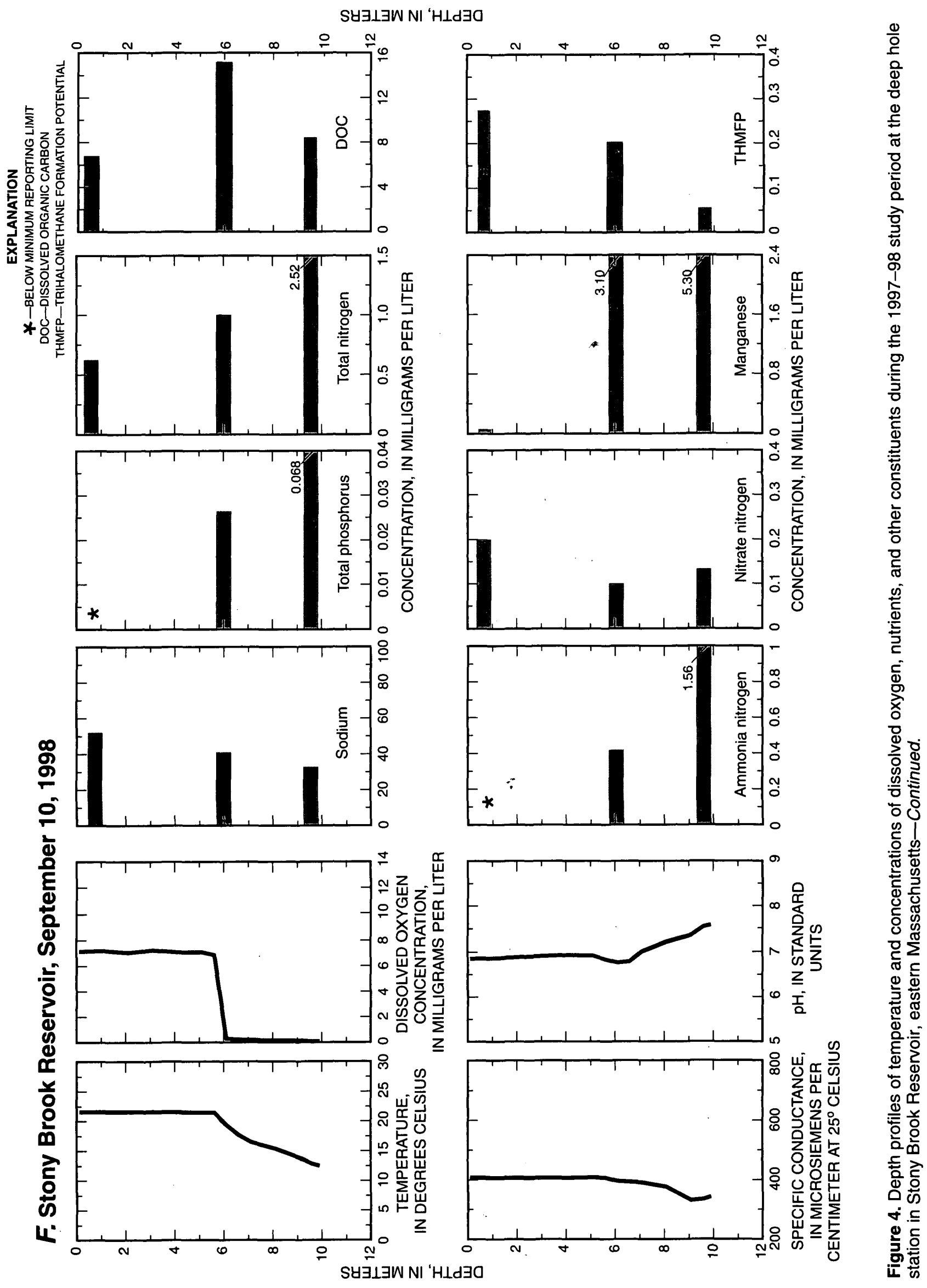




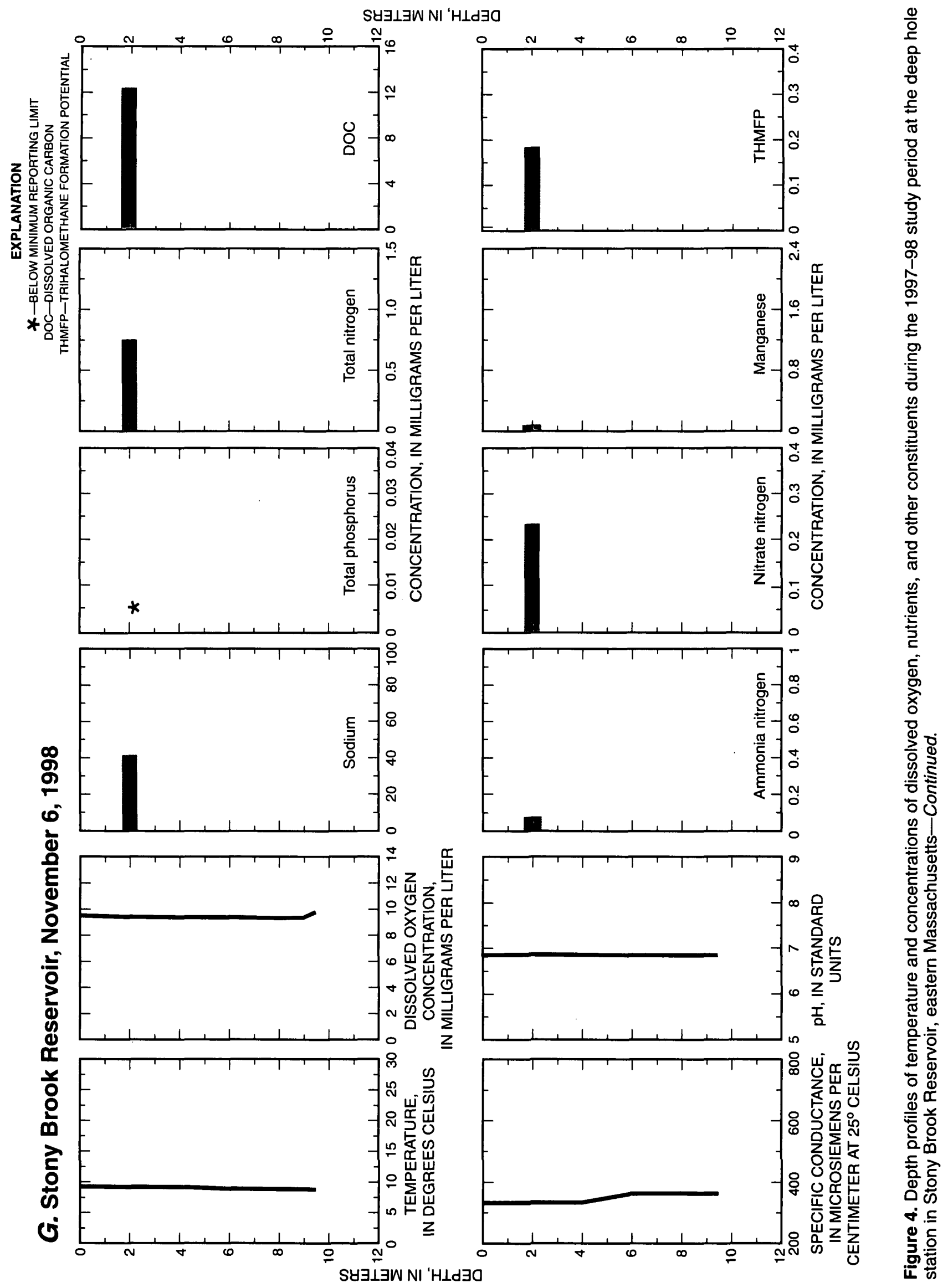

Figure $4 \quad 67$ 


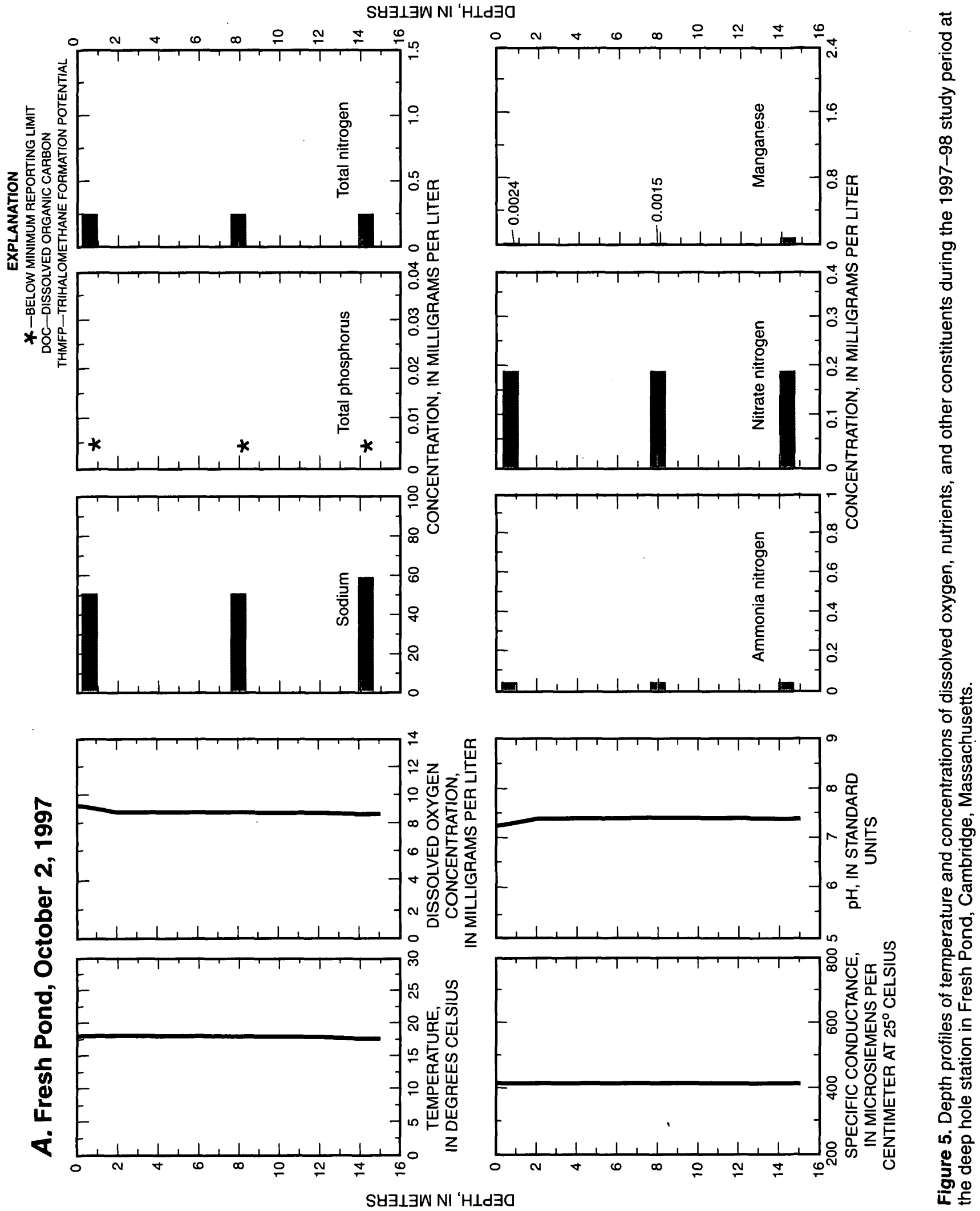




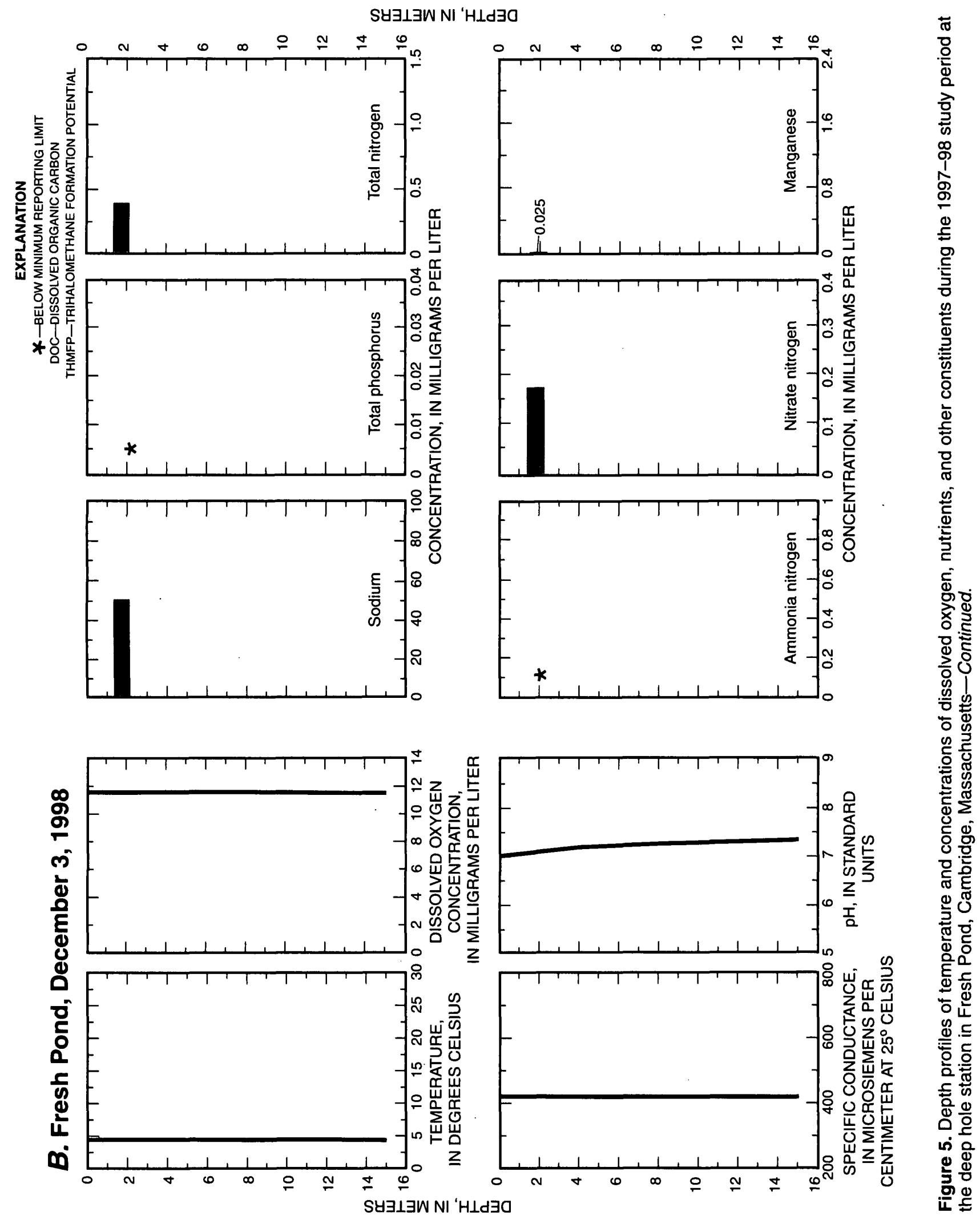




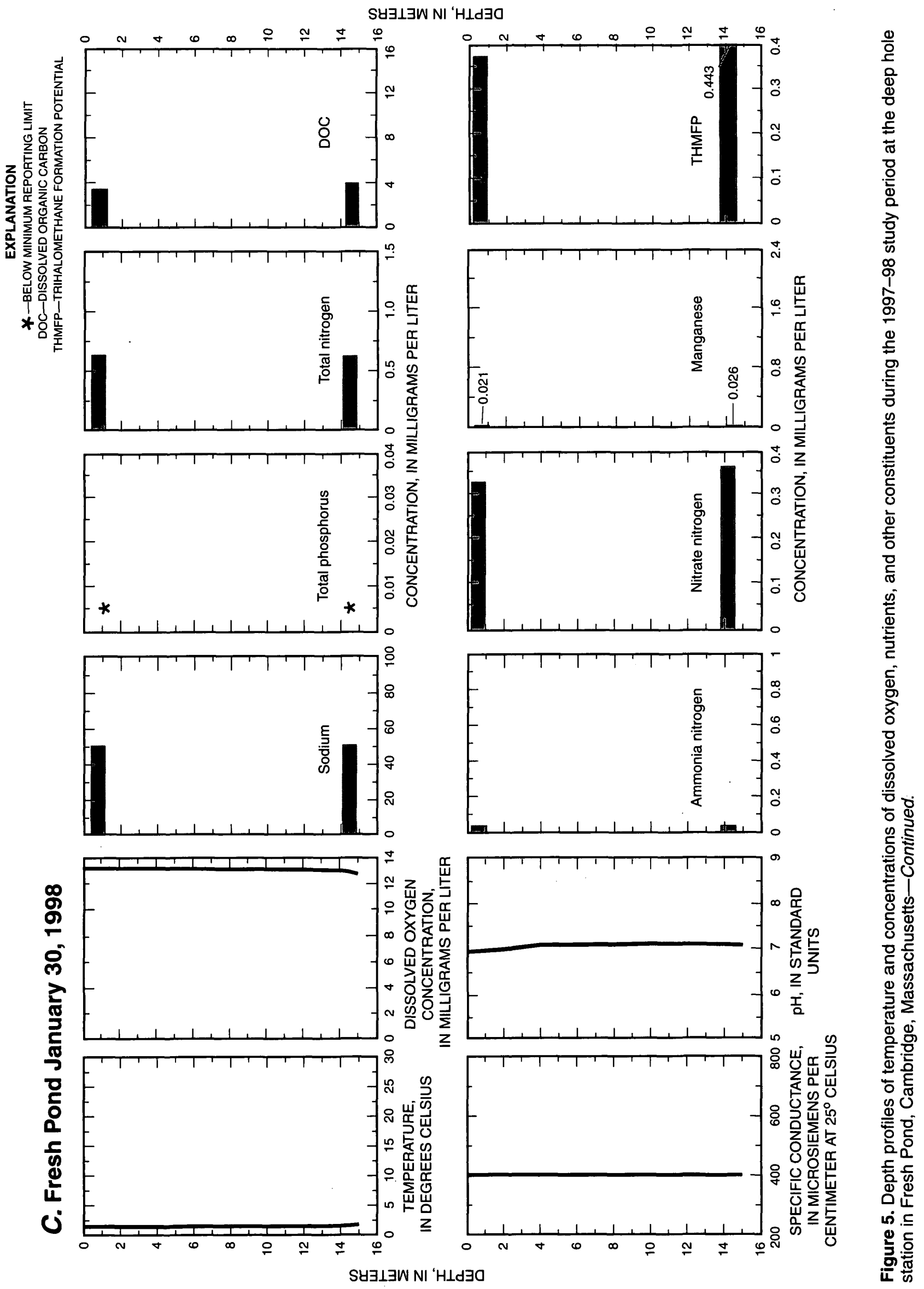




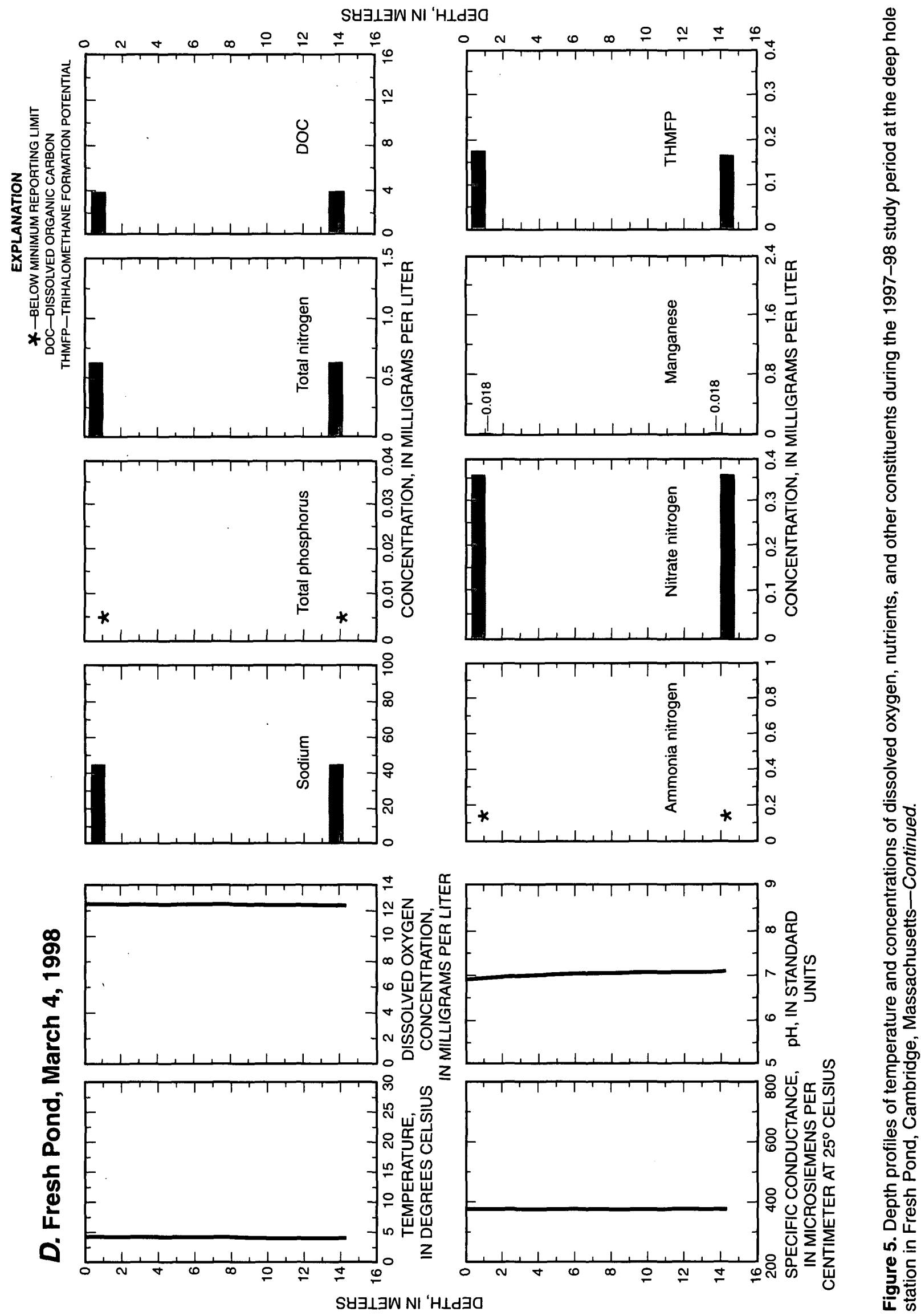

Figure $5 \quad 71$ 


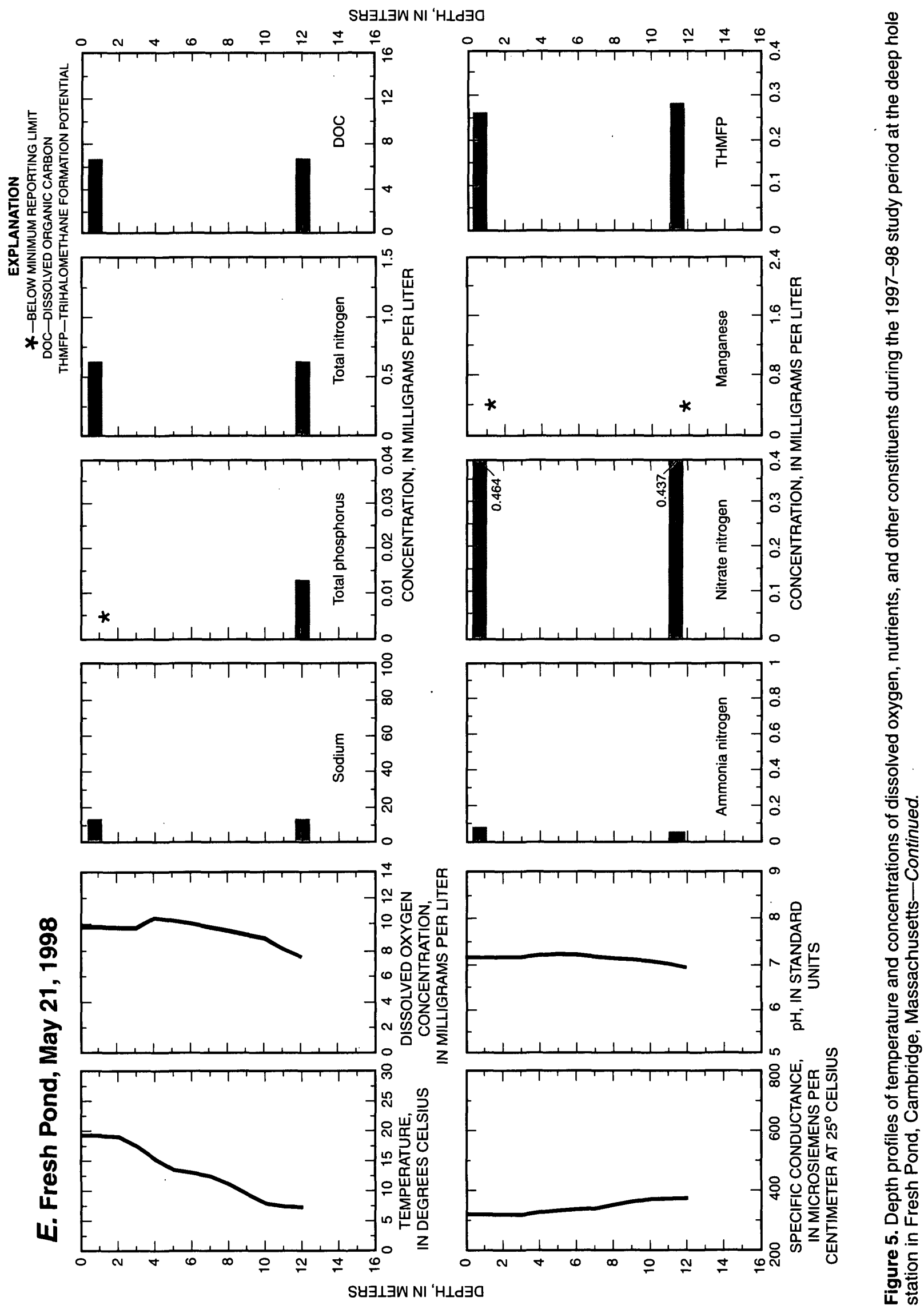




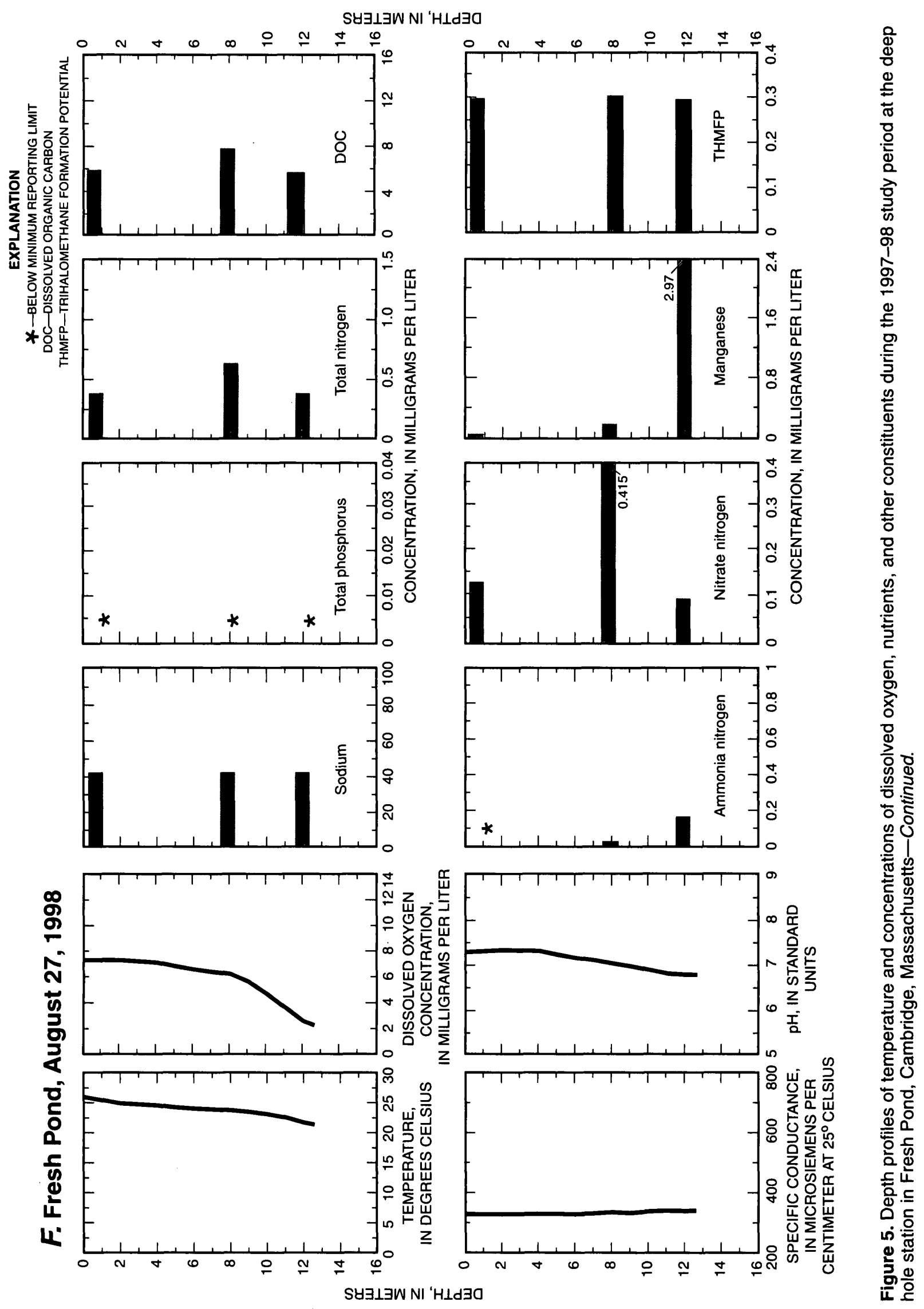




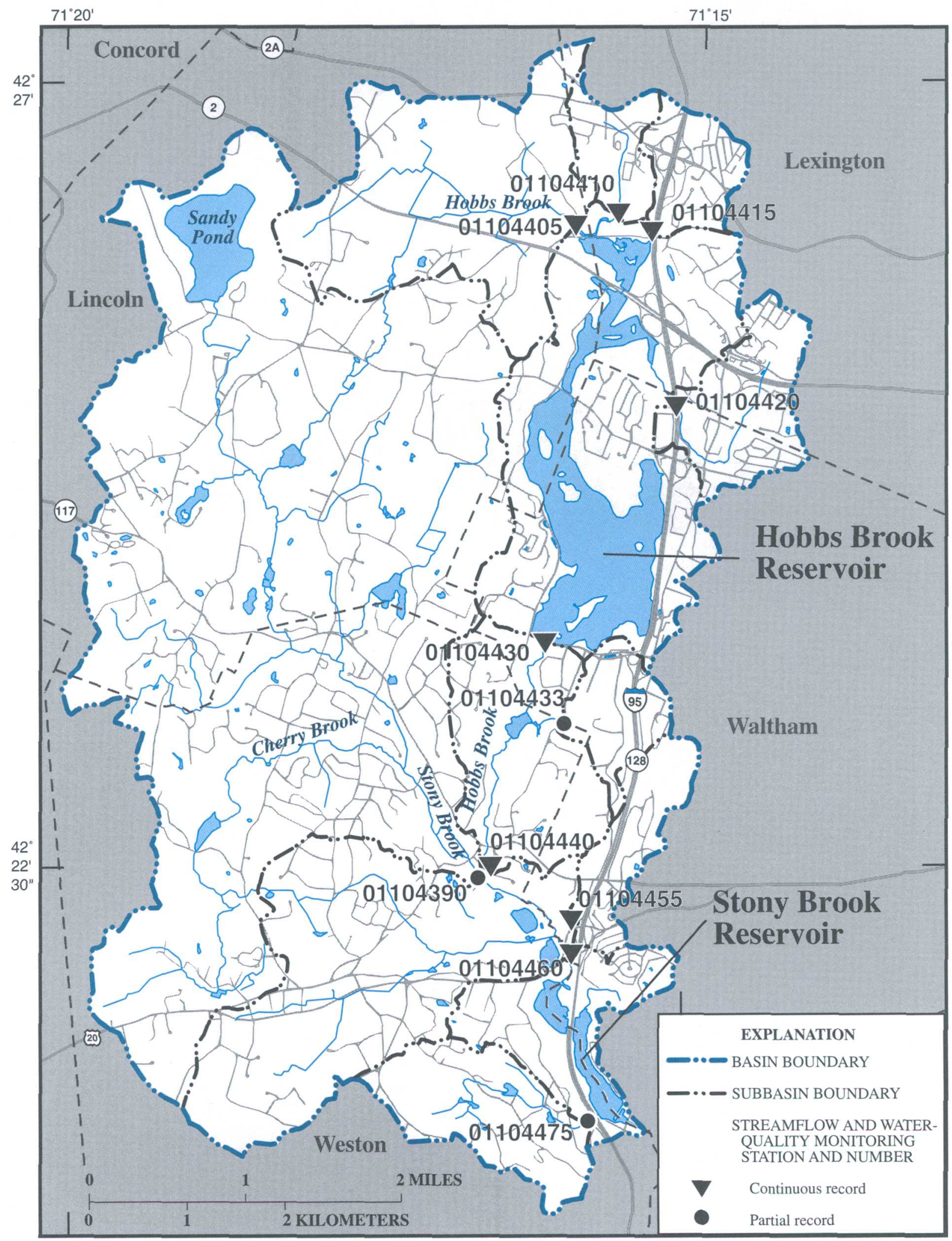

Base from U.S. Geological Survey NMD, MassGIS, Cambridge Water Department, Harvard Design and Mapping, and Boston Edison.

Figure 6. Hydrography, subbasin boundaries, and streamflow and water-quality monitoring stations in the Cambridge, Massachusetts, drinking-water source area. 
A.

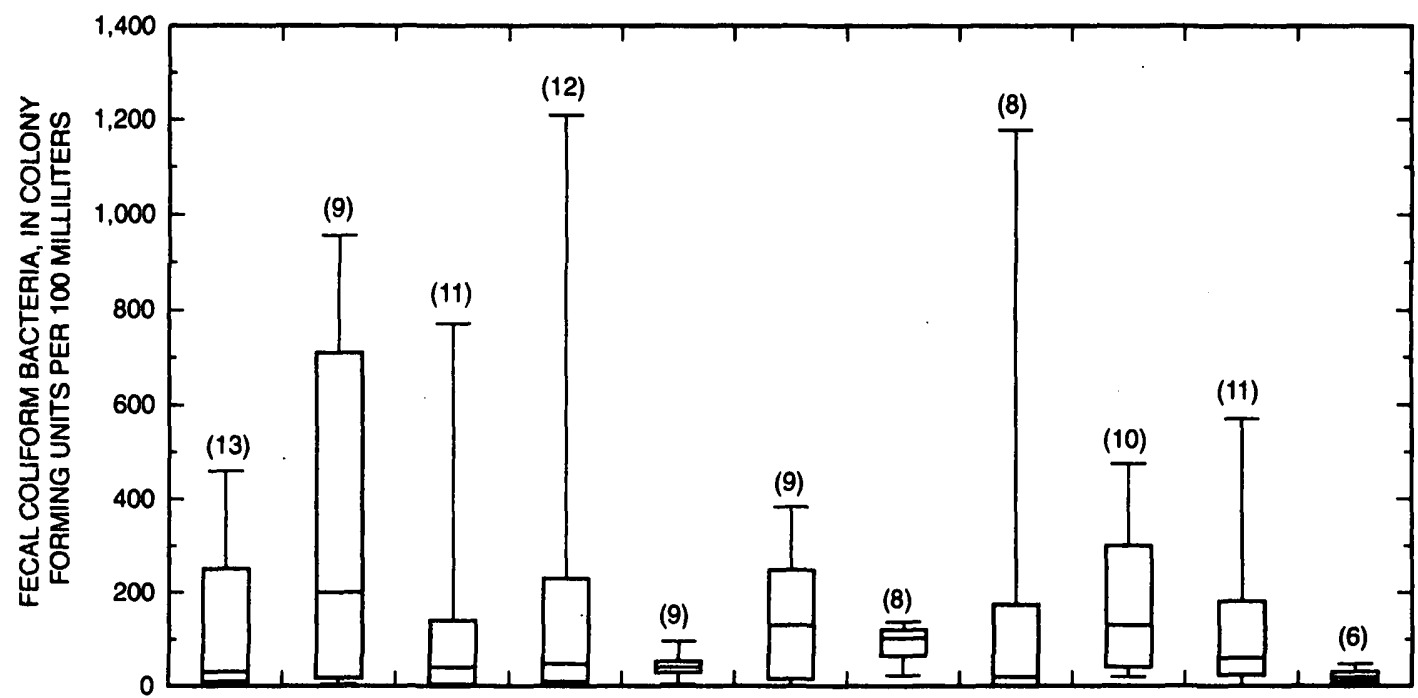

EXPLANATION

(11) NUMBER OF MEASUREMENTS

- 90th percentlle

7 - 75th percentile

- Median

_ 25th percentile

- 10th percentile

B.

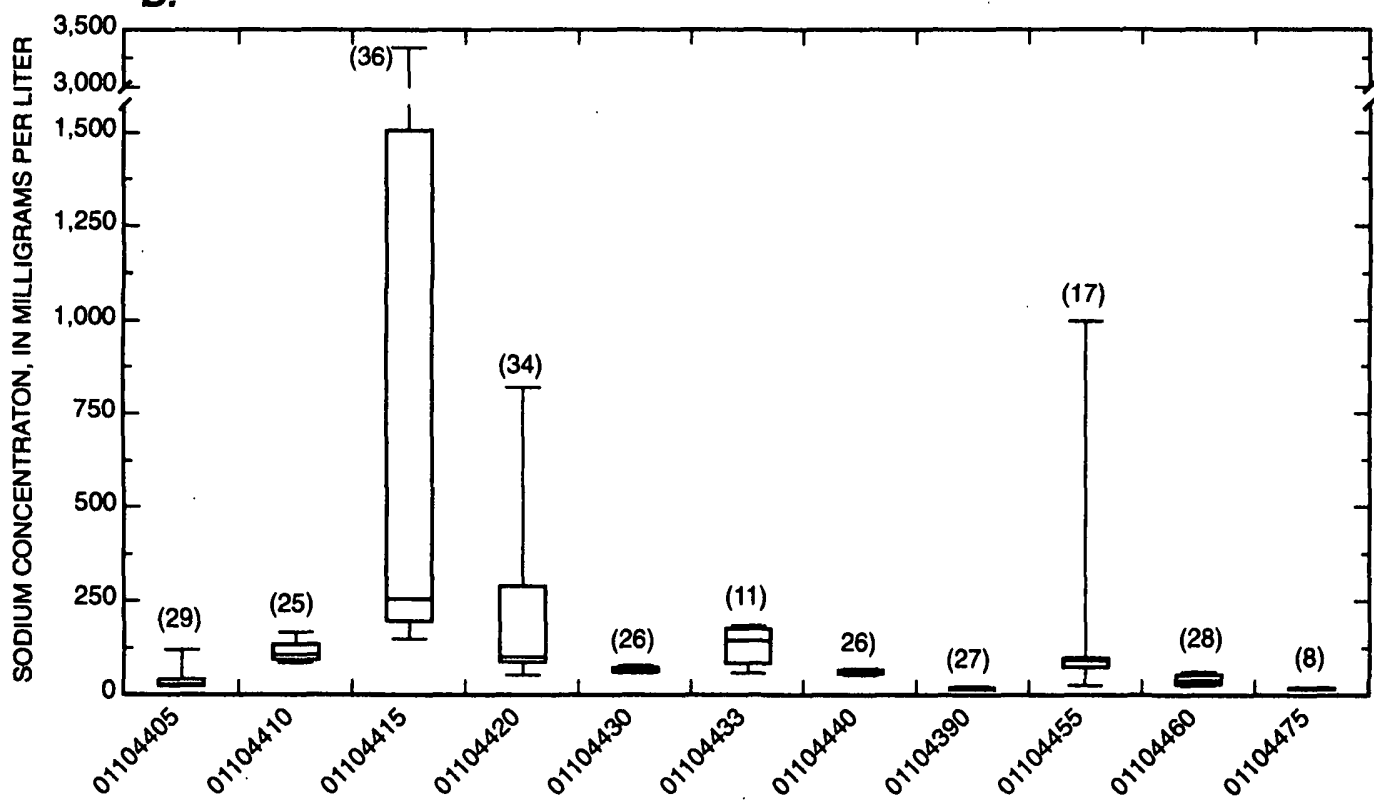

U.S. GEOLOGICAL SURVEY STATION NUMBER

Figure 7. Concentrations of selected chemical constituents detected at eleven monitoring stations in subbasins that contribute water to Hobbs Brook and Stony Brook Reservoirs, eastern Massachusetts, September 1997-November 1998. 
C.

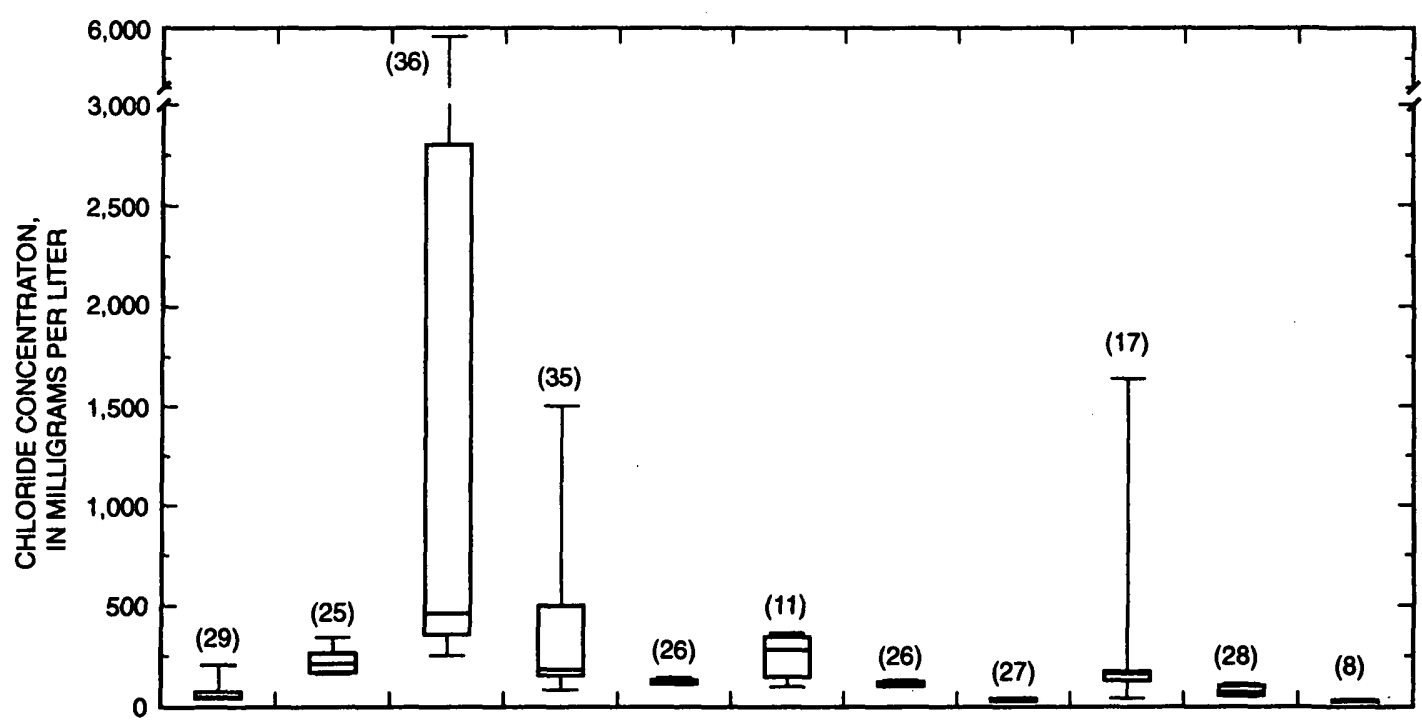

EXPLANATION

(8) NUMBER OF MEASUREMENTS

- soth percentile

75th percentile

- Median

- 25th percentile

- 10th percentile

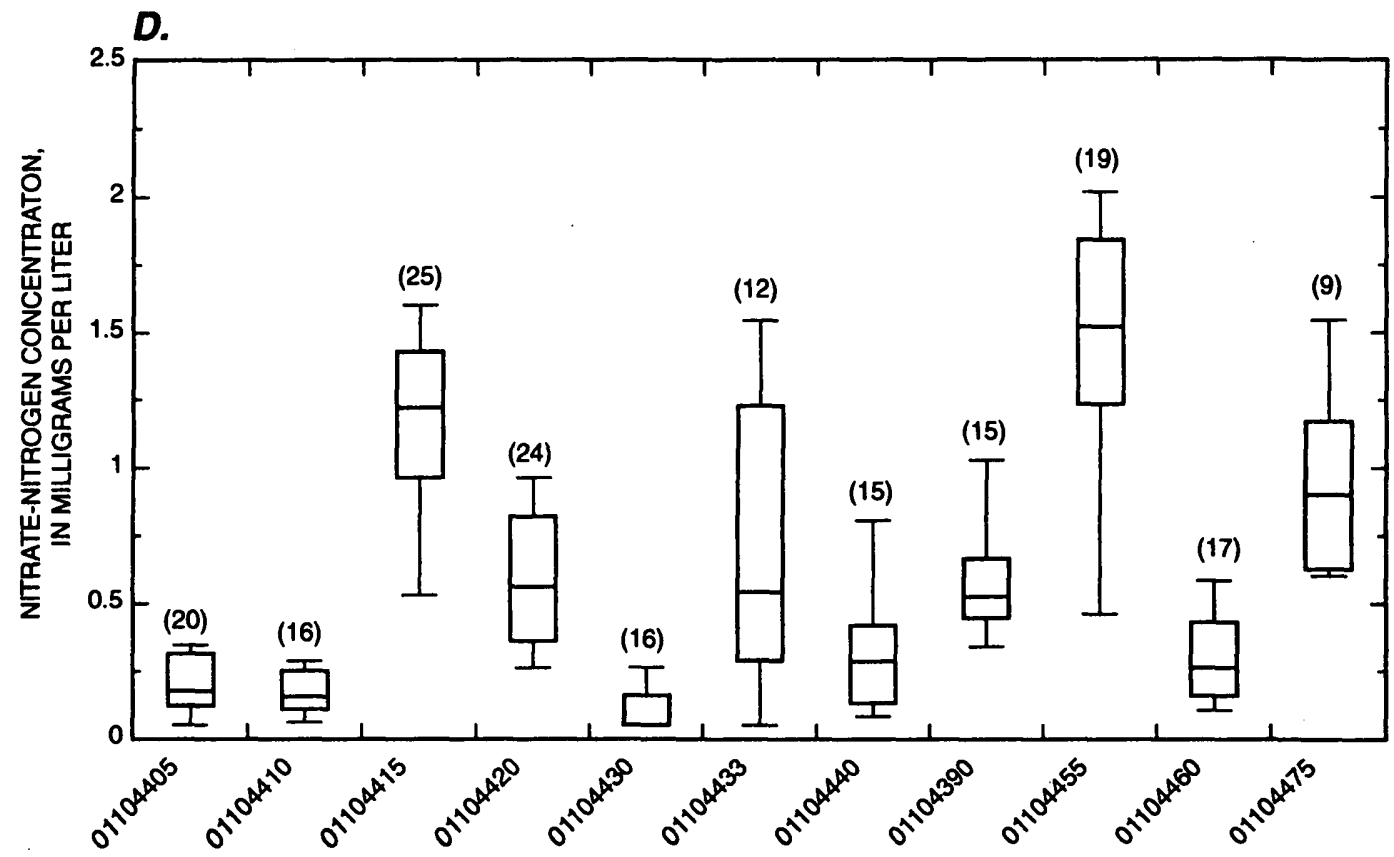

U.S. GEOLOGICAL SURVEY STATION NUMBER

Figure 7. Concentrations of selected chemical constituents detected at eleven monitoring stations in subbasins that contribute water to Hobbs Brook and Stony Brook Reservoirs, eastern Massachusetts, September 1997-November 1998Continued. 


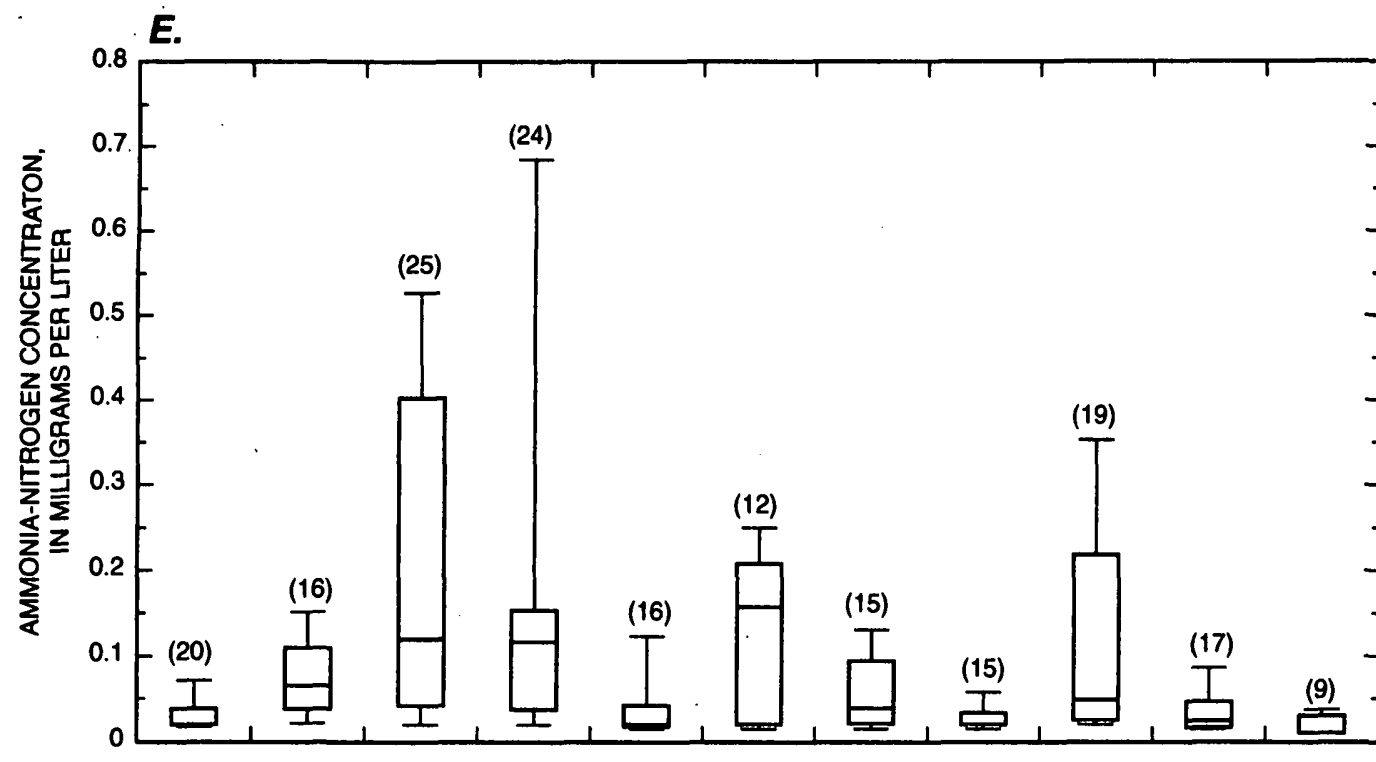

EXPLANATION

(9) NUMBER OF MEASUREMENTS

- 90th percentlie

- 75th percentile

- Median

- 25th percentile

_ 10th percentile

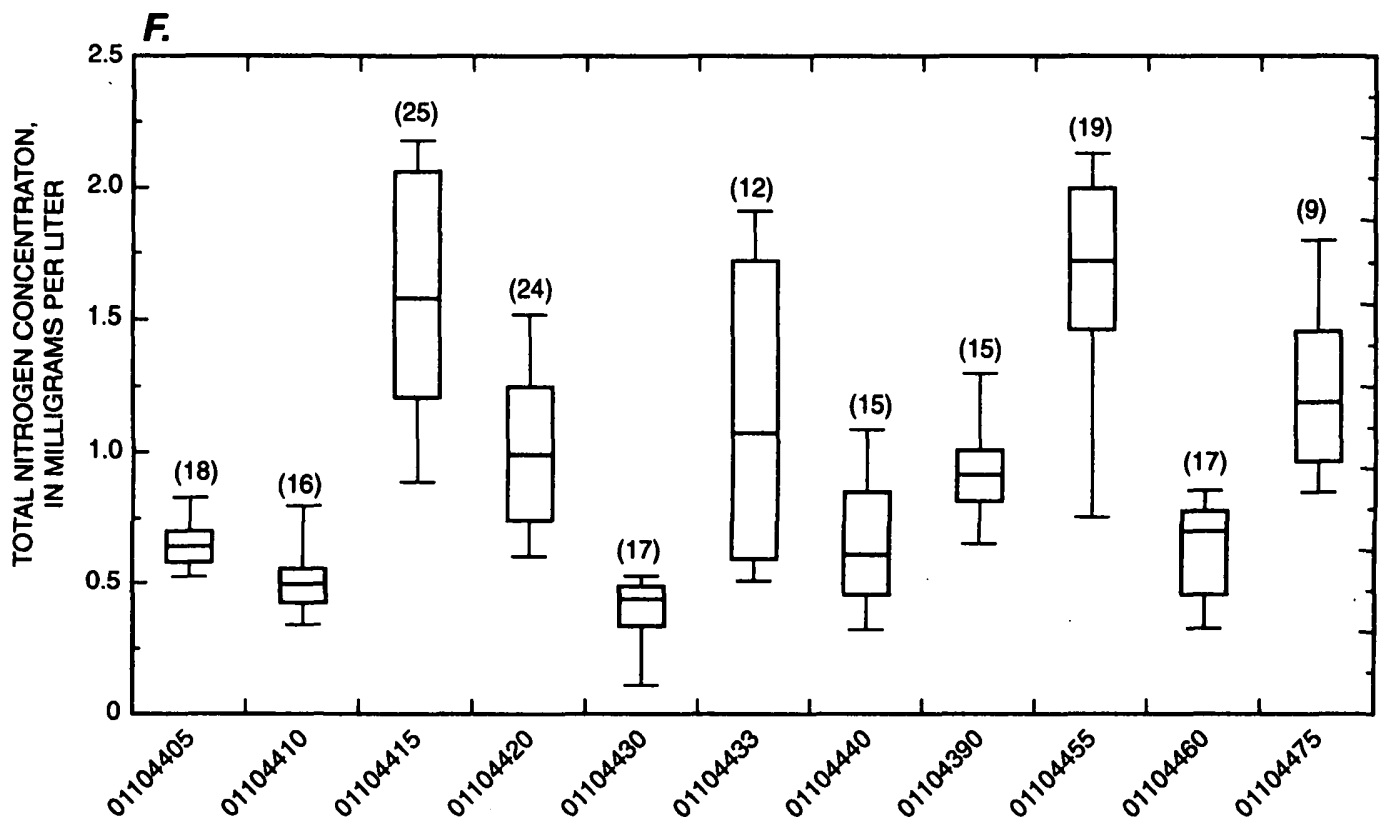

U.S. GEOLOGICAL SURVEY STATION NUMBER

Figure 7. Concentrations of selected chemical constituents detected at eleven monitoring stations in subbasins that contribute water to Hobbs Brook and Stony Brook Reservoirs, eastern Massachusetts, September 1997-November 1998-Continued. 
G.

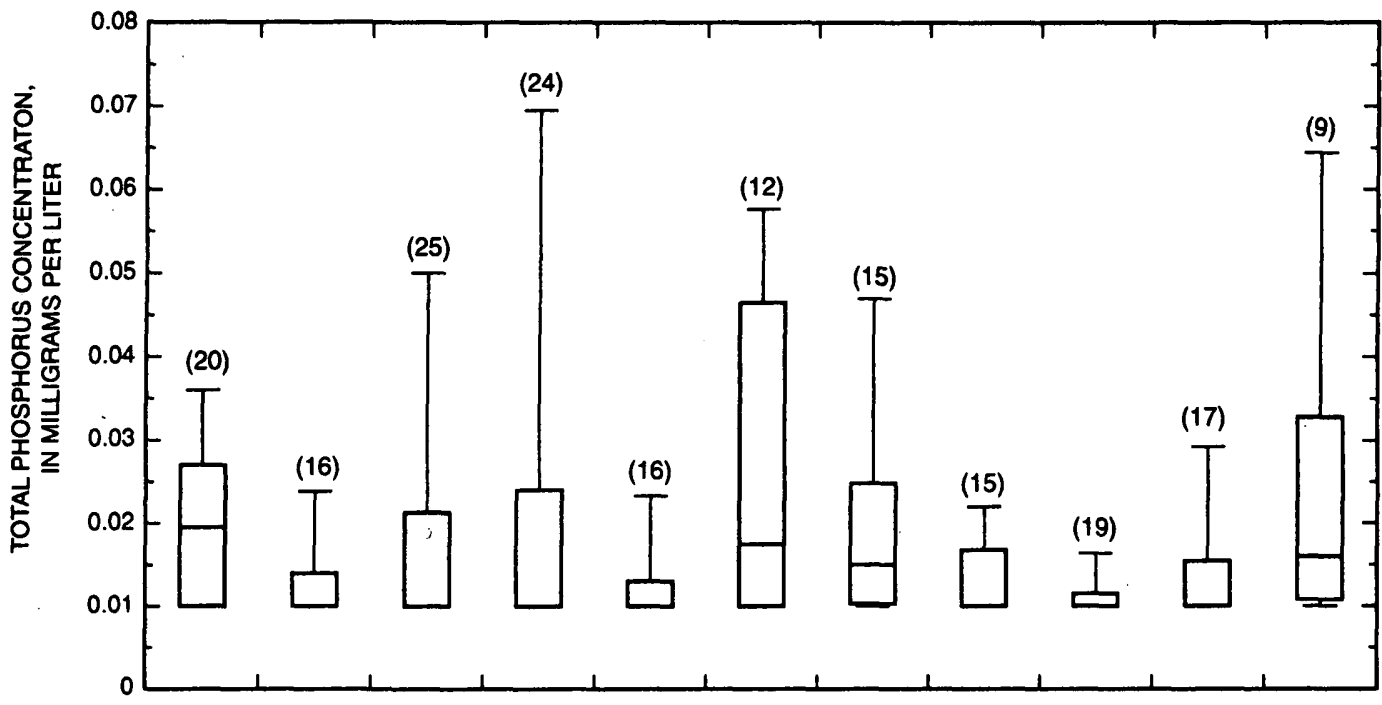

EXPLANATION

(9) NUMBER OF MEASUREMENTS

- 90th percentile

$\square$ - 75th percentile

- Median

- 25th percentile

- 10th percentile

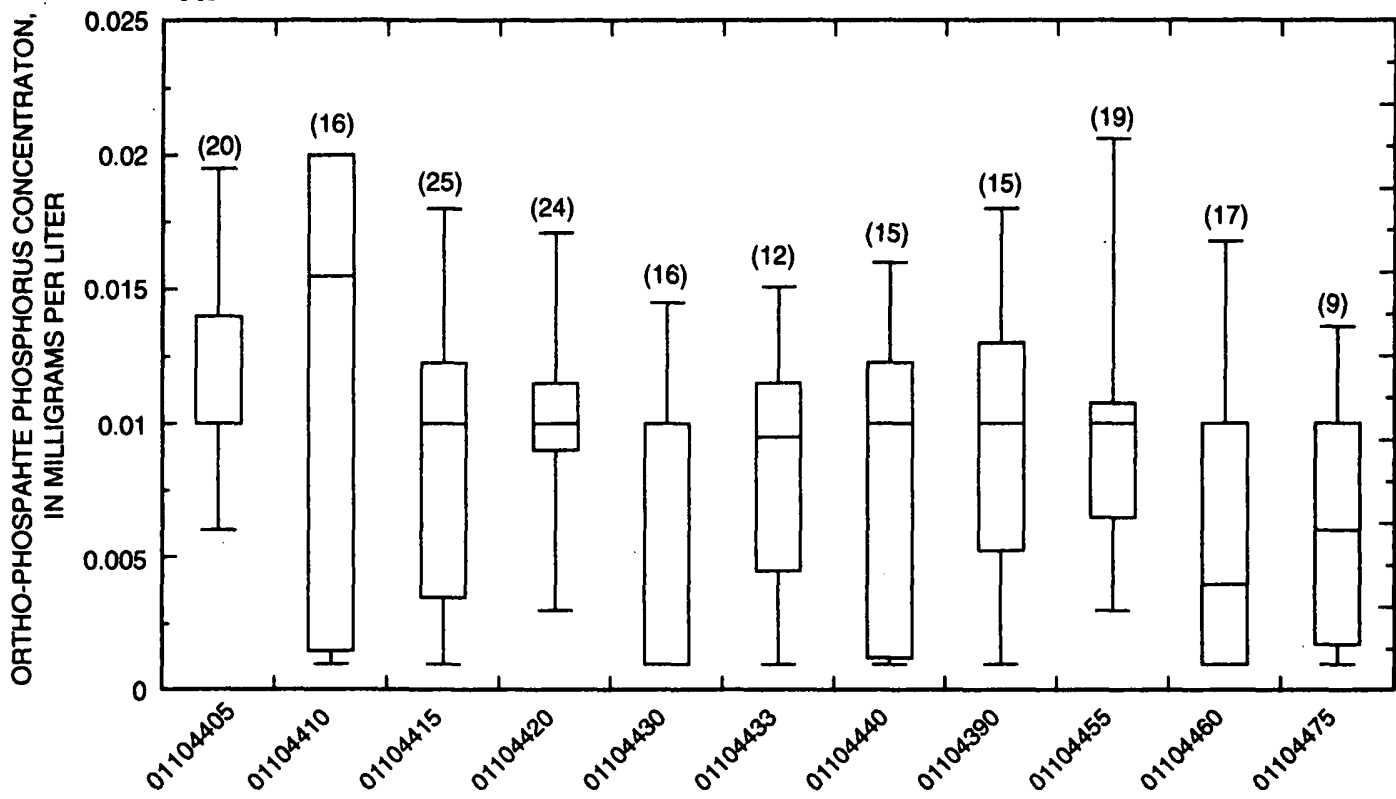

U.S. GEOLOGICAL SURVEY STATION NUMBER

Figure 7. Concentrations of selected chemical constituents detected at eleven monitoring stations in subbasins that contribute water to Hobbs Brook and Stony Brook Reservoirs, eastern Massachusetts, September 1997-November 1998Continued. 


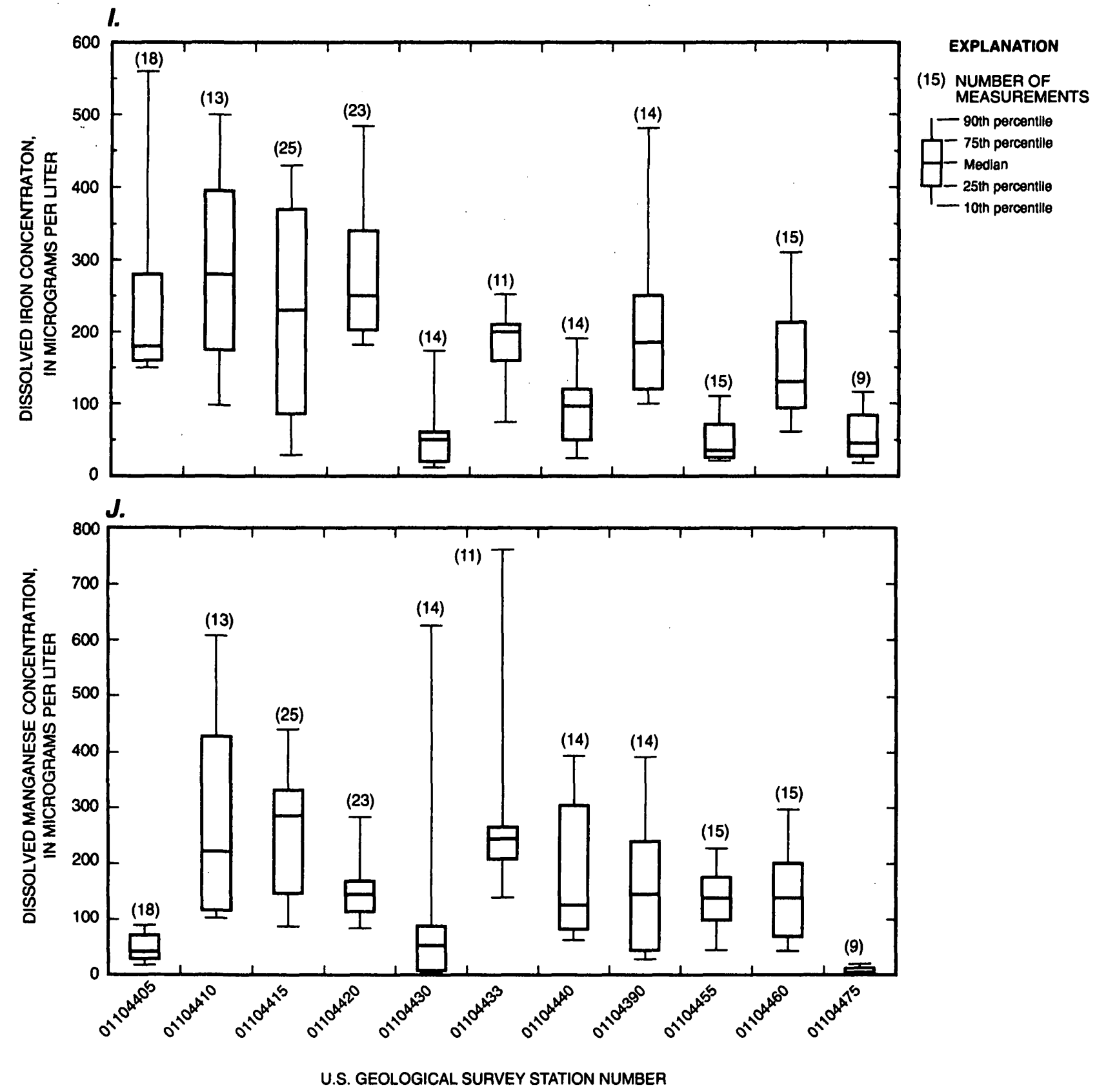

Figure 7. Concentrations of selected chemical constituents detected at eleven monitoring stations in subbasins that contribute water to Hobbs Brook and Stony Brook Reservoirs, eastern Massachusetts, September 1997-November 1998-Continued. 

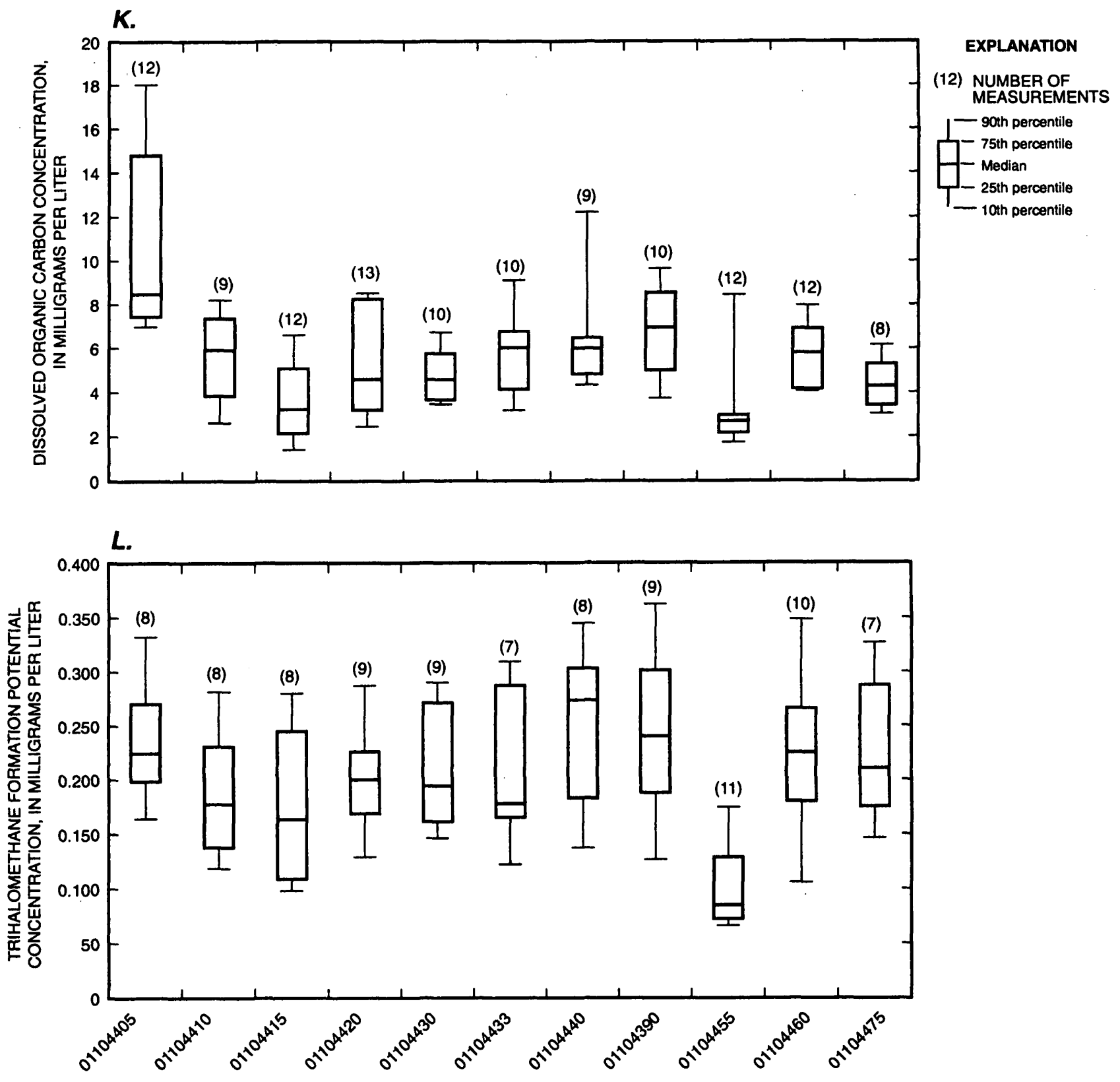

U.S. GEOLOGICAL SURVEY STATION NUMBER

Figure 7. Concentrations of selected chemical constituents detected at eleven monitoring stations in subbasins that contribute water to Hobbs Brook and Stony Brook Reservoirs, eastern Massachusetts, September 1997-November 1998-Continued. 
APPENDIX: Cambridge, Mass., Drinking Water
Source-Area Water Quality Monitoring Program 
This appendix contains a brief description of the Cambridge, Mass., drinking water source-area waterquality monitoring program. The program was designed by the U.S. Geological Survey (USGS), in cooperation with the Cambridge Water Department (CWD), and is based in part on the results of a recent (1998) assessment of reservoir and tributary-stream quality. The assessment, which was conducted jointly by the USGS and the CWD, included a detailed analysis of the drainage basin and the identification of subbasins within the drainage basin that are exporting disproportionate amounts of nonpoint pollutants. This information then was used to help the design of the monitoring network (New England Interstate Water Pollution Control Commission, 1996).

\section{Monitoring Objectives}

The process of designing a water-quality monitoring program begins with a clear definition of program goals and objectives (Reinelt and others, 1988). The goals then guide the entire process of program design and implementation. Ideally, the data obtained through monitoring provide an objective source of information needed to support management decisions. Specifically, an effective water-quality monitoring program will provide quantitative answers to the following questions (Intergovernmental Task Force on Monitoring Water Quality, 1995):

- What is the condition of the source water?

- Where, how, and why are water-quality conditions changing over time?

- What problems are related to source-water quality? Where are the problems occurring and what is causing them?

- Are programs to prevent or remediate problems working effectively?

- Are water-quality goals and standards being met?

The primary goal of the Cambridge drinking water source-area monitoring program is to ensure that water withdrawn from Fresh Pond for treatment is as free as possible from contaminants, thereby minimizing the costs of treatment. Specific objectives of the program are to

- Monitor the condition of source waters in the Cambridge drinking water supply system;

- Determine where, when, and how water-quality conditions are changing over time;

- Identify actual and potential problems related to source-water quality;

- Evaluate effectiveness of programs to prevent or remediate problems;

- Ensure that all applicable water-quality goals, standards, and guidelines are being met; and

- Provide for rapid response to emerging problems.

\section{Monitoring-Program Elements}

The Cambridge source-area monitoring program consists of four major elements: (1) routine monitoring of reservoirs and tributary streams during dry weather, (2) event-based monitoring of streams, storm drains, and other outfalls during wet weather, (3) continuous recording of stage and selected water-quality characteristics at critical sites within the drainage basin, and (4) periodic monitoring of ground water in the vicinity of Fresh Pond. The program is guided by a Quality Assurance Program Plan (QAPP, U.S. Environmental Protection Agency, 1999) that includes detailed procedures for sample collection, preparation, and analysis; program quality objectives and measurement performance criteria; and procedures for data management and evaluation.

\section{Routine (Dry Weather) Surface-Water Monitoring}

Dry-weather sampling is conducted at 3 primary and 6 secondary reservoir-monitoring stations, and at 10 primary and 6 secondary tributary-monitoring stations. The distinction between primary and secondary monitoring stations is based on the frequency of sampling and on the number of analyses performed on the samples. Locations of all monitoring stations are shown in figure $\mathrm{Al}$. 


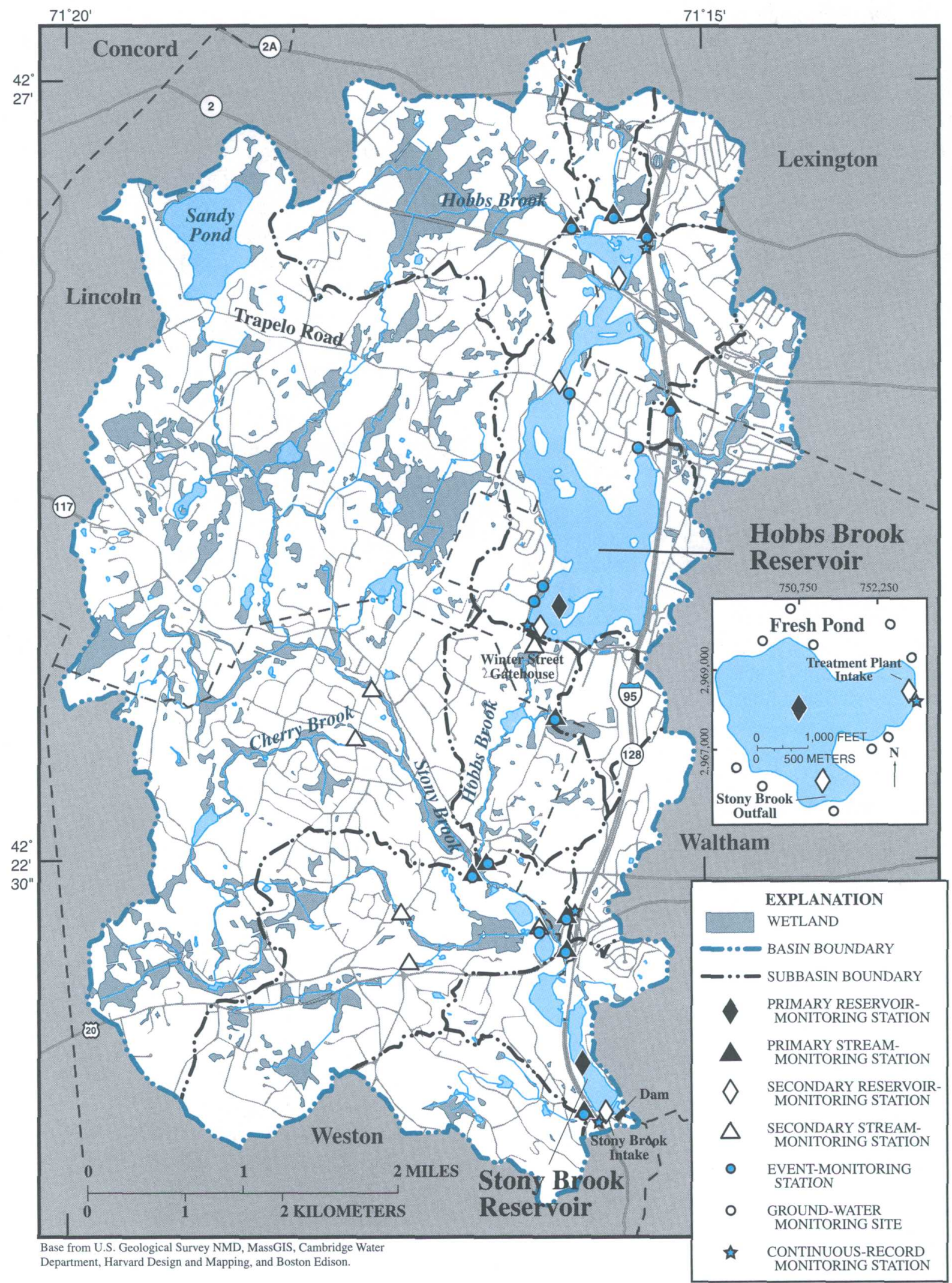

Figure A1. Cambridge, Mass., drinking-water source area water-quality monitoring network. 
At regular intervals (once each month from May through October and every other month from December through April), CWD staff measure Secchi disk transparency and depth profiles of specific conductance, $\mathrm{pH}$, water temperature, turbidity, and dissolved oxygen concentration at both the primary and the secondary reservoir-monitoring stations. The sampling schedule (table A1) is based on the results of a USGS study which determined that monthly sampling was sufficient to characterize changes in reservoir water quality during the spring, summer, and early autumn months and that sampling every other month was sufficient during winter.

Secchi disk transparency is a measure of the depth of penetration of sunlight in a reservoir. It is measured by lowering a small horizontal disk on a calibrated line and noting the depth at which it is no longer visible from the surface (Lind, 1974). In the Cambridge drinking-water source area, the Secchi disk transparency is related mainly to the abundance of phytoplankton algae in the upper mixed layers of the reservoirs. Thus, it provides a quick and inexpensive indicator of eutrophication problems. Water temperature, specific conductance, $\mathrm{pH}$, turbidity, and dissolved oxygen concentration are measured in situ with an electronic multiparameter water-quality monitoring system lowered on a cable. Depth profiles of these characteristics provide essential information on physical, chemical, and biological conditions in the reservoirs.

At the three primary reservoir-monitoring stations only (fig. A1), water samples are pumped with a peristaltic pump through pre-cleaned Tygon tubing from a depth of $6 \mathrm{ft}$ when the water column is isother$\mathrm{mal}$, or from three depths $-6 \mathrm{ft}$ below the surface, the depth of the thermocline (the point of maximum rate of change in water temperature with depth), and 2 to $6 \mathrm{ft}$ above the bottom - when the water column is thermally stratified. Water from each sampling depth is collected in accordance with clean-sampling protocols (Wilde and others, 1999) into Teflon bottles. The samples are returned to the CWD laboratory and analyzed for color, alkalinity, and concentrations of major ions (sodium, calcium, chloride, and sulfate), nutrients (ammonia nitrogen, total Kjeldahl nitrogen, nitrate nitrogen, total phosphorus, and orthophosphate phosphorus), selected metals (aluminum, iron, and manganese), and phytoplankton chlorophyll $a$, using standard methods (American Public Health Association and others, 1995). The USGS 1998 assessment of reservoir and tributary-stream quality determined that under most conditions, water-quality data collected in depth profiles at these stations are indicative of conditions throughout the reservoirs.

Color is measured spectrophotometrically and is primarily an indicator of the concentration of dissolved organic matter, which is abundant in sourcearea streams and reservoirs, and must be removed during treatment to prevent formation of organochlorine by-products. Alkalinity is a measure of the acidneutralizing capacity of a water sample and is mainly dependent on the quantities of carbonate and bicarbonate ions. The most accurate indicator of the abundance of phytoplankton algae is the amount of particulate chlorophyll $a$ in the upper mixed layer of the reservoir. Changes in chlorophyll concentrations are indicative of changes in reservoir trophic state.

Nitrogen and phosphorus are plant nutrients that can, in sufficient quantities, cause algal blooms in the reservoirs and excessive growth of algae and higher plants in the streams. Ecologically significant forms of nitrogen include ammonia and nitrate nitrogen in runoff from areas that receive fertilizer applications and in wastewater discharges, and organic nitrogen produced by microbial processes. The concentration of organic nitrogen is determined by subtracting the concentration of ammonia nitrogen from that of total Kjeldahl nitrogen.

During each round of reservoir sampling, concentrations of fecal coliform bacteria are measured at the withdrawal points in all three reservoirs (fig. A1). The presence of fecal coliform bacteria in a water sample indicates that the water may have been contaminated with feces from humans or other warm-blooded animals. Such contamination can introduce diseasecausing viruses and other potential pathogens.

Water entering the reservoirs is monitored at 10 primary and 5 secondary tributary-stream-monitoring stations (fig. A1). These stations represent streams that contribute water directly to the reservoirs and major tributaries, or integrate large areas of the drainage basin. Thus, the stations are important primary indicators of the condition of water likely to enter the reservoirs. At intervals of 2 months, the CWD measures stage and discharge and assesses water quality at each primary stream-monitoring station using USGS methods (Rantz and others, 1982; Wilde and others, 1999). The sampling frequency (table Al), in conjunction with the continuous monitors in each of the three reservoirs, is sufficient to capture changes in water quality in time to prevent contamination problems at the water-treatment plant intake. 
Table A1. Water sources, sampling frequencies, and monitored water-quality properties and constituents, for water-quality monitoring stations in the drinking-water source area for Cambridge, Massachusetts

[Monitored properties and constituents: Italicized properties and constituents are measured in the field, non-italicized properties and constituents are measured on water samples returned to the laboratory. BTX, benzene, ethylbenzene, toluene, xylenes, TPH, total petroleum hydrocarbons]

\begin{tabular}{|c|c|c|}
\hline Water source(s) & Sampling frequency & Monitored properties and constituents \\
\hline \multicolumn{3}{|c|}{ Routine (Dry-Weather) Surface-Water Monitoring } \\
\hline $\begin{array}{l}\text { Primary reservoir-monitoring stations (3) at the deepest } \\
\text { points in Hobbs Brook Reservoir, Stony Brook } \\
\text { Reservoir, and Fresh Pond }\end{array}$ & 9 depth profiles per year & $\begin{array}{l}\text { Specific conductance } \\
\text { pH } \\
\text { Water temperature } \\
\text { Color } \\
\text { Turbidity } \\
\text { Secchi disk transparency } \\
\text { Dissolved oxygen concentration } \\
\text { Major ions } \\
\text { Alkalinity } \\
\text { Nutrients } 2 \\
\text { Selected metals } \\
\text { Phytoplankton chlorophyll } a\end{array}$ \\
\hline $\begin{array}{l}\text { Secondary reservoir-monitoring stations (6) in the } \\
\text { upper and middle basins of Hobbs Brook Reservoir, } \\
\text { at the Winter Street Gatehouse, the intakes at Stony } \\
\text { Brook Reservoir and Fresh Pond, and the outfall } \\
\text { from Stony Brook Reservoir in Fresh Pond }\end{array}$ & 9 depth profiles per year & $\begin{array}{l}\text { Specific conductance } \\
\text { pH } \\
\text { Water temperature } \\
\text { Color } \\
\text { Turbidity } \\
\text { Secchi disk transparency } \\
\text { Dissolved oxygen concentration } \\
\text { Fecal coliform bacteria } 4\end{array}$ \\
\hline Primary tributary-stream-monitoring stations (10) & 6 times per year & $\begin{array}{l}\text { Stream stage and discharge } \\
\text { Specific conductance } \\
\text { pH } \\
\text { Water temperature } \\
\text { Color } \\
\text { Turbidity } \\
\text { Dissolved oxygen concentration } \\
\text { Fecal coliform bacteria } \\
\text { Major ions }{ }^{1} \\
\text { Alkalinity } \\
\text { Total suspended solids } \\
\text { Nutrients } \\
\text { Selected metals }^{3}\end{array}$ \\
\hline Secondary tributary-stream-monitoring stations (6) & 2 times per year & $\begin{array}{l}\text { Stream stage and discharge } \\
\text { Specific conductance } \\
\text { pH } \\
\text { Water temperature } \\
\text { Color } \\
\text { Turbidity } \\
\text { Dissolved oxygen concentration } \\
\text { Fecal coliform bacteria } \\
\text { Major ions } \\
\text { Alkalinity } \\
\text { Total suspended solids } \\
\text { Nutrients } \\
\text { Selected }^{2} \\
\text { metals }\end{array}$ \\
\hline
\end{tabular}


Table A1. Water sources, sampling frequencies, and monitored water-quality properties and constituents, for water-quality monitoring stations in the drinking-water source area for Cambridge, Massachusetts-Continued

\begin{tabular}{|c|c|c|}
\hline Water source(8) & Sampling frequency & Monitored propertles and constituents \\
\hline \multicolumn{3}{|c|}{ Event-Based (Wet-Weather) Surface-Water Monitoring } \\
\hline $\begin{array}{l}\text { Tributary-monitoring stations (9), storm drains (2), and } \\
\text { other outfalls (4) in the drainage basin }\end{array}$ & $3-5$ storms per year & $\begin{array}{l}\text { Specific conductance } \\
\text { pH } \\
\text { Water temperature } \\
\text { Color } \\
\text { Turbidity } \\
\text { Dissolved oxygen concentration } \\
\text { Fecal coliform bacteria } \\
\text { Major ions } \\
\text { Alkalinity } \\
\text { Total suspended solids } \\
\text { Nutrients } \\
\text { Selected metals }\end{array}$ \\
\hline \multicolumn{3}{|c|}{ Continuous-Record Surface-Water Monitoring } \\
\hline $\begin{array}{l}\text { Two primary tributary-monitoring stations and three } \\
\text { secondary reservoir-monitoring stations }\end{array}$ & 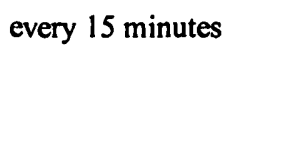 & $\begin{array}{l}\text { Stage } \\
\text { Water temperature } \\
\text { Specific conductance } \\
\text { Precipitation }{ }^{5}\end{array}$ \\
\hline \multicolumn{3}{|c|}{ Ground-Water Monitoring } \\
\hline $\begin{array}{l}\text { Ground-water-monitoring wells in the vicinity of Fresh } \\
\text { Pond }\end{array}$ & 2 times per year & $\begin{array}{l}\text { Specific conductance } \\
\text { pH } \\
\text { Water temperature } \\
\text { Color } \\
\text { Turbidity } \\
\text { Dissolved oxygen concentration } \\
\text { Fecal coliform bacteria } \\
\text { Major Ions } \\
\text { Alkalinity } \\
\text { Total Suspended Solids } \\
\text { Nutrients }{ }^{2} \\
\text { Selected metals } \\
\text { Trace metals } \\
\text { TPH } \\
\text { BTX }\end{array}$ \\
\hline
\end{tabular}

${ }^{\mathrm{I} C a l c i u m, ~ s o d i u m, ~ s u l f a t e, ~ c h l o r i d e . ~}$

${ }^{2}$ Ammonia nitrogen, total Kjeldahl nitrogen, nitrate nitrogen, total phosphorus, orthophosphate phosphorus.

${ }^{3}$ Aluminum, iron, manganese.

${ }^{4}$ Measured only at the Winter Street Gatehouse and at the intakes in Stony Brook Reservoir and Fresh Pond.

${ }^{5}$ Measured at two continuous-record monitoring stations only.

${ }^{6}$ Arsenic, barium, cadmium, chromium, lead, mercury, nickel, selenium, silver . 
Specific conductance, $\mathrm{pH}$, water temperature, turbidity, and dissolved oxygen concentration are measured on site and water samples are collected using clean-sampling protocols (Wilde and others, 1999) into 1-liter Teflon isokinetic samplers. Discharge-weighted, representative samples are collected from multiple vertical profiles distributed at equal distances along stream cross sections (Edwards and Glysson, 1999). The samples are then returned to the CWD laboratory for analysis of color, fecal coliform bacteria, alkalinity, total suspended solids, and concentrations of major ions, nutrients, and selected metals (table A1).

The five secondary stream-monitoring stations are monitored twice a year, usually during base flow and high flow. These stations are located higher up in the drainage basin on smaller tributaries or at points that discharge to the reservoirs predominantly during wet weather (fig. Al). The secondary stations are sampled biannually for the same constituents as the primary stations to provide indicators of potential changes in water quality or of base-flow conditions. Each round of periodic sampling includes quality-assurance samples (field and instrument blanks, duplicates, and sample splits) representing about 10 percent of the total number of samples analyzed.

\section{Event-Based (Wet Weather) Surface-Water Monitoring}

Storm-event sampling is conducted three to five times each year at a number of event-monitoring sites, some of which are primary and secondary streammonitoring stations and some of which are pipes and culverts that discharge to the reservoirs (fig. A1). The goal of the storm-event sampling is to collect samples of the first flush of runoff from storms producing 0.5 inches or more of rain following a period of at least 3 days of dry weather. This goal is accomplished by deploying passive samplers consisting of acid-washed polypropylene bottles with caps that fill automatically when the stream stage reaches a predetermined level or by manually collecting the first flush from pipes or culverts. The water samples are retrieved within 6 hours after the storm ends and are analyzed for color, fecal coliform bacteria, alkalinity, total suspended solids, and concentrations of major ions, nutrients, and selected metals.

\section{Continuous-Record Surface-Water Monitoring}

Continuous ( 15 minute interval) monitoring is contucted at two primary tributary-monitoring stations and three secondary reservoir-monitoring stations (fig. Al). These stations are operated and maintained by the USGS and the CWD for continuous measurement of stream and reservoir stage and temperaturecorrected specific conductance. Specific conductance, a measure of the ability of the water to conduct an electrical current, is an indicator of the concentrations of dissolved electrolytes in the water. The stations at Hobbs Brook Reservoir and Stony Brook Reservoir also monitor stage and specific conductance of the discharges from the reservoirs. The continuous streamstage data are converted to discharge by the use of stage-discharge relations (Rantz and others, 1982) and the specific conductance records are converted to concentrations of sodium, calcium, and chloride in a similar fashion (Granato and Smith, 1999).

\section{Ground-Water Monitoring}

The quality of ground water in the area around Fresh Pond is assessed twice each year at monitoring wells (fig. Al). Water samples are collected using a stainless-steel submersible pumping system with Tygon tubing. The water is pumped slowly through a chamber for measurement of specific conductance, $\mathrm{pH}$, water temperature, turbidity, and dissolved oxygen concentration. When conditions stabilize, the data are recorded, and water samples are collected for analysis of fecal coliform bacteria, alkalinity, total suspended solids, and concentrations of major ions, nutrients, major ions, trace metals (aluminum, iron, manganese, arsenic, barium, cadmium, chromium, lead, mercury, 
selenium, silver, nickel), total petroleum hydrocarbons, and BTX (benzene, ethylbenzene, toluene, total xylenes).

\section{Data Management, Interpretation, Reporting, and Review}

The monitoring and quality-assurance data are entered into a data base, maintained by the CWD as part of a Watershed Management Tool, that enables the CWD to efficiently map, plan, track, and report drainage-basin management and water-quality monitoring activities. Monitoring is conducted by a hydrologic technician and an assistant (Reservoir Caretaker). USGS methods and protocols are used in the program so that results may be compared to baseline data collected by the USGS during water year 1998. The entire program is reviewed periodically by a Technical Advisory Committee that includes members from the Cambridge academic community, and a Watershed Advisory Committee comprised of representatives from Cambridge, Waltham, Weston, Lexington, and Lincoln.

The CWD also conducts special investigations of water-quality related problems and situations within the source area. Such investigations may include intensive monitoring at present water-quality monitoring stations indicating increasing trends in contaminant loading, monitoring at locations where known disturbance is taking place, and monitoring to assess the effectiveness of new management practices or infrastructure. These investigations frequently require analysis of a variety of constituents and water-quality related properties.

\section{References Cited}

American Public Health Association, American Water Works Association, and Water Pollution Control Commission, 1995, Standard methods for the examination of water and wastewater (19th ed.): Washington, D.C., APHA, variously paginated.
Edwards, T.K., and Glysson, G.D., 1999, Field methods for measurement of fluvial sediment: U.S. Geological Survey Techniques of Water-Resources Investigations, chap. $\mathrm{C} 2$, book 3, $89 \mathrm{p}$.

Granato, G.E., and Smith, K.P., 1999. Estimating concentrations of road-salt constituents in highway runoff from measurements of specific conductance: U.S. Geological Survey, Water-Resources Investigations Report 99-4077, 22 p.

Intergovernmental Task Force on Monitoring Water Quality, 1995, The strategy for improving water-quality monitoring in the United States-Final report of the Intergovernmental Task Force on Monitoring Water Quality: Reston, Va., U.S. Geological Survey Office of Water Data Coordination, 25 p. plus Appendixes.

Lind, O.T., 1974, Handbook of common methods in limnology: St. Louis, The C.V. Mosby Co., 145 p.

New England Interstate Water Pollution Control Commission, 1996, Source protection. A guidance manual for small surface water supplies in New England: New England Interstate Water Pollution Control Commission, 77 p. plus Appendices.

Rantz, S.E., and others, 1982, Measurement and computation of streamflow-Volume 1. Measurement of stage and discharge-Volume 2. Computation of discharge: U.S. Geological Survey Water-Supply Paper $2175,631 \mathrm{p}$.

U.S. Environmental Protection Agency, 1999, Region I, EPA-New England Compendium of Quality Assurance Project Plan Requirements and Guidance: U.S. EPANew England, Region I, Office of Environmental Measurement and Evaluation, variously paginated.

Wilde, F.D., Radtke, D.B., Gibs, Jacob, and Iwatsubo, R.T., 1999 , Collection of water samples, National field manual for the collection of water-quality data: U.S. Geological Survey Techniques of Water-Resources Investigations, book 9, chap. A4, $103 \mathrm{p}$. 